\title{
Kernos
}

Revue internationale et pluridisciplinaire de religion grecque antique

$26 \mid 2013$

Varia

\section{Epigraphic Bulletin for Greek Religion 2010 (EBGR 2010)}

\section{Angelos Chaniotis}

\section{OpenEdition \\ Journals}

Electronic version

URL: http://journals.openedition.org/kernos/2216

DOI: 10.4000/kernos.2216

ISSN: 2034-7871

\section{Publisher}

Centre international d'étude de la religion grecque antique

Printed version

Date of publication: 10 October 2013

Number of pages: 241-302

ISSN: 0776-3824

\section{Electronic reference}

Angelos Chaniotis, "Epigraphic Bulletin for Greek Religion 2010 (EBGR 2010)", Kernos [Online], 26 |

2013, Online since 01 October 2014, connection on 02 March 2021. URL: http://

journals.openedition.org/kernos/2216 ; DOI: https://doi.org/10.4000/kernos.2216 
Kernos 26 (2013), p. 241-302.

\section{Epigraphic Bulletin for Greek Religion 2010 (EBGR 2010)}

The 23rd issue of the Epigraphic Bulletin for Greek Religion presents a selection of the epigraphic publications of 2010 and additions to earlier issues (especially publications of 2008 and 2009). As usual, emphasis was placed on the presentation of editions of new texts. This issue contains several interesting new epigraphic finds, mostly from Asia Minor. I would like to highlight a long Hellenistic inscription from Lykia (Tlos or Xanthos) that concerns a funerary foundation (143); besides providing interesting details regarding the sacrifice and the banquet, this text is an important piece of evidence for the devotion of an individual to a personal patron god (Helios, in this case), for belief in a personal 'hero' (or daimon), and the heroization through private initiative. A decree from Nysa provides valuable information about the exploitation of offering tables by trapezonai in a sanctuary of Plouton and Kore (54, 1st cent. CE). Two Hellenistic inscriptions from the area of Pergamon (129) make known a sanctuary of Asklepios, where incubation was practiced; one text commemorates the foundation of a cult association for the worship of Asklepios consisting of soldiers; the other is a purity regulation for those who entered the sanctuary. Undoubtedly, the most puzzling document is a Hellenistic honorary decree from Halaisa (116 and 177) which attests to an 'assembly of priests' and the 'koinon of the priests of Apollo'; 825 votes were cast in favour of the decree during an assembly of the priests. One can only speculate about the nature of this association of 825 priests. Other new inscriptions include attestations of the cult of the Proimoi Theoi who were probably perceived as patrons of fertility in Lykia (41, 2nd cent. BCE); this property can also be assumed for Poseidon and the Nymphs, to whom an interesting epigram was dedicated in Kibyra (42, 2nd cent. CE). A group of dedications to Zeus Ombrimos, Hera Basilissa, and Poseidon Kyanochaites from Tropaeum Traiani in Moesia (12, 3rd cent. CE) have archaising features that may be attributed to education and literary interests. In a new fragmentary oracle from Didyma, Apollo instructs that hymns be sung in the worship of the Horai, the mothers of the Hopes (205, 3rd cent. $\mathrm{CE}$ ); this oracle may be connected with a general tendency that has been observed in the Imperial period to give priority to hymnody over sacrifice. Evidence for ideas about the afterlife is provided in a collection of funerary epigrams from south and central Greece (29). As regards the association of the divine with notions of justice and punishment - an idea that manifests itself inter alia in dedications, confessions, and 'prayers for justice' (for which see 199) - I single out two studies of the way in which the justice of the gods was assimilated to secular justice (95; cf. EBGR 2009, 33) and of how in defixiones the prosecution of an opponent by means of a curse may be formally likened to actual prosecution (43). In the domain of magic, a gemstone from the Black Sea may be a miniature handbook for the making of amulets expected to guard against various head diseases (56). A significant contribution to the thriving research on the Dionysiac-Orphic texts is the publication of a corpus of the Cretan texts (196), including a new variant of the formula 'but give me to drink from the spring' which may be associated with the cult in the 
Idaean Cave. I also note a reconstruction of the Ionic original on which the Hipponion text may have been based (65), as well as the proposed distinction between those who performed Orphic rituals (mystai) and those who internalized the values of the DionysiacOrphic cult and lived a life in accordance with its precepts, thereby posthumously attaining a permanent state of holiness in union with Dionysos (85).

The principles explained in Kernos 4 (1991), p. 287-288, and Kernos 7 (1994), p. 287, also apply to this issue. Abbreviations that are not included in the list are those of L'Année Philologique and J.H.M. STRUBBE (ed.), Supplementum Epigraphicum Graecum. Consolidated Index for Volumes XXXVI-XLV (1986-1995), Amsterdam, 1999, as well as of later volumes of the SEG. If not otherwise specified, dates are BCE. Michael Anthony Fowler (Columbia University) has improved the English text.

\section{Abbreviations}

Dediche sacre

J. Bodel - M. Kajava, (eds.), Dediche sacre nel mondo grecoromano. Diffusione, funzioni, tipologie. Religious Dedications in the GrecoRoman World. Distribution, Typology, Use. Institutum Romanum Finlandiae. American Academy in Rome 19-20 aprile, 2006, Rome, 2009.

Festrituale

J. RÜPKE (ed.), Festrituale: Diffusion und Wandel im römischen Reich, Tübingen, 2008.

From Mesogeia to Argosaronikos

V. VAssilopoulou - S. Katsarou-TZEVEleKI (eds.), From Mesogeia to Argosaronikos. B' Ephorate of Prehistoric and Classical Antiquities: Research of a Decade, 1994-2003. Proceedings of a Conference. Athens, December 18-20, 2003, Markopoulo, 2009.

Greek and Roman Networks

I. MALKIN - C. Constantakopoulou - K. PANAgOpoulou (eds.), Greek and Roman Networks in the Mediterranean, London, 2009.

Greek History and Epigraphy L. MitCHELL - L. RUBINSTEIN (eds.), Greek History and Epigraphy. Essays in Honour of P.J. Rhodes, Swansea, 2009 [presented in part in EBGR 2009].

Identität und Zugehörigkeit

A. CoşKun - H. HeINen - S. Pfeiffer (eds.), Identität und Zugebörigkeit im Osten der griechisch-römischen Welt. Aspekte ibrer Repräsentation in Städten, Provinzen und Reichen, Frankfurt, 2009.

Kermatia - Touratsoglou

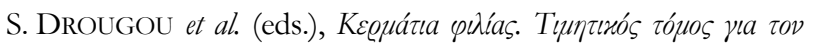
I wávvi Tov@átoojiou, Athens, 2009.

Mystic Cults in Magna Graecia G. CASADIO - P.A. Johnston (eds.), Mystic Cults in Magna Graecia, Austin, 2009.

Paysage et religion P. CARLIER - C. LeROUGE-COHEN (eds.), Paysage et religion en Grèce antique, Paris, 2010.

Philathenaios

A. TAmis - C. J. MacjIE - S. G. Byrne (eds.), Philathenaios. Studies in Honour of Michael J. Osborne, Athens, 2010.

Religion des Imperium Romanum H. CANCIK - J. RÜPKE (eds.), Die Religion des Imperium Romanum. Koine und Konfrontationen, Tübingen, 2009.

Ritual Dynamics

O. HEKSTER - S. SCHMIDT-HOFNER - C. WiTSCHEL (eds.), Ritual Dynamics and Religious Change in the Roman Empire. Proceedings of the Eighth Workshop of the International Network Impact of Empire (Heidelberg, July 5-7, 2007), Leiden, 2009. 
Synedrio Boiotikon Meleton IV

Temi selinuntini

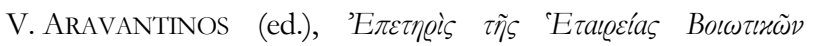

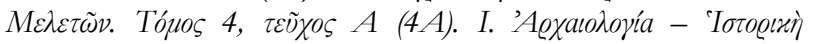

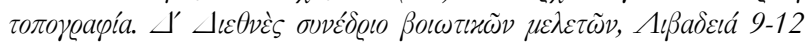
$\sum \varepsilon \pi \tau \varepsilon \mu \beta \varrho i o u ~ 2000$, Athens, 2008.

C. AntonetTi - S. De Vido (eds.), Temi selinuntini, Pisa, 2009.

\section{Selected Topics}

Geographical areas (in the sequence adopted by SEG)

Attica: 1. 88-90. 148; Athens: 19. 29. 52. 81. 82. 92. 101. 107. 111. 114. 120. 123. 126.127. 153. 171. 204. 206; Eleusis: 24. 137; Piraeus: 201; Rhamnous: 185. Peloponnese: Aigina: 121. Corinthia: Corinth: 29; Isthmia: 82. Kleonaia: Nemea: 123. Argolis: Argos: 155. 157. 206. Troizenia: 66; Kalaureia: 203. Lakonia: 64; Sparta: 82. Messenia: Andania: 153. 155. 190-192; Messene: 11. 190-192. Arkadia: Lykaion, Mt.: 108; Megalopolis: 29. Elis: 145; Olympia: 82. 108. 109. 162. Kythera: 195. Megaris: Megara: 164. Boiotia: 9. 82. 96. 106. 206; Akraiphia: 35. 82. 118. 182; Lebadeia: 118; Leuktra: 156; Orchomenos: 82. 118; Oropos: 90. 118. 171; Plataia: 82; Tanagra: 20. 118; Thebes: 8. 118; Thespiai: 96. 118. Delphi: 47. 75. 80. 82. 92. 108. 147. 151. 186. 206. Eastern Lokris: Opous: 186. Aitolia: 145. Akarnania: Thyrrheion: 29. 82. Ionian Islands: Ithaka: 28. Thessaly: 29. 62. 71. 106; Larisa: 76. 77. Epeiros: Dodona: 199. Macedonia: 40. 179. 180; Amphipolis: 115; Ano Komi Kozanis: 207; Beroia: 71. 78. 202; Dion: 152; Lete: 71; Philippi: 100; Pontokomi: 91; Serrai: 131; Thessalonike: 4. 78. 130. 183. Thrace: 99; Anchialos: 43. 72. 146. Moesia: Histria: 45; Kallatis: 13; Nikopolis: 178; Tomis: 12; Tropaeum Traiani: 11. Dacia: 30. North Shore of the Black Sea: Chersonesos in Tauris: 45; Gorgippeia: 56; Olbia: 45. 193; Pantikapaion: 57. Delos: 101. 126. 206. Rhodes: 10. 113. 206. Lesbos: Methymna: 153. Kos: 93. 162. 163. 197. Kalymnos: 21. Paros: 100. 137. Keos: 124. 206. Andros: 149. Chios: 169. 206. Samos: 194. 200. Amorgos: 106. 199. Peparethos: 50. Samothrake: 200. Thasos: 93. 100. 137. Euboia: 96; Amarynthos: 206; Eretria: 96. 97; Oreoi: 102. Crete: 173. 196; Gortyn: 140; Idaean Cave: 196; Lyttos: 139. Italy: Hipponion: 65; Kyme: 31; Rome: 123. Sicily: 117; Halaisa: 116. 177; Selinous: 7. 15. 43. 72. 43. 72. 146; Syracuse: 206. Sardinia: Olbia: 16. Germania: 18. Britain: 95. Asia Minor: 58. 128. Karia: Aphrodisias: 34. 39. 150; Apollonia of Salbake: 58; Knidos: 93. 199; Nysa: 54. Ionia: Didyma: 132. 205; Ephesos: 82. 140. 172; Klazomenai: 22; Klaros: 48. 132; Kolophon: 48; Magnesia on the Maeander: 154; Miletos: 163. Lydia: 160. 161; Attaleia: 181; Daldis: 181; Ioulia Gordos: 181; Sardes: 162. Troas: Alexandreia/Troas: 86; Lampsakos: 86. Mysia: Gambreion: 153; Pergamon: 129. Bithynia: Kalchedon: 164. Pontus: Sinope: 45. 60. 119. Paphlagonia: 184. Phrygia: 79; Aizanoi: 158. 189; Hierapolis: 84; Motylla: 5. Pisidia: 133-134; Antiocheia: 14. 105. 125. 136; Diokaisareia: 135; Sagalassos: 112. Pamphylia: 67; Perge: 168. Lykia: 136. 174; Boubon: 58; Kibyra: 42; Melanippion: 3; Myra: 41; Patara: 53. 167. 175; Phellos: 176; Sidyma: 187; Termessos: 32. 33; Tlos: 143; Xanthos: 68. 143. 167. Kilikia: Diokaisareia: 166. Cyprus: 82. 173; Paphos: 38; Salamis: 206. Syria: 25. 26. Damaskos: 6; Gerasa: 63; Heliopolis: 103. Palaestina: 173. Egypt: 23. 38. 73. 170. 173; Naukratis: 73. 100. Kyrenaika: Kyrene: 17. 108. 138

abortion: 129

acclamation: 35. 36; see also Greek words

accounts: 19. 101. 107. 118. 120

afterlife: 29. 125. 127. 150. 181; see also Greek words

agency, ritual: 37

alphabetical oracle: 84 
altar, shared by gods: 144

amphiktyony, Delphic: 47. 80. 108. 151. 186; of Zeus Lykaios: 108

amulet: 55. 56. 117. 122; uterine: 46

anatomical votive: 39

angel: 125

animal: eagle: 39; sacrificial: ewe: 42; goat: 42. 143; pig: 1. 143; sheep: 143

apotropaic text: 56; see also Greek words

archaism: 13

association, cult: 14. 35. 113. 129. 178. 183; Dionysiac artists; 38. 151; see also Greek words asylia: 37

banquet: 7.14.35. 94. 105. 143. 182; facilities for: 34. 111; funerary: 77

bath, ritual: 71

benefactor: 34 . 35. 54. 155. 182; cult of: 126

birthday: 131; of emperor: 78

burial: 181; intra muros: 34; cenotaph: 150; tax: 165

cake, sacrificial: 1

cession of property to a god: 37

Christianity: 55. 117; and paganism: 184

coins, minted for festivals: 22

commemorative ritual: 143

communication: 36.87

Compitalia: 37

confession inscription: 104. 142. 199

contest: 26.27 .35 .108 .113 ; choral: 96; musical: 61. 118. 206; privileges of victors: 165 ; prizes: 147; see also s.vv. festival, torch race

crowning: 1; of a god: 171

cry, ritual: 36

cult, foundation of: 129; introduction of: 106. 126. 143. 183; reform: 155; transfer of: 6. 14. 24. 45. 100. 104. 137; ; see also Greek words

cult of mortals: Archilochos: 137; benefactor: 126; Roman magistrates: 128; senatus: 128 ; see also imperial cult, ruler cult

cult personnel: agonothetes: 78. 118; amphiktyones: 108; archiereus, of the provincial imperial cult in Lykia: 176; in Macedonia: 78; chresmologos: 82; epispondorchestes: 82; hageter theon: 190; hellanodikai: 108; hiereia (priestess): 1. 20. 101; hiereus (priest): 10. 20. 32. 33. 39. 41. 94. 116. 140. 168. 177. 178; hiereus pro poleos: 41. 167. 175. 176; hieromnemon: 108; hieropoios: 197; hierophantes: 155; hieros: 155. 190; hieroskopos: 82 ; hierothytes: 175 ; kanephoros: 92; Karneiastas: 155. 190; mantiarches: 82; mantis: 82; melopoios: 206; oionoskopos: 82; pronoetes hierou: 170; prophetes: 82. 164. 205; prospolos: 190; rhapsodos: 206; sebastophoros: 53; stephanephoros: 124; theokolos: 82; theologos: 206; theopropos: 82; thytes: 82.141 ; cult personnel, family of: 82 ; for life: 41.82 ; iteration: 78 ; remunaration of: 1 ; social position: 82. 92. 190; see also s.v. priesthood

cult regulation: 1. 29. 93. 110. 129. 142. 153. 155. 190; metrical: 196

curse, cursing: 95. 121. 123. 134. 143. 174. 199; doll: 123; see also s.vv. defixio, funerary imprecation and Greek words

dance: 35 
death: 129; see also s.v. afterlife

dedication: 16. 54. 75; administration of: 110; protection of: 110; removal of: 110

dedication, object of: clothes: 204; cymbal: 64; fibula: 64; human being: 5; literary work: 97 ; torch: 101; writing exercise: 195; see also s.v. anatomical votive and Greek words

dedication, agent of: freedman: 63.149; magistrate: 197; officer: 173; police officer: 58; priest: 39. 94. 197; priest after his term in office: 69. 197; soldier: 166; victor: 118

dedication, motives for: well-being of emperor: 138; fulfilment of vow: 13. 33. 39. 63. 67. 68. 79. 105. 134. 136. 189. 207; in gymnasion: 44. 97 ; on behalf of a family member: 39 . 189; upon divine command: 5. 23. 39. 87; see also Greek words

defixio: 10. 15. 16-18. 43. 81. 121. 148. 193. 199; influence of public documents on defixiones: 43; lamps used for d.: 123

deities: Aphrodite: 34. 39. 49. 55. 88. 89. 103. 152. 183. 190. 195; Epilimenia 49; Epiteuxidia 183; Euploia 49; Hilara 38; Kynegetis 67; Ourania 34; Pandemos 34; Paphie 38; Pergaia 67; Pontia 49. Apollo: 21. 38. 40. 44. 62. 68. 82. 84. 92. 116. 124. 132. 138. 147. 161. 177; Chresterios 164; Epikomaios 100; Epikomios 100; Hismenios 8; Ietros 45; Karneios 190; Klarios 48. 87; Komaios 100; Lairbenos 5; Lykeios 50; Phoibos 55; Platanistas 66; Ptoios 82; Pythaios 155. 164; Pythios 47. 88. 89. 164. Archegetes: 1. Ares: 6. 58. 99. Artemis: 1. 32. 36. 68. 100. 157. 168. 190; Agrotera 207; Akraia 33. 62; Aspalis 33. 62; Aspalos 33; Brauronia 204; Chthonia 148; Ephesia 40. 161; Kelbessis 32; Kolainis 88; Lenkophryene 154; Limnatis 64. 191; Mounychia 201; Throsia 62. 71. Asklepios: 36. 39. 111. 113. 129. 138. 179. 195. Athena: 3. 40. 152. 166; Itonia 106. Brimo: 62. Charites: 38. 82. 126. Demeter: 29. 109. 137. 152; Archis 71; Chamyne 109; Chloe 1; Eleusinia 1. 24. 137; Malophoros: 43. 72. 146. Demos: 126. Dionysos: 6. 29. 31. 33. 40. 45. 52. 96. 176. 183. 202; Agrios 71; Anthios 1; Erikryptos 71; Gongylos 183; Prinophoros 183; Pseudanor 71. Dioskouroi: 11. 67. Eileithyia: 152. 191. Elpides: 205. Ennodia: 40. 91; Ilias 77; Koroutarra 62. 77; Mykaika 77; Pheraia 201; Stropika 77. Erinyes: 125. Hades: 29. Hagna: 155. Hagne Theos: 1. Hekate: 40. 161. 201; Chthonia 148; Leukothea 62. Helios: 63. 103. 143; Aneiketos 30; Apollo H. Lairbenos 5; Zeus H. 119. Hephaistos: 120. Hera: 1. 207; Basilissa 13. Herakles: 8. 11. 40. 44. 45. 67. 97. 102. 191; Lenktriades: 156. Hermes: 17. 34. 44. 67. 69. 97. 103. 190. 191; Agoraios 17; Chthonios 17. 148; Dolios 17; Dromios 17; Eriounios 17. 29; Propylaios 17. Heroine: 1. Horai: 205. Hygieia: 152. Kore: 34. 54. 109; Plyaris 39. Kybele: 135. 148. 161. Leto: 68. 143. Leukothea: 25. Mes: 104. 105; Askaienos 14. Messene: 192. Meter: 196; Kadmene 135; Oreia 58; Theon 12. 149; Tymenaia 136. Muses: 44. 82. 152. Nemesis: 26. 38. 39. 185. 188. Nymphs: 42. 111; Nymph Halia 90. 118. Pan: 202. Paralos: 1. Parthenos: 45. Pasikrata: 40. 62. Persephone: 29. Plouton: 39. 40. 54; Basileus 109. Poseidon: 42. 77. 133. 203; Kyanochaites 13. Praxidika: 152. Thea Rhome: 11. 128. 169. 176. Theoi: Dodeka 67; Megaloi 155; Pantes 3; Patroioi 137; Proimoi 41. 167. 175. Theos: Hypsistos 37. 39; Megas 32. Tyche: 29. Zeus: 6. 35. 40. 103. 106. 158. 177. 189; Agoraios 7; Aizanites 189; Eleutherios 82; Heliopolitanus 103; Helios 119 Hypsistos 40. 207; Karpodotes 161; Ktesios 154; Lykaios 108; Megistos 33. 35; Meilichios 72. 77. 81; Nautamenos 119; Nineudios 34. 39; Ombrimos 13; Ombrios 13; Orkamaneites 79; Ouranios 63; Patroios 39; Phratrios 88. 89; Solymeus 32; Soter 22. 57. 66. 115. 161; Spaloxios 39

deity, assimilation of: 63; chthonic: 77.134 ; patron of adolescence 71 ; of animal husbandry: 42; of civic institutions: 17; of growth 62. 143; of fertility: 17. 41. 42; of fishing: 33; of the gymnasion: 17; of healing water: 102; of an individual: 143 ; of the light 77 ; of navigation: 45.49 ; of village 100; rescuer: 149 ; superiority of one deity over others: 36 ; see also s.v. divine punishment, epiphany, epithet, justice

deity, Anatolian: Astron Kakasbeus 33; Meter Kadmene 135; Meter Tymenai 136; O(u)rda(s) 67; Egyptian: 20. 23. 37. 101. 152. 183; Oriental: Mithras 30. 183; Roman: Fulvus 183; Iupiter 103; 
Luna 14. 105; Mercurius 103; Sol Invictus 30; Sol 83; Venus 103; Syrian: Atargatis 103; Beelphegor

63; Dea Syria 103; Dousares 6; Hadad 103; Theandrites 6. Theandrios 6; Thracian: Bendis 201

deme, religious activities in: 1.19.197

Dionysiac artists: 38

disease: 55.56

distribution, during festival: 131

divination: 47.82 .84 .164

divine punishment: 26. 41. 93. 95. 125. 134. 143. 187; see also Greek words

dream: 87

dress: 153

dynamics, in rituals: 37

eagle: 39

ears, representation in relief: 39

emotion: 36; see also s.v. hope

endowment: 131. 143

Endymion: 145

ephebes: 44. 101. 126. 183. 201

epiphany: 22. 36. 45

epithet, acclamatory: 35.36

exorcism: 117

family, and cult: 143

fate: 26

federation, cult of: 106.108

festival: 36. 61; architecture: 172; commemorating a war victory: 78. 201; competition among cities: 35; Dionysiac artists in: 151; distribution of money: 131; order during f.: 53; rhapsodes in: 206; ticket for: 4; see also s.v. coin

festival, agonistic: in Boiotia: 9. 118; Agrionia 9. 118 (Thebes); 118 (Orchomenos); Alexandreios agon 78 (Thessalonike); Amarynthia 206 (Amarynthos); Amphiaraia 118. 171. 206 (Oropos); Asklepieia 206 (Epidauros); athlon Haliai Nymphai 118 (Oropos); Basileia 9. 29. 118 (Lebadeia); Brauronia 206 (Athens); Charitesia 118. 206 (Orchomenos); Didymeia 163 (Miletos); Dionysia 124 (Karthaia); Dionysia Herakleia 118 (Thebes); Eleutheria 9 (Plataia). 76 (Larisa); Epinikia 78 (Thessalonike); Erethimia 206 (Rhodes); Erotideia 9. 118 (Thespiai); Herakleia 9 (Thebes); Homoloia 118 (Orchomenos); Isthmia 148; Kabireia 78 (Thessalonike); Kaisareia Pythia 78 (Thessalonike); Mouseia 9. 118. 206 (Thespiai); Naia 206 (Dodona); Nemea 29. 148; Nemeseia 188 (Smyrna); Odysseia 28 (Ithaka); Olympia 27; Pamboiotia 9; Panathenaia 148. 159. 206; Ptoia 9. 35.118 (Akraiphia); Pythia 4. 78. 130 (Thessalonike). 147. 148 (Delphi); Rhomaia 118. 206 (Thebes); Sarapieia 118. 206 (Tanagra); Soteria 118. 206 (Akraiphia). 206 (Delphi); Trophonia 118 (Lebadeia) festival: Diombria 13 (Kallatis); Karneia 190 (Messene); Komaia 100 (Thasos); Pantheia 3; Tbiodaisia 139 (Lyttos); Velchania 139 (Lyttos)

finances of cult: 19.37. 54.126.138. 159. 186

fire rituals: 37

foundation legend: 6. 45. 60. 86. 145. 162. 169

funerary cult: 29.31 . 34. 77. 143; funerary foundation: 143 ; see also s.vv. burial, grave, rosalia

gem: 38. 46. 55. 56. 70

gladiator, gladiatorial event: 39.130 .188

grave, protection of: 32.33 .41 .125 .143 .176 .181 .187 
gymnasion: 29. 44. 97.111.126

hair offering: 14

hero: 60; hero of an individual: 143; heroes: Aitolos: 145; Amphiaraos: 171; Bellerephontes: 143; Endymion: 145; Narkissos: 96; Neleus: 60; Oxylos: 145; Phlogios: 60; Sarpedon: 143

heroic cult: 1. 113; Achilles: 45; Odysseus: 28

heroization: 143

heroon: 34

Homer: 143. 184

hope: 205

hymn: 37.205

identity: 37.45

imperial cult: 11. 26. 37. 61. 78. 83. 112. 114. 128. 140. 155. 158. 172. 176. 183. 187. 206

imprecation, funerary: 93. 181

incense burner: 39

incubation: 129

initiation: 1. 51. 190

innovation: 35

inventory: 111. 204

invocation of the emperor's fortune: 180

Jews: 117

justice: 29; divine: 26. 43. 95. 199

kerykeion: 20

kinship, mythical: 145

lamps, in cult: 37; in defixiones: 123

libation: 1. 52. 57. 115

magic: 37. 46. 70; handbook: 56; love m.: 55. 73; protective: 117; see also s.v. amulet, curse, defixio and Greek words

morality: 38.85

mystery cult: 24. 29. 31. 36. 51. 85. 153. 155. 190; see also Greek words

myth: 6. 11. 82. 86. 96. 145; mythical kinship: 86; see also s.v. foundation legend, hero

names, theophoric: 45

oath: 7. 131. 180; see also Greek words

oracle: 37. 87. 118. 132. 155. 164. 199. 205; moralizing: 38; see also s.v. alphabetical oracle

Orphics: 29. 31. 51. 65.85.196

paganism, survival of: 6; late p.: 170

Pausanias: 109. 145

philosophy: 6

piety: 29. 39. 54. 120.170; see also Greek words

politics and religion: 6.30.80.128

pollution: 129 ; see also s.vv. purification, purity

prayer: 29. 42; prayer for justice: 37. 93. 95. 199; see also Greek words 
priesthood; association of priests: 116. 177; for life: 41. 175; remunaration of: 1 ; and sacrifice:

141; see also s.v. cult personnel

procession: 45.92

propitiation, sacred: 36

prostitution: 88 ; see also s.v. pollution, purity

purification: 47

purity: 129; of the heart: 29; see also Greek words

Pythais: 92

rite of passage: 71.139

ritual: agency: 37; dynamics: 37 ; emulation of: 37 ; identity through r.: 35 ; internalization: 85 ; interruption because of war: 143; introduction of: 37 ; revival of: 35 ; transfer of: 37 ; see also s.vv. acclamation, agency, archaism, banquet, bath, birthday, burial, commemorative ritual, crowning, cry, cult, fire, funerary cult, hair offering, hymn, incubation, initiation, innovation, libation, magic, mystery cult, oath, prayer, procession, purification, Pythais, rite of passage, rosalia, sacrifice, supplication, theoria, vow, wedding; see also Greek words

river god: 45.133

rock-cut relief: 135

Roman Empire, impact on rituals: 37. 82. 83

rosalia: 37

ruler cult, Hellenistic: 74. 128. 185. 194. 198

sacrifice: 1. 35. 42. 82. 124. 126. 141-143. 154. 201. 205; approval of victim: 59; burning of the victim: 1; cake: 1. 201; chthonic: 144; facilities: 34; honors in s.: 124; marking of victim: 59; meat, consumption of: 142; Olympian: 144; share of priest: 1; share of benefactor: 143; see also s.v. animal/sacrificial and Greek words

sanctuary, administration: 110; bank: 108; building erected with sacred funds: 138; buildings: 68; conflict resolution in: 143. 192; facilities: 54; financial administration: 186; frontier s.: 58; location of: 40; political role: 108; property: 161; recipient of fine: 5. 32. 33. 143; and territorial claims: 58; see also s.v. finances

silence: 205

slave: 39; sacred: 88

soldiers, cult association of: 129

soul: 29. 38. 125. 127. 150

statue, decoration: 120; dedication of: 5. 102; dressing: 204; erection of: 154

suicide: 150

supplication: 7

table, offering: 54. 157; sacrificial: 105

tax, for erection of an altar: 54

theoria: 82

torch race: 101.114

trapezones: 54

vision: 87

vow: 13. 33. 39. 63. 67. 68. 79. 105. 134. 136. 189. 207

wedding: 139

wine: 1

woman: 39. 54. 88. 153.175. 197; and sacrifice: 141.143. 153 


\section{Greek words (a selection)}

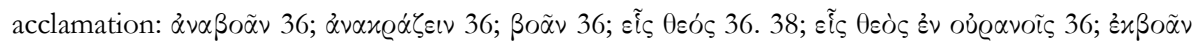

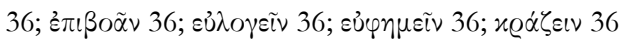

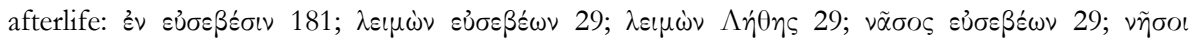

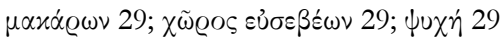

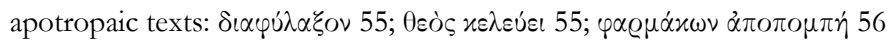

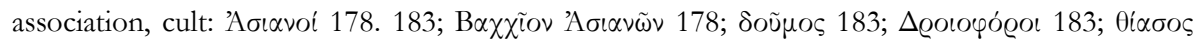

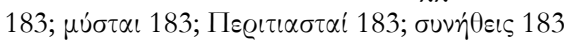

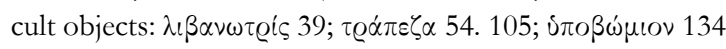

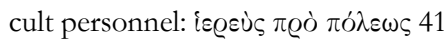

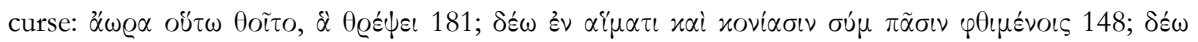

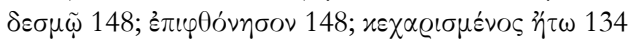

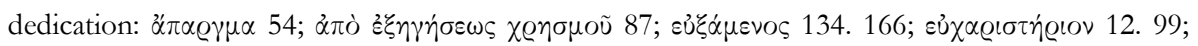

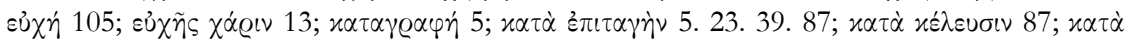

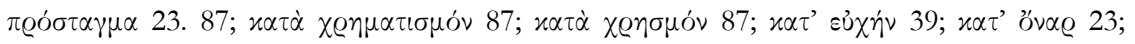

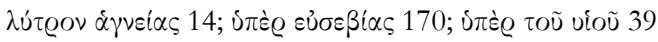

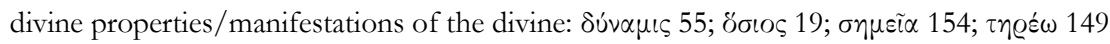

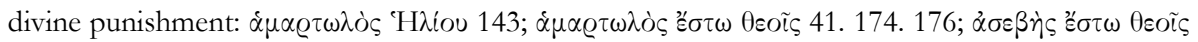

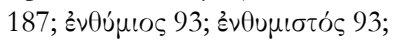

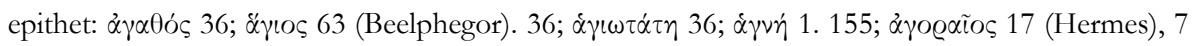

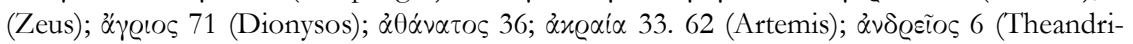

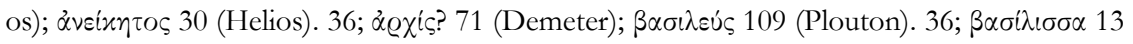

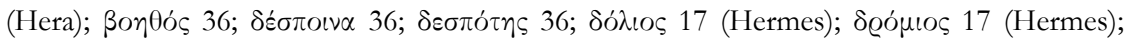

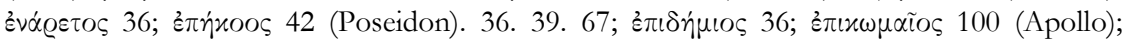

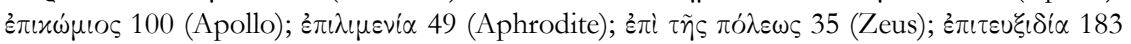

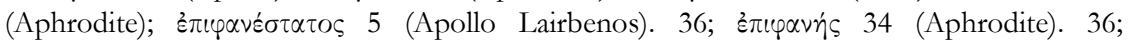

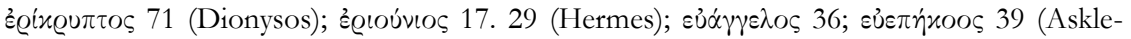

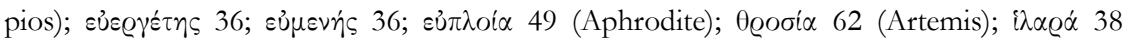

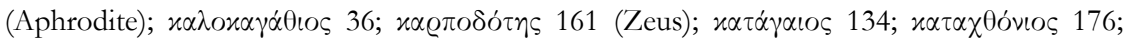

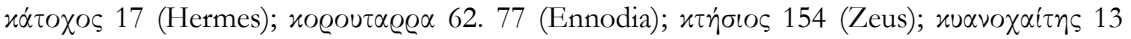

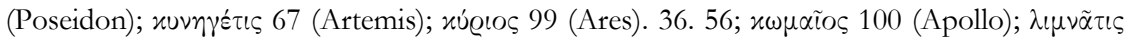

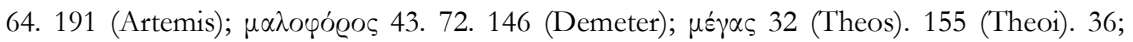

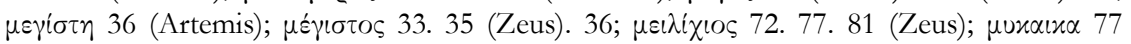

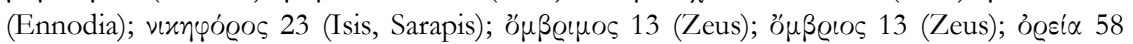

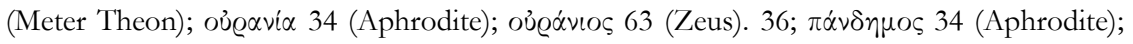

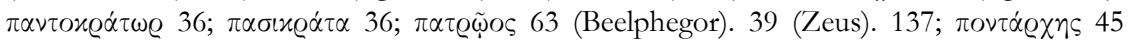

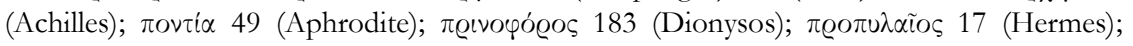

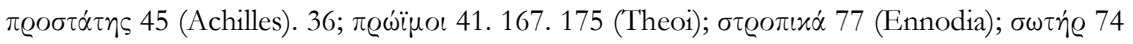

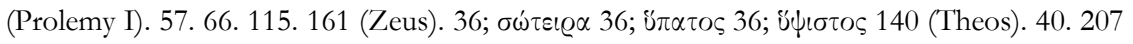

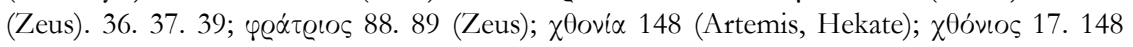

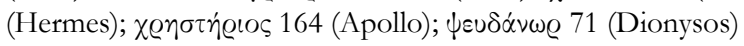

festival: ér

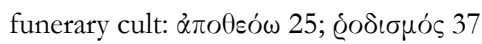

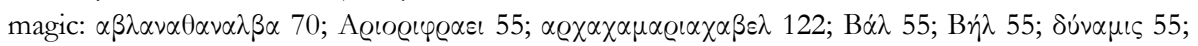

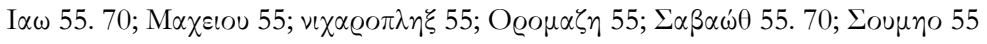

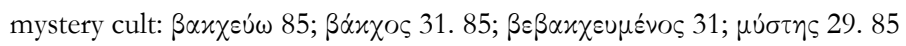




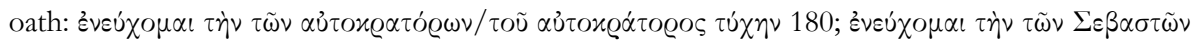

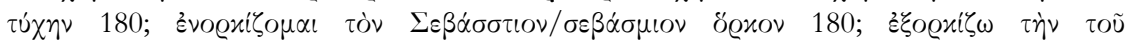

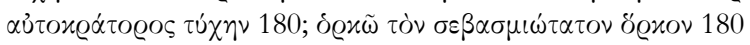

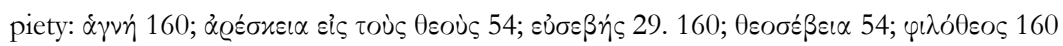

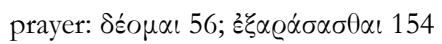

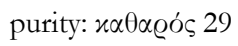

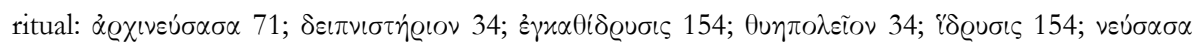

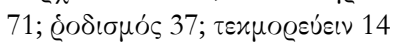

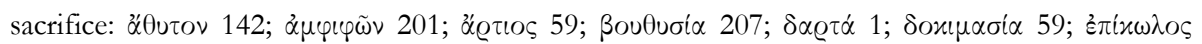

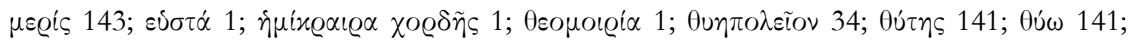

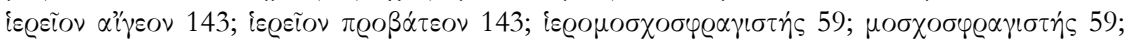

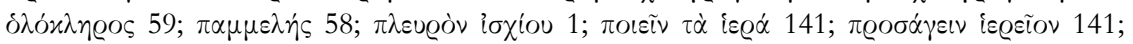

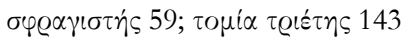

soul: $\psi \cup \times \dot{n} 38$

1) D. ACKermanN, "Rémunération des prêtres et déroulement des cultes dans un dème de l'Attique", LEC 75 (2007), p.111-136: A. provides a detailed commentary on the cult regulation of Aixone (ca. 400-375; SEG LIV 214; EBGR 2004, 256), which lists the

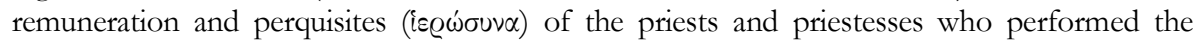
sacrifices in this Attic deme. The surviving fragment concerns sacrifices for an unknown divinity whose name is restored as Heroine, Dionysios Anthios, Hera, Demeter Chloe, an anonymous goddess (Eleusinia?, i.e. Demeter), Hagne Theos, Paralos, and Archegetes. The majority of the priests and priestesses received the skin of the victim, a share of the meat, as

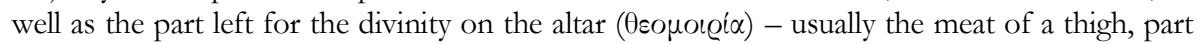

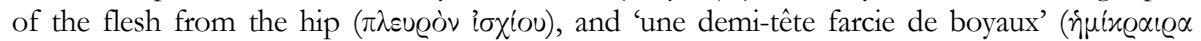
$\chi \varrho \varrho \delta \tilde{\eta} s)$. The priestess of Demeter did not receive the skin of the victim, certainly because the victim was a pig whose skin was burned on the altar. The priests of Dionysos did not receive a share of meat, possibly because this cult was less expensive. In the case of Hagne Theos, Paralos, and Archegetes the victim entirely burned on the altar, and this explains why the priests did not receive a share. All the priests received monetary remuneration of five drachmai, which should not be interpreted as a cultic tax (as assumed by G. Steinhauer) but as a 'basic salary' for all deme priests for their services during the main deme festivals. The priestesses of Heroine and Hera were paid an additional sum (three drachmai), possibly for an additional (preliminary?) sacrifice during which the skin of the victim was burned (cf. the distinction between the designation of victims as $\delta \alpha \varrho \tau \dot{\alpha}$ and $\varepsilon \dot{v i \alpha} \dot{\alpha}$ in LSCG Suppl. 19 lines 32f.). Finally, the priest and priestess of Hagne Theos and the priest of Paralos received additional sums of ten drachmai each, probably for the purchase of sacrificial animals (sheep). Additionally, the priests received food items (wheat, honey, oil, wine, barley) and material (timber, scrub), which permits a reconstruction of the sacrifice (deposition of sacrificial cakes, libations of wine and oil, purification through oủ $\alpha \hat{\imath})$. Two matters of detail: A. rightly points

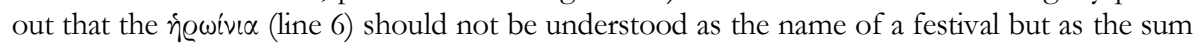
of sacrifices offered during the festival of Heroine (p. 115 note 12). As regards Hagne Theos, A. observes that since the sacrificial meat was not consumed, this goddess was somehow associated with death; death, in turn, was connected with initiation rites. For this reason she suspects that the Hagne Theos was Artemis (p. 116 note 19) [cf. infra no 2]. A. stresses the great diversity in the cults of this deme and the rather small scale of the sacrifices, due to limited resources. As regards the different treatment of gods and heroes, neither this nor other regulations allow generalizations. 
2) D. ACKermann, "L'Hagnè Theos du dème d'Aixôn en Attique : réflexions sur l'anonymat divin dans la religion grecque antique", $A R G 12$ (2010), p. 83-118 [BE 2011, 224]: The cult regulation of Aixone (ca. 400-375; SEG LIV 214) [supra no 1]. mentions a goddess designated as Hagne Theos. Based on Pausanias' reference to Hagna in Andania (Paus. IV, 33, 4), G. Steinhauer identified the goddess worshipped in Aixone as Kore. However, the Andania inscription (IG V.1.1390) shows that Hagna in Andania was the nymph of a local spring. Hagne is used as a cult epithet of several goddesses (Artemis, Thea Syria, Meter Theon) but never for Kore. A. studies the phenomenon of anonymous deities, referred to with an attribute and not

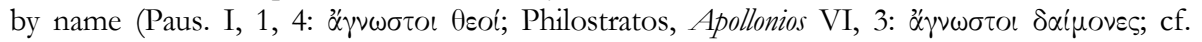

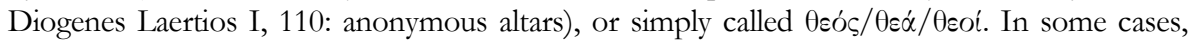
their identity was obvious because it could be inferred from the place of dedication; in other cases, the name was concealed due to 'euphemism' (e.g. Semnai Theai) or because of the requirements of mystery cults (e.g. Despoina, Megaloi Theoi). In the case of Aixone, some indications of the goddess' identity are given by the fact that the victims were burned on the altar, which implies a chthonic cult. That a priest and a priestess served her denotes a distinction between female and male worshippers probably in purification rites (cf. the telete in the Korybantic mysteries in Erythrai: LSAM 23). The anonymity of the Hagne Theos in Aixone may be connected with initiatory rites.

3) M. ADAK, "Die rhodische Herrschaft in Lykien und die rechtliche Stellung der Städte Xanthos, Phaselis und Melanippion”, Historia 56 (2007), p. 251-279: Ed. pr. of an honorific decree of Melanippion (Lykia) for Apollonios of Phaselis (ca. 186 BCE). Apollonios was to be crowned every year during his lifetime [on 1. 18, read $\sigma \tau \varepsilon \varphi \alpha \nu[o \tilde{\nu} v]$ not $\sigma \tau \varepsilon \varphi \alpha \nu[\tilde{\omega} \sigma \alpha l]]$ at the festival of the Pantheia (cf. the month names Pantheios and Pantheon) [a festival for Pantes Theoi]. The inscription was set up in the sanctuary of Athena, the city's main sanctuary (cf. Quintus Smyrnaeus, 233).

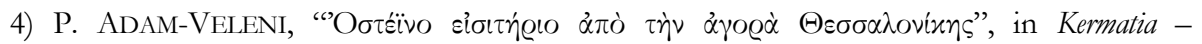
Touratsoglou II, p. 601-605 [SEG LIX 711]: Ed. pr. of a round bone plaque found in the Roman forum (mid-3rd cent. CE). An incised palm wreath and the inscription $\prod^{\prime} \theta \imath \alpha$ appear on the obverse, which shows that this object was used as a token for spectators attending the Pythia. The numerals on the reverse (III $\mid \Gamma$ ) probably refer to a spectator's seat assignment [or possibly to a civic subdivision; we may not have two numerals but the number three in Latin and Greek]. A.-V. attributes this ticket to the period of the festival's re-organization (ca. 240252) [on the Pythia see EBGR 2006 and infra no 78. The Pythia seem to have continued after $252 \mathrm{CE}$, possibly until the early 4th cent. CE].

5) E. AKINCI ÖZTÜRK - C. TANRIVER, "New Inscriptions from the Sanctuary of Apollon Lairbenos", EA 43 (2010), p. 43-49 [BE 2012, 29 and 403]: Ed. pr. of seven inscriptions from

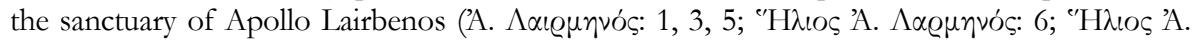

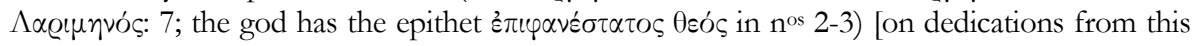
sanctuary cf. EBGR 2008, 1 and 2009, 4]. Two brothers from Blaunda dedicated 'a column together with the platform, the base, the capital, the architrave, the freeze, and the cornice', i.e. they covered the expense for an intercolumnium in the sanctuary $(1,2$ nd cent. CE). A fragmentary text records the dedication of other architectural elements, including roof tiles $(2$, 1st/2nd cent.). A man and his daughter dedicated a statue upon divine command ( $x \alpha \tau^{\prime}$

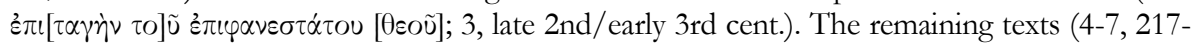
219 CE) are dedications of persons (katagraphai). The dedicated persons were alumni (4-7) and possibly a family member (4); the dedicants came from Motella (5-7). The consecration is

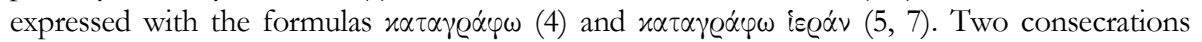

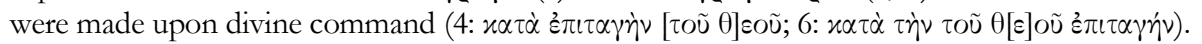


In one case the dedicant had the consent of family members (parents and son: 5; son: 6 ). Violations of these acts of dedication were punishable by fines paid to the sanctuary and the fiscus (4-7).

6) J. Aliquot, "Dans les pas de Damascius et des néoplatoniciens au Proche-Orient : cultes et légendes de la Damascène", REA 112 (2010), p. 363-374: The fragments of Damascius' Life of Isidoros, which describe the journey of the Neoplatonic philosopher Isidoros in South Syria and the Damaskene (489/90 CE), can be placed in the context of the survival of pagan cults and myths in this area. A. discusses in particular the cult of Theandrios or Theandrites in Hauran and its vicinity. In Damaskos, Theandrios was associated with Zeus. In an intaglio of unknown provenance he was invoked together with Ares and Dousares. He was also worshipped by Syrian immigrants in the Western provinces. An inscription from Rimé (east side of Mt. Hermon; IGLS XI, 41; cf. EBGR 2008, 5), which records the erection of a temple for $\theta \varepsilon o$ s ¿ $2 \delta \varrho \varepsilon i o s$, is a further attestation of this cult. In Damaskios' work, Theandrios (the virile god) was subject to a Platonic interpretation. His properties associated him with Shay al-Qawm and Lykourgos. The latter was connected with foundation legends of Damaskos. This was the place where Dionysos defeated the Arab Lykourgos ( $\left.\delta \alpha \mu \alpha \zeta_{\omega} \omega \Delta \alpha \mu \alpha \sigma x o ́ \varsigma\right)$. This legend was later exploited by the Seleucid Antiochos XII Dionysos in his struggle against the Nabatean king - a new Lykourgos. In addition, the dedication of a bronze statue of a bull to Orion (valley of Barada, SEG XL 1397), albeit unrelated to cults of the Roman army, should be interpreted with reference to the perception of the Damaskene as a 'wild' region, analogous to Arcadia; according to mythology, Artemis defeated the giant Orion.

7) C. AntonetTI, "Riflessioni su Zeus Agoraios a Selinunte", in Temi selinuntini, p. 29-51: With the cult of Zeus Agoraios in Selinous as her starting point, A. collects archaeological, epigraphic, and literary sources for the political functions of Zeus Agoraios and the values associated with this god in the Archaic and Classical periods. Agoraios was associated with oaths and the safeguarding of institutions, the protection of suppliants, and banquet rituals of kinship groups (e.g. in Thera).

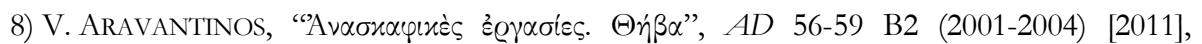
p. 124-159 [partly presented in EBGR 2009; BE 2012, 200]: To the report in EBGR 2009, 11, we add that in the area of the sanctuary of Herakles, a bronze tablet was found with the text of

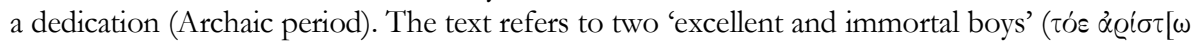
...] $\tau o ́ \varepsilon \dot{\alpha} \theta \alpha \nu \alpha \dot{\alpha}[\tau \omega$...] $\pi \alpha \tilde{\imath} \delta \varepsilon)$ [the sons of Herakles?]. A bronze kantharos dedicated to Apollo Hismenios was discovered in the area of an altar east of the sanctuary of Herakles (p. 134) [an oracle of Apollo Hismenios existed southeast of the Electran Gates].

9) G. ARgoud, "Principaux concours en Béotie dans l'antiquité", in Synedrio Boiotikon Meleton

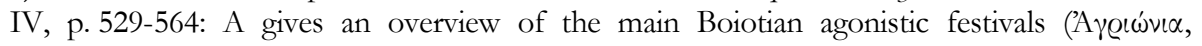

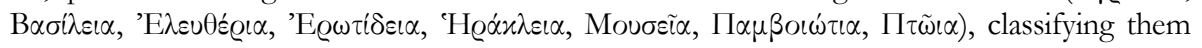
into three categories: military/commemorative, panhellenic, and civic. [For a criticism of this classification see D. KNOEPFLER, BE 2010, no. 270.]

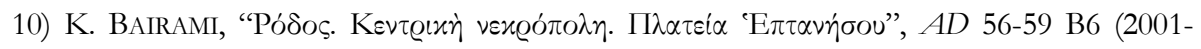
2004) [2012], p. 265-266: B. mentions the discovery of four graves in the central cemetery of Rhodes, in which an unspecified number of lead tablets with defixiones were found. The discovery of defixiones in another cemetery is also reported by C. FANTAOUTSAKI, "Oঠò

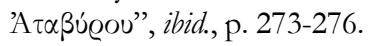

11) D. BALDASSARRA, "Il contributo dell'epigrafia allo studio delle famiglie notabili Messenie (I-III sec. d.C.). Il caso dei Flavii Kleopha(n)toi e dei Flavii Polybioi. I”, Epigraphica 70 (2008), p. 119-141 [SEG LVIII 366]: B. reconstructs the stemmata of two aristocratic families in 
Messene in the Imperial period and discusses their public service, which included holding priestly offices. She also republishes eight relevant inscriptions. They concern Kleophantos, the first priest of Nero and priest of Roma ( $1=I G$ V.1.1449), and T. Fl. Polybios, priest of Roma $(6=I \nu O$ 486; mid-3rd cent. CE). B. presents the unpublished funerary inscription for this

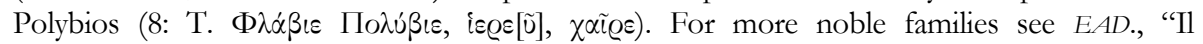
contributo dell'epigrafia allo studio delle famiglie notabili Messenie (I-III sec. d.C.). II. La famiglia di Aelius Aristo di Messene e gli Iulii Theaghenai di Corone", Epigraphica 71 (2009), p. 203-221. One of these elites was Harmomikos, a descendant of Herakles and the Diskouroi, whose portrait was dedicated in the sanctuary of Ithome (IG V.1.1399).

12) M. BĂRBUleSCU - A. CÂTEIA - W. WisOŞENSCHI, "Piese epigrafice şi sculpurale din teritoriul rural", Pontica 42 (2009), p. 409-427 [SEG LIX 788]: Ed. pr. of a thanksgiving

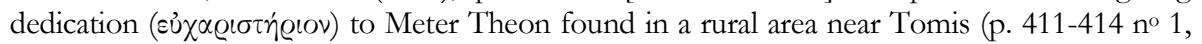
3rd cent. CE).

13) A. BARneA, “Les Grecs de la ville romaine de Tropaeum Traiani”, in G. VotTÉRo (ed.), Le grec du monde colonial antique. I. Le N. et N.-O. de la Mer Noire. Actes de la Table Ronde de Nancy, 28-29 septembre 2007, Nancy, 2009, p. 119-122 [SEG LIX 794-796]: Ed. pr. of an inscription on an altar that commemorates the dedication of a sanctuary to Zeus Ombrimos on behalf of Emperor Maximinus Thrax and his son (Tropaeum Traiani, ca. 236-238). This inscription is of great interest because Zeus Ombrimos is exclusively attested in the Imperial period in Moesia

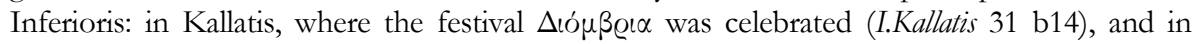
Histria (I.Histriae 334). Zeus Ombrios (cf. Ombrimos) is documented mainly in literary sources. The new text joins two other dedications made to gods with uncommon epithets at this site in the early 3rd cent. CE: dedications addressed to Hera Basilissa and Poseidon Kyanochaites in fulfilment of vows ( $\varepsilon \dot{\chi} \chi \tilde{\eta} \varsigma \chi \alpha \dot{\alpha} \varrho \nu)$ following the discovery of water sources

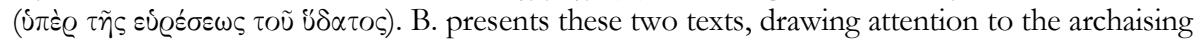
features of the epithets (cf. the form Побєเ $\delta \dot{\alpha} \omega v)$, which may be attributed to education and literary interests.

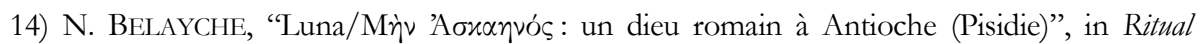
Dynamics, p. 327-348: B. studies the origins of the cult of the lunar god Mes Askaenos ( $\theta$ sòs

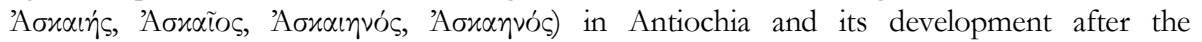
establishment of a Roman colony [see also infra nos 104-105]. In the Hellenistic period, oikoi composed of a court and two rooms offered space for ritual banquets organized by cult associations, a practice that continued into the Imperial period. The offering of the hair of five threptoi as $\lambda$ úteov áyveías ('prix de leur pureté'), mentioned in an epigram of the Imperial period (CMRDM IV no. 127), probably concerns a ritual inherited from the pre-Roman period. In the Imperial period, the local god was identified with Luna and integrated into the pantheon of the Roman colony. The extra-urban sanctuary on the Karakuyu Hill, then connected with the city by means of a processional road, attracted Roman colonists who continued the Greek ritual

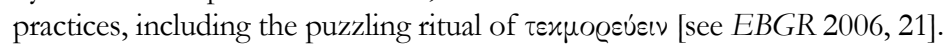

15) L. BetTARINI, "Defixio selinuntina inedita da Manuzza", PP 64 (2009), p. 137-146: Ed. pr. of a defixio from the hill of Manuzza in Selinous (5th cent.). The text is very fragmentary. One recognizes a few names and the word $\gamma \lambda \tilde{\omega} \sigma \sigma \alpha$; the defigens binds the tongue of his opponents.

16) G. BevilacQua, “... (h)os (h)omines ...: una nuova tabella defixionis da Olbia”, in M. MiLANESE et al. (eds.), L'Africa Romana. I luoghi e le forme dei mestieri e della produzione nelle province africane. Atti del XVIII convegno di studio, Olbia, 11-14 dicembre 2008, Sassari, 2010, III, p. 1935-1962: Ed. pr. of a curse tablet, partially preserved in eight fragments, found at Giuncalzu, near Olbia (Sardinia, 5th cent. CE). Only fragments of words can be detected (e.g. 
forms of depangere and defamare; perhaps dedo ... (h)os (b)omines). It seems that the victim is cursed to suffer from sleep deprivation ([ni possit] dormire). One also recognizes a reference to demones and the unusual expressions iura ligo and ligo aqua $(m)$.

17) G. BevilacQua, "Dediche ad Hermes", in Dediche sacre, p. 227-244: Stressing the heterogeneity of dedications to Hermes, due to the god's different aspects, B. focuses on dedications that highlight his function as a patron of civic space and civic institutions (Hermes Propylaios, Agoraios, Dromios; patron of the gymnasion; patron of fertility and trade; patron of social order and the magistrates). She also discusses in detail an altar dedicated to Hermes Dolios in Kyrene (SECir 154, late 6th cent., p. 240-244). For this text she proposes the following

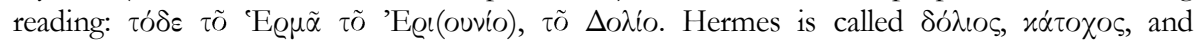
E̊ıóvios in Attic defixiones. If the altar was used for a single cult, the two epithets alluded to two opposing properties of the god: benevolent, cunning, and deceptive. If we are dealing with a single cult, the epithets denote the properties of Hermes Chthonios.

18) J. BLÄNSDORF - A. KROPP - M. SCHOLZ, "Perverse agas, comodo hoc perverse scriptum(m) est'. Ein Fluchtäfelchen aus Köln”, ZPE 174 (2010), p. 272-276: Ed. pr. of a Latin curse tablet from Cologne (1st cent. CE). The text is written sinistrorsum and expresses the wish that exactly as the letters are reversed, the victim's life should also go the wrong way: $V$ aeraca, sic res tua: perverse agas, quomodo hoc perverse scriptum est. Quidquid exoptas nobis, in caput tuum eveniat [('Veraca, this should happen to you. Exactly as this is written in the wrong way, let you too live in the wrong way. Whatever you wish against us, may it fall upon your head')].

19) J.H. BLOK, "Deme Accounts and the Meaning of hosios Money in Fifth-Century Athens", Mnemosyne 63 (2010), p. 61-93: After detailed study of accounts from Athenian demes (Ikarion:

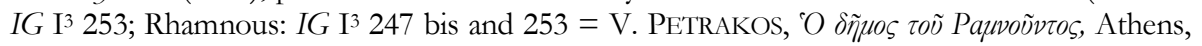
1999, II, nos 181-182; Ploteia: IG I ${ }^{3} 258$, 5th cent.), B. convincingly rejects the traditional interpretation of money designated as öбıv. The money was not free for secular use, but rather intended for public use in a manner pleasing to the gods.

20) M. Bonanno Aravantinos, "Stele funerarie di età Romana da Tanagra con raffigurazione di personaggi legati alla sfera religiosa", in Ergo Thessalias - Stereas 2, p. 1151-1165: Study of the iconography and inscriptions of six funerary reliefs with representations of individuals with religious functions (Tanagra, ca. 1st cent. BCE-2nd cent. CE). The stelai belong to two women in the service of Isis (IG VII 1621 and 1636); two women with attributes of Maenads (IG VII 1581, 1603/1604); a man with a kerykeion (IG VII 1518); and a woman with a kerykeion (uninscribed).

21) D. Bosnakis - A. Dreliosi-Iraklidou - T. Marketou, "Káduuvoc", AD 56-59 B6 (2001-2004) [2012], p. 314-315: A Late Archaic dressed kouros with a dedicatory inscription (late 6th cent.) was found in the sanctuary of Apollo at Pigadia (Kalymnos, p. 315).

22) T. Boulay, "Une épiphanie de Zeus Sôter à Clazomènes", RN (2009), p. 113-127: Tetradrachms issued by Klazomenai in the mid-2nd cent. feature Zeus Soter Epiphanes on the obverse and an Amazon on the reverse. B. argues that these coins were minted for use during a festival celebrating an epiphany of Zeus Soter that saved the city, possibly during the war between Prousias II and Attalos II (155 BCE). B. collects evidence for the cult of Zeus Soter and for epiphanies to which Hellenistic cities attributed their rescue from an enemy attack (118-121).

23) M.-F. Boussac, “À propos des divinités de Taposiris Magna à l'époque hellénistique”, in Paysage et religion, p. 69-74: Ed. pr. of a dedication to Sarapis and Isis Nikephoroi (Taposiris, Hellenistic). The dedication was made upon divine command ( $\left.\varkappa \alpha \tau^{\prime}[\varepsilon ̇ \pi \tau \alpha \gamma \dot{\eta} \nu / \pi \varrho o ́ \sigma \tau \alpha \gamma \mu \alpha]\right)$ [or

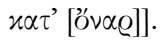


24) H. BowDen, "Cults of Demeter Eleusinia and the Transmission of Religious Ideas", in Greek and Roman Networks, p. 70-82: B. provides a list of 27 known sanctuaries of Demeter Eleusinia, especially in Ionia and the Peloponnese. In some cases (Megalopolis, Onkeion, Pheneos, Keleai, Lerna, Amdania, Ephesos, Pergamon, Alexandria) the performance of mysteries is attested. There is no direct evidence for on-going, formal relations between Eleusis and these sanctuaries. B. discusses the possibility of 'religious experts' on the diffusion of the cult and the transmission and interpretation of ideas connected with it.

25) G.W. Bowersock, Review of J. AliQuot, Inscriptions Grecques et Latines de la Syrie. Vol. 11, Mont Hermon (Liban et Syrie), Beirut, 2008, Topoi 16 (2009), p. 609-616: In a review of Aliquot's corpus (see EBGR 2008, 5), B. discusses in some detail the dedication for Leukothea from 'Ayn al-Burj (ancient Segeira; no $39=$ OGIS 611; IGR III 1075) made by a relative (father or

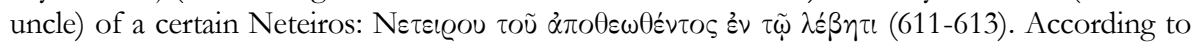
Aliquot, this phrase simply means that Neteiros' ashes were deposited in a cauldron, used as an urn. B. finds this interpretation unconvincing, since cremation was not practiced in this area, and $\alpha \pi \circ \theta \varepsilon \dot{c}_{\omega} \omega$ can be used as a metonym for death (e.g. in $M A M A$ VIII 570) but not for burial. Accidental death by falling into a cauldron of boiling water (as suggested by M. SARTRE, Syria 70,1993 , p. 64) is the most likely interpretation, as corroborated by a Christian parallel (Life of Theodore of Sykeon 112).

26) H. BRU, "Némésis et le culte impérial dans les provinces syriennes", Syria 85 (2008), p. 293-

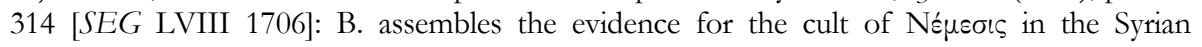
provinces (esp. 2nd/3rd cent.). The main properties of the goddess are those known from other areas as well: punishment, fate, victory, and justice. Nemesis was closely associated with contests in the context of the imperial cult.

27) S. BRUNET, "Winning the Olympics without Taking a Fall, Getting Caught in a Waistlock, or Sitting Out a Round", ZPE 172 (2010), p. 115-124: B. collects the evidence for wrestlers who won extraordinary victories in the Olympic games and other agonistic festivals. Their

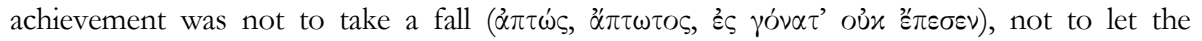
opponent grab them around the waist ( $\alpha \mu \varepsilon \sigma o \lambda \dot{\alpha} \beta \eta \tau o \varsigma)$, and not to sit out any of the rounds that a match might involve (ảvé

28) H.-G. BuchHoltz, "Some Remarks Concerning the Heroon of Odysseus at Ithaca", in

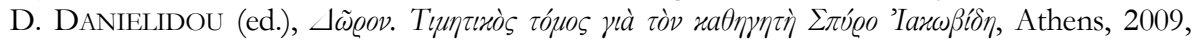
p. 127-142 [BE 2009, 21]: The decree of Ithaka accepting the asylia of Magnesia on the Maeander (IG IX 2.1 .1729 = RIGSBY, Asylia no. 86) mentions the sanctuaries of Odysseus

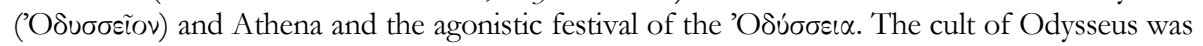
served by a priest. B. argues that the Odysseia could not have taken place at the cult place of

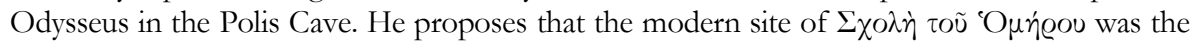
location of the sanctuary of Odysseus and summarizes the archaeological finds from this area.

29) É. CAIron, Les épitaphes métriques hellénistiques du Peloponnèse à la Thessalie, BudapestDebrecen, 2009 [BE 2010, 361, 371-374, 376, 380, 384-388, 390]: C. presents a corpus of 101 Hellenistic funerary epigrams from southern and central Greece. She briefly discusses some of the information provided by the texts with regard to funerary practices and ideas about the afterlife (15f.). Cremation is mentioned in two cases $(21=G V$ 1361, Athens; $69=G V 1748$, Demetrias); a text describes the grave of a three-year old girl as decorated with seasonal flowers $(99=G V 840$, Demetrias). There are several references to Hades $(6,39,41,49,66,68)$ and Tyche $(16,85)$. [We examine in more detail the significance of some of these epigrams for ideas about the afterlife. The most interesting text is the epigram for Agathokles of Corinth (70 $=G V$ 1572, Demetrias), which takes the form of a prayer to Persephone that she receive 
Agathokles in the area reserved for the pious, in view of his honesty, justice, and pure heart: 'Persephone, who arouses dread, receive a devout man, Agathokles, who descends to you, a leader in kindness; settle him in the meadow of the pious; for while he was alive he was

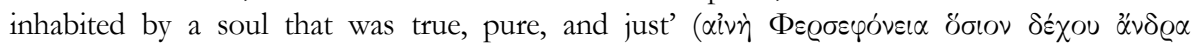

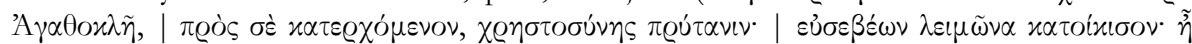

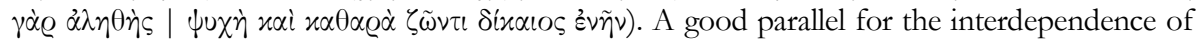
piety, purity, and justice is the metrical cult regulation from Euromos (SEG LXIII 710: Ei

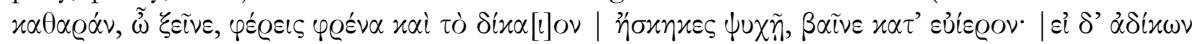

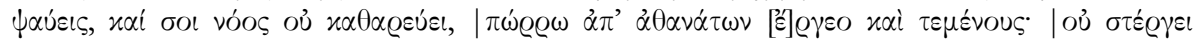

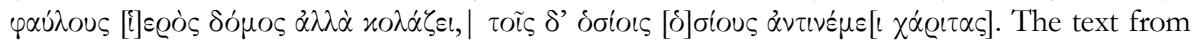
Demetrias reflects the idea that in order to join the Blessed in the underworld one needs to do more than perform certain rituals (initiation, purification); one also needs to be pure of heart and just. For this idea see A. CHANIOTIS, "Greek Ritual Purity: from Automatisms to Moral Distinctions”, in P. RÖSCH - U. SIMON (eds.), How Purity is Made, Wiesbaden, 2012, p. 123-139 (with further bibliography). An association with Dionysiac-Orphic ideas, as suggested by Cairon (p. 225), is possible. Two related texts express the hope that a deceased woman will be

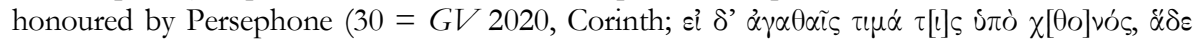

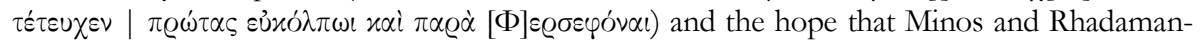
thys will judge a woman worthy of the islands of the Blessed $(86=G V 1693$, Demetrias: 'Rhadamanthys, if you have judged another woman to be kind, or you, Minos, also lead this woman to the Island of the Blessed, the daughter of Aristomachos. For she practiced piety and

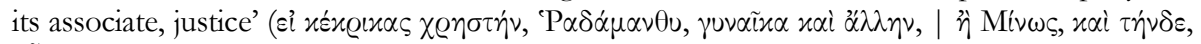

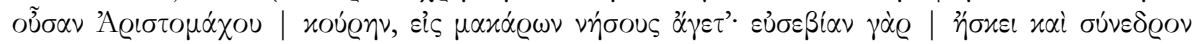
$\tau \tilde{\eta} \sigma \delta \varepsilon \delta(x \alpha \iota \sigma u ́ v \eta \nu)$. For the association of piety with one's post-mortem fate see also no $95=$

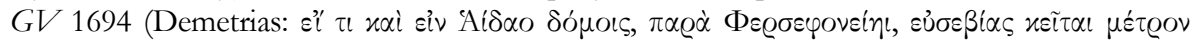

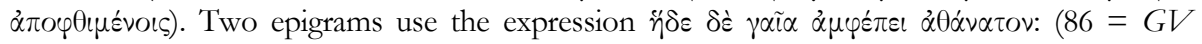

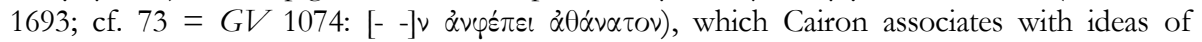
immortality and possibly with Orphism (p. 263-264). In an epigram from Larisa Hermes Eriounios is presented as conducting a deceased couple to the island of the pious ( $94=$ SEG

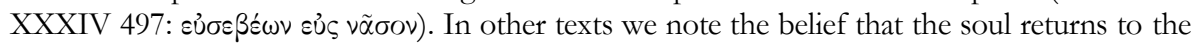
aither $(20=G V$ 527, Athens; $93=G V$ 1624, Larisa), or that the deceased has reached the area

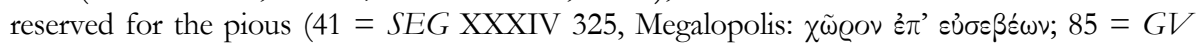

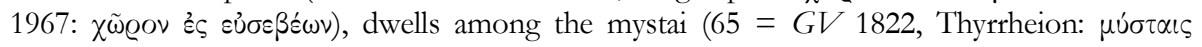
$\left.\alpha^{\prime} \mu \mu \tau \gamma \alpha \nu \alpha \varepsilon \tau \dot{\alpha} \omega\right)$, is sent by Minos to the islands of the Blessed (74 = GV 943, Demetrias), or lives among the heavenly stars $(77=$ SEG XXVIII 528). The latter text also expresses the idea that the deceased man originated from immortal fire (see the discussion in EBGR 2003, 6). Allusions to the 'geography' of the underworld are provided through references to the 'meadow of Oblivion and the chamber of Persephone' ( $42=G V$ 1505, Alipheira: $\Lambda \dot{\eta} \theta \eta \mathrm{n}$

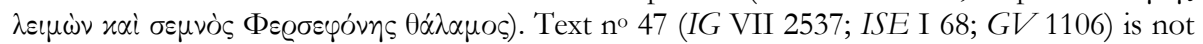
an epitaph but a posthumous honorary inscription, obviously inscribed on the base of the

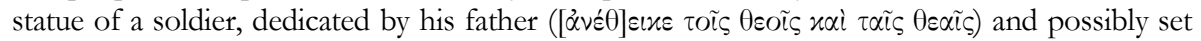
up in the gymnasion, which is mentioned in the epigram [for dedications in gymnasia see infra $\mathrm{n}^{\circ \mathrm{s}} 44$ and 97]. In an epigram from Demetrias (89 = SEG XXVIII 511) the deceased woman is presented as speaking from the grave, stating that she died after making a prayer to Demeter

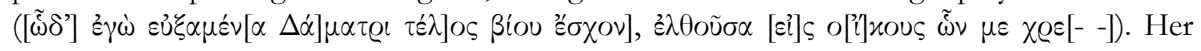
prayer must have referred to her afterlife. One of the epigrams was for an athlete who won victories at the Nemea and the Basileia (48 = GV 1004, Thebes), while another was for a flutist, 'who often in cyclic dances during contests gave pleasure to Lord Euios (Dionysos)

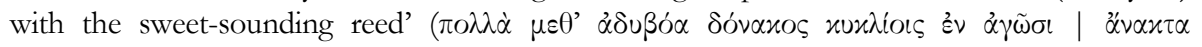




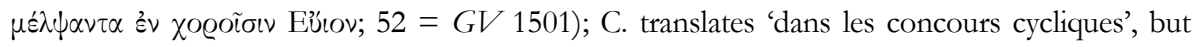

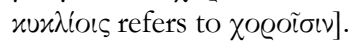

30) J.R. Carbó García, "La problématique de Sol Invictus. Le cas de la Dacie romaine", Numen 57 (2010), p. 583-618: C. collects the evidence for the cult of Sol Invictus/ ${ }^{\circ} \mathrm{H} \lambda \iota \mathrm{s}$ Aveixntos in Dacia. He underlines the heterogeneity of the evidence and the problems of interpreting whether dedications were made to the Roman or to the Syrian Sol Invictus, of associating them with Mithraic worship or the cult of other divinities (Hercules), or of attributing them to the popularity of Elagabal [cf. infra no 83]. Despite these problems, the evidence shows the increasing popularity of the worship of solar deities from the late 2 nd cent. CE on. There are only two Greek texts: a Greek dedication (I.Apulum 355) and a Greek/Latin bilingual dedication (I.Apulum 352; p. 611f. nos 5/6).

31) G. CASAdio, "Dionysus in Campania: Cumae", in Mystic Cults in Magna Graecia, p. 33-45: In a study of Dionysiac cults in Campania C. adduces the inscription from Kyme/Cumae that

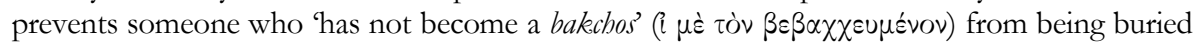
in a particular part of the cemetery, i.e., the communal burial ground of a community (koinon or thiasos) of bakechoi (SEG IV 92; 5th cent.). C. stresses the fact that our evidence does not permit a clear distinction between Dionysiac and Orphic ritual.

32) A.V. ÇELgIN, "Artemis Cults in the Territory of Termessos I", Adalya 6 (2003), p. 119-140 [SEG LIII 1609-1610, 1617-1619]: Ed. pr. of inscriptions concerning the cult of Artemis in Termessos and its territory. Two honorary inscriptions were set up for the wife of a priest of Megas Theos and a priest of Megas Theos (Imperial period, p. 131 note 73). [This Great God is erroneously identified by C.. as Artemis; T. CORSTEN, in SEG LIII 1609, rightly points out

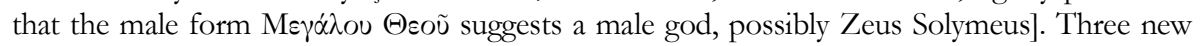
epitaphs (SEG LIII 1617-1619) mention fines payable to Artemis Kelbessis for any violation of the grave. The same epithet should be restored in TAM III 904 (not Thea Bessis).

33) A.V. ÇELgIN, “Artemis Cults in the Territory of Termessos II", Adalya 6 (2003), p. 141 170 [SEG LIII 1571, 1611, 1614, 1620-1625]: Ed. pr. of inscriptions concerning various cults in Termessos and its territory (p. 145f.; Imperial period). They include a dedication to Aspalos Artemis and Astron Kakasbeus. Adducing the cult of Artemis Aspalis in Thessaly, C.. interprets $\ddot{\alpha} \sigma \pi \alpha \lambda \circ \varsigma$ ( $(\chi \theta \dot{\varphi} \varsigma)$ as an indication that Artemis was worshipped as the patron of freshwater fishing. [On the cult of Artemis Aspalis see now EBGR 2009, 29; F. CANTARELLI, "Il mito di Aspális e il santuario di Haghios Gheorghios di Melitea", in F. CANTARELli et al., Acaia Ftiotide I. Indagini geostoriche, storiografiche, topografiche e archeologiche, Soveria Mannelli, 2008, p. 371-434, has

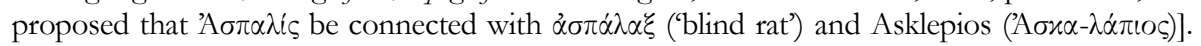
These dedications were made in fulfilment of vows. Another inscription honours a priest of Dionysos (Imperial period, p. 154). C.. also publishes six epitaphs from Neapolis (territory of Termessos) that threaten violators of graves with fines payable to Thea Artemis Akraia (in one

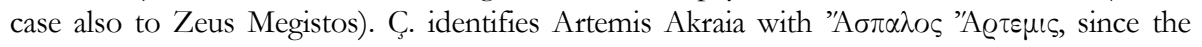
only attested temple, near the summit of the city's hill, is hers.

34) A. CHAniotis, "Twelve Buildings in Search of a Location. Known and Unknown Buildings in Inscriptions of Aphrodisias", in C. RATTÉ - R.R.R. SMITH (eds.), Aphrodisias Papers 4. New Research on the City and its Monuments (JRA Suppl. 70), Portsmouth, 2008, p. 61-78 [SEG LVIII 1181]: Discussion of the epigraphic evidence concerning buildings in Aphrodisias that have not been securely identified. Some of these buildings are of a cultic nature. 1) A sacrificial

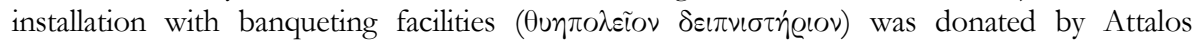
Adrastos in the early 2nd cent. CE (MAMA VIII 413) and placed under the supervision of

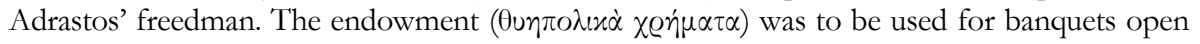


to the entire citizenry in honour of 'the manifest, heavenly goddess Aphrodite, the one who

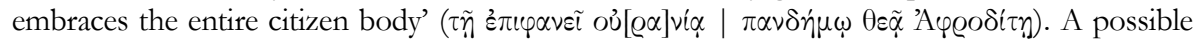
location is the unexcavated area of the precinct east of the temple, between the temple and the tetrapylon. 2) A sanctuary of Zeus Nineudios is attested in a Hellenistic building inscription on

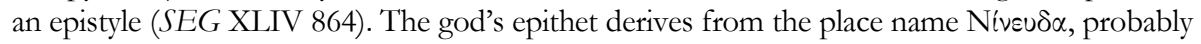
the earlier name of Aphrodisias (or one of the settlements which were incorporated into Aphrodisias) [for more details see A. CHANIOTIS, "New Evidence from Aphrodisias Concerning the Rhodian Occupation of Karia and the Early History of Aphrodisias", in R. van Bremen - M. CARBon (eds.), Hellenistic Karia, Bordeaux, 2010, p. 455-466]. The significance of the cult may be inferred from other epigraphic testimonia ( $M A M A$ VIII 410; SEG LIV 1037). The location of the sanctuary and the god's temple is unknown [for more evidence on this cult see infra no 39]. 3) The sacred precinct of Kore, presumably extra muros,

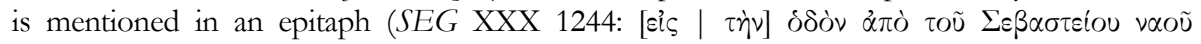

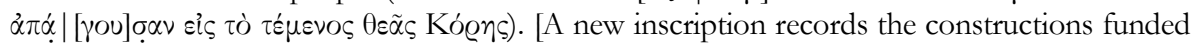
by a priest of Plouton and Kore; see infra no 39]. 4) A grove of palm trees was decorated with statues of Hermes, Aphrodite, and Erotes (1st/2nd cent. CE; $M A M A$ VIII 448). [This palm grove, also mentioned in a Late Antique inscription ( $A L A 38=I . A p h r .4 .202 \mathrm{i}$ ), has now been identified by Andrew Wilson north of the pool of the South Agora]. 5) The heroon of Adrastos and his granddaughter Tatia Attalis, local benefactors, was located in the city (late 1st cent. CE; SEG XLV 1502 and XLVI 1393). The heroon was to be constructed in the area of public sculptors' workshops near the bouleuterion, but Adrastos offered to have it built in his own workshops, which were not necessarily in the same location.

35) A. Chaniotis, "Konkurrenz und Profilierung von Kultgemeinden im Fest", in Festrituale, p. 67-87: The honorary decree for Epameinondas of Akraiphia (mid-1st cent. CE; IG VII 2712) is the starting point of this study of how festivals and celebrations expressed and promoted competition between communities. Epameinondas' innovations and benefactions were connected with the festival of the gymnasion, for which he funded new prizes ( $\dot{\alpha} \sigma \pi i \delta \varepsilon i \alpha$; cf. SEG XXX 1073; I.Sestos 1, 1. 79-83) and a luxurious banquet that was well regarded by neighbouring cities [see also infra nos 118 and 182]. Epameinondas restored the festival of the Ptoia, paying particular attention to local traditions and peculiarities, such as a traditional dance

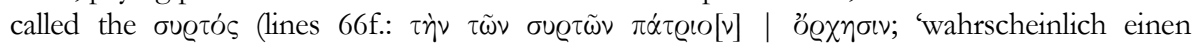
Reigentanz') [for a different interpretation see F. GRAF, in A. CHANIOTIS (ed.), Ritual Dynamics in the Ancient Mediterranean. Agency, Emotion, Gender, Representation, Stuttgart, 2011, p. 107-110: 'those in long trailing robes', or a 'trailing' or 'drawn out' dance of people holding each other's

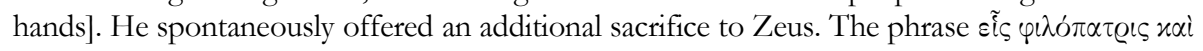

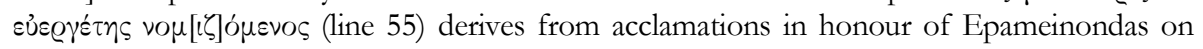
this occasion. As regards the sacrifice to Zeus Megistos mentioned in lines 85f., the text should

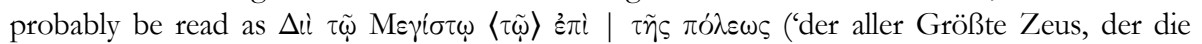
Aufsicht über die Polis hat'). The sacrifice took place on the altar of Zeus Soter; the epithet

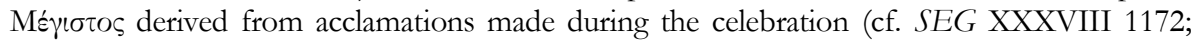
I.Stratonikeia 10) [on acclamatory epithets see infra $\mathrm{n}^{\circ} 36$ ]. Numerous other inscriptions of the Hellenistic and Imperial period are adduced as evidence for competition manifesting itself in festivals, including texts that refer to the rivalry among cult associations (the Iobakchoi inscription of Athens: $I G \mathrm{II}^{2}$ 1368) and civic subdivisions (a cult regulation from Bargylia: SEG XLV 1508; XLVIII 1328); the competition of new benefactors with those of the past (cf. SEG XXXII 1243); festivals admired by neighbouring cities (MAMA VIII $492 \mathrm{~B}$ ); and the revival of local traditions (cf. SEG XXIX 807; XXXII 1243).

36) A. Chaniotis, "Acclamations as a Form of Religious Communication", in Religion des Imperium Romanum, p. 199-218: At festivals, the attention of the invited gods was attracted 
through signals that could be seen (bright clothes, crowns, animals with gilded horns, decorated altars, tables, klinai), smelled (incense, wine, and thighs burning on the altar), and heard (hymns, prayers, invocations, musical performances, acclamations). As acoustic signals in

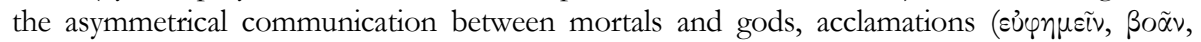

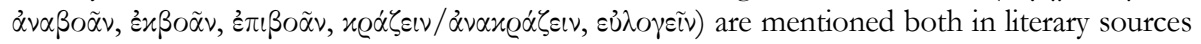
(e.g. Acta Apost. 19, 34) and in inscriptions (e.g. Delphi: SEG LI 613-631; EBGR 2001, 150). Acclamation occurred both spontaneously, especially after people had experienced a divine epiphany (e.g. I.Stratonikeia 10; Ael. Arist., Hieroi Logoi IV, 50), and in the context of rituals, especially in rituals of propitiation (BIWK 9-11, 37, 47, 55, and 72; SEG LIII 1344), ceremonies (TAM V.1.75; I.Magnesia 100 line 41), and mystery cults (IGUR 192; Lucian, Alex. 38). Most

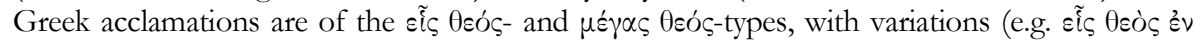
oủeavoĩc). Not every reference to heis theos refers to a single god, whose existence excludes that of other gods; often this phrase designates a singular, unique, or superior god in a polytheistic system. Although acclamations were, in theory, addressed to gods, they were primarily intended to impress audiences of mortals assembled in sanctuaries or other ceremonial spaces (e.g. the sanctuary of Asklepios on the Insula Tiberina in Rome: IGUR I 148). Acclamations expressed not only the superiority of one god over others (e.g. SEG LI 613-631; cf. SEG

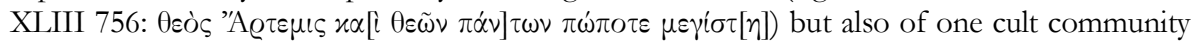
over others (e.g. the acclamations of the Iobakchoi in Athens: IG II ${ }^{2}$ 1368; LSCG 51). Acclamations performed in the context of mystery cults marked the acceptance of a new member or the graduation from one level of initiation to the next (e.g. P.Gurob 1; P.Oxy. XI.1382; graffiti and dipinti in the Mithraea of the Church of Santa Prisca in Rome and in Dura-Europos: M.J. VERMASEREN - C.C. VAN ESSEN, The Excavations in the Mithraeum of the Church of Santa Prisca in Rome, Leiden, 1965, p. 179-240; F. CUMONT - M.I. RosTOVTZEFF, "Dipinti and Graffiti", in M.I. RostovTZEFF et al. (eds.), The Excavations at Dura-Europos VII/VIII, New Haven, 1939, p. 87, 120). Religious acclamations also gave public testimony to the power of a god and confirmed the worshipper's faith; they propitiated the god after a misdemeanour and served as a warning to others; they enhanced emotional intensity during celebrations. Since they were performed in public, they also contributed to the dissemination of similar formulations throughout the Roman East. A connection can be drawn between acclamations and a particular group of epithets given to gods ('acclamatory epithets'). Unlike epithets that derive from a place name (e.g. Klarios), express a specific quality of a deity (e.g. Chthonios), refer to a ritual in the cult of a divinity (e.g. Thesmophoros), or allude to the merging of a Greek and a prehellenic god (e.g. Apollo Maleatas), from the Hellenistic period onward epithets that praised in very general terms a divinity and its power as benevolent,

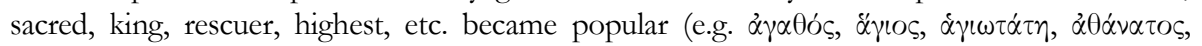

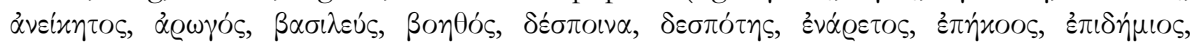

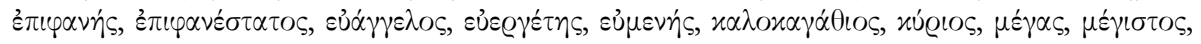

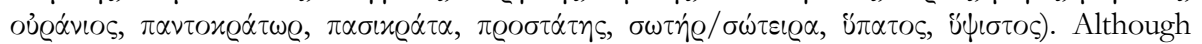
mainly attested in the Imperial period, acclamations are of more ancient origin. The invocation $\dot{\alpha} \gamma \alpha \theta \tilde{n} \tau \dot{\chi} \chi \eta$ ('for good fortune') in inscriptions reflects oral performances during the assembly;

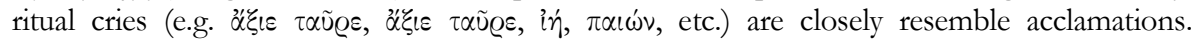
Acclamations must have also been practiced when worshippers approached a divine image

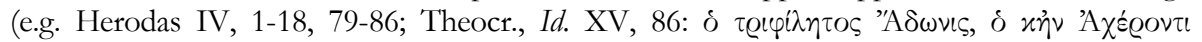
$\varphi(\lambda \eta \theta \varepsilon i \varsigma)$.

37) A. Chaniotis, “The Dynamics of Rituals in the Roman Empire”, in Ritual Dynamics, p. 329: Primarily exploiting the epigraphic material from the Roman East, this article provides examples of how Roman expansion influenced the development of rituals in the Roman Empire. The following phenomena are examined: ritual displacement (the transfer of a ritual 
from one context to another); the ritual agency of representatives of Rome (arbitration and involvement in religious controversies, introduction of rituals); ritual transfer caused by increased mobility within the empire; and the emulation of rituals and the use of rituals in the competition between cities [cf. infra no 35]. These developments are exemplified by phenomena such as Roman intervention in the dispute concerning the sanctuary of Sarapis on Delos (I.Délos 1510); the review of the claims of Greek sanctuaries to asylia in 22/23 CE (Tacitus, Annales 3.60.1-3); the award of neokoreia and the approval of the imperial cult (cf. SEG XI 922); measures concerning the funding of rituals; the diffusion of 'divine words' (the Sibylline and other oracles, the theological oracle of Klaros); the diffusion of the cult of Theos Hypsistos and ritual practices connected with this cult (the lighting of fire on altars and lamps); the development of a koine in rituals and in magic (hymnody, dissemination of magical handbooks, the cession of lost or stolen property to a god, prayers for justice); the introduction of Roman rituals such as the rosalia/rhodismos and the Compitalia in the provinces, and of Roman cults in the Roman colonies; the transfer of rituals from one context to another (rituals of the worship of the gods used as a model for the imperial cult); local rituals as a promoter of local identity. The religious and cultural changes in the Roman Empire are the result of complex processes for which the term 'Romanization' is inadequate.

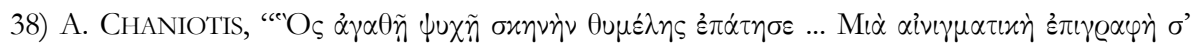

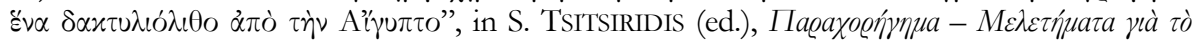

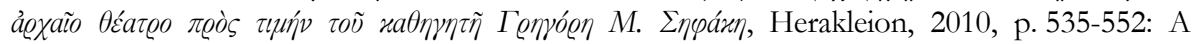
hematite gem from in Egypt (A. DELATTE - P. DERCHAIN, Les intailles magiques gréco-égyptiennes, Paris, 1964, p. 335f. no. 514, 3rd cent. CE) is decorated with a naked winged figure (Eros?) seated on a fish. The fish incorporates the head of a griffon and the profile of a man; the lower part of the fish terminates in a cock. Under this image, there is an eagle clenching a liver snatched from an altar. The image finds parallels in the iconography of Nemesis. The

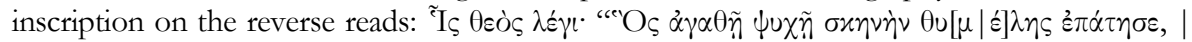

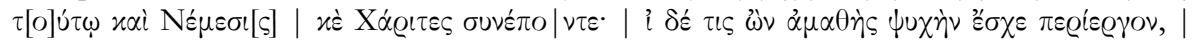

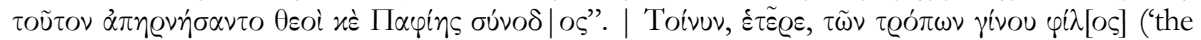
one god says: "Whoever stepped on the stage of thymele with a virtuous soul is followed by Nemesis and the Graces; if, however, someone who lacks knowledge has a curious/indiscrete soul, the gods and the synod of the Paphian goddess have renounced him." So, companion,

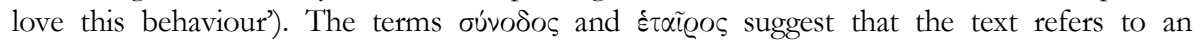
association; thymele alludes to musical or theatrical performances; Nemesis and the Graces allude to contests and victory. Therefore, the gem must be related to the theatre, and probably to the Dionysiac artists who had their seat in Paphos, on Cyprus. According to this

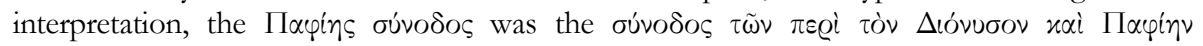

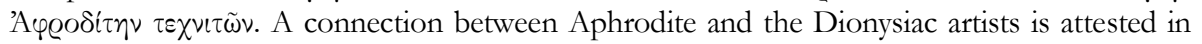

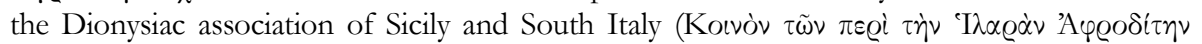
$\tau \varepsilon \chi \nu \imath \tau \tilde{\omega} \nu$; see EBGR 2000, 5). The text, which possibly predates its inscription on stone,

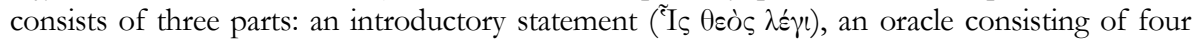
hexameters, and an iambic trimeter providing moral instruction to the club's members. The god involved was probably Apollo, whose moralizing oracles are common from the 2nd cent. CE onwards. This object, perhaps given to an actor as a token of membership, prescribes moral qualities as a requirement for membership in the Dionysiac association. It criticizes lack of knowledge combined with curiosity, indiscretion, or overwrought behaviour ( $\omega_{\nu} \dot{\alpha} \mu \alpha \theta \dot{\eta} \varsigma$

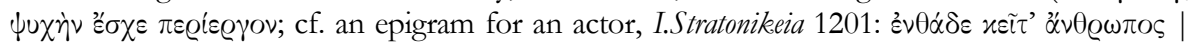

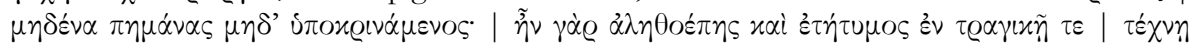

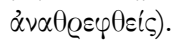


39) A. Chaniotis, "Aphrodite's Rivals: Devotion to Local and Other Gods at Aphrodisias", CCG 21 (2010) [2011], p. 235-248 [BE 2012, 383]: The public inscriptions of Aphrodisias reveal a community dominated by the city's eponymous goddess, Aphrodite. Different expressions of religious sentiment are observed in the private dedications to deities other than Aphrodite, which are collected and presented in an appendix: 1) A dedication to Koure Plyaris (IAph2007 8.209, Hellenistic), whose epithet derives from the local toponym Plyara. 2) A dedication to Zeus Nineudios by a smith (SEG LIV 1037, 1st cent.; the statuette of an eagle). 3) A dedication to an anonymous god (LAph2007 8.207, 1st century BCE/CE). 4) A building inscription recording the dedication by the priest of Plouton and Kore of a temple, statues,

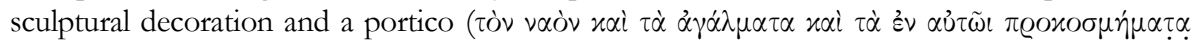

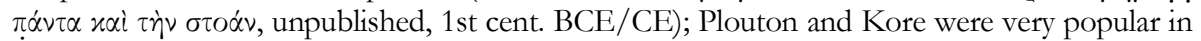
Karia. 5) An inscription recording the erection of a building for Zeus Spaloxios and Zeus Patroios by their priest (unpublished, early 1st cent. CE). 6) A dedication to Zeus Spaloxios in accordance with his command $([x] \alpha \tau \dot{\alpha} \varepsilon z \pi \tau \alpha \gamma \grave{\eta}[\nu]$; J and L. ROBERT, Fouilles d'Amyzon en Carie I, Paris, 1983, p. 166 no 27, Imperial period). The epiklesis Spaloxios derives from the local place name Spaloxa. 7) A dedication to Zeus Nineudios by a woman on behalf of her son (i் $\dot{e} \varrho . .$.

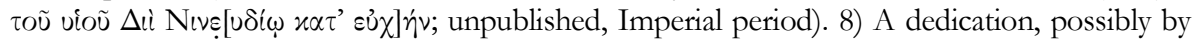
the same woman, to Zeus (certainly Nineudios; the votive is a statuette of an eagle; SEG LVIII 1187; EBGR 2008, 43). 9) A dedication to Zeus (certainly Nineudios; again, a marble statuette of an eagle; Imperial period; SEG LVIII 1186; EBGR 2008, 43). 10-11) Two dedications to Asklepios (1st and 2nd cent. CE; LAph2007 15.240: an anatomical votive, a panel with representation of a pair of eyes; $L A p h 2007$ 4.113). 12) An anatomical votive (an altar with a representation of breasts in relief) dedicated (to Asklepios?) by a man for his wife (IAph2007 11.3, Imperial period). 13) An anatomical votive (votive panel with a representation of breasts) dedicated by a woman to Asklepios (IAph2007 5.112; 2nd cent. CE). 14) A dedication to Theos Hypsistos (IAph2007 2.516, Imperial period). 15) A dedication to an anonymous

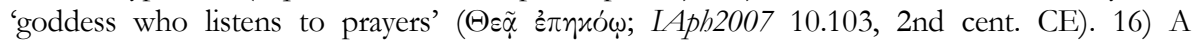

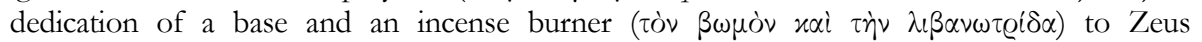
Thynnaretes by two slaves, the agents of a knight (unpublished, 2nd cent. CE.). The dedication

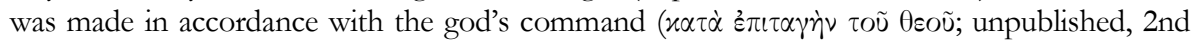
cent. CE). Thynnara is indirectly attested as the earlier name of Synnada in Phrygia, whose eponymous founding hero was Thynnaros. Aphrodisias and Synnada produced marble, which explains the presence of the two agents from Synnada in Aphrodisias. 17) A dedication to

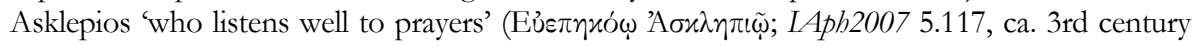
CE; a panel with a representation of breasts in relief). The rare epithet $\varepsilon \dot{v} \varepsilon \pi \dot{\eta}$ นoo was used in order to intensify the expression of piety. 18) A dedication 'to the goddess who listens' ( $\theta \alpha i \tilde{\alpha}$

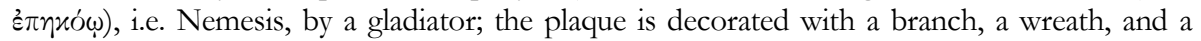
pair of ears in relief (SEG LVI 1191, 3rd cent. CE); later, a second gladiator rededicated this votive. Apart from the building inscriptions (4-5), the dedicants were members of the lowest classes, who never mention the name of their father. Their dedications differ from those of magistrates and from dedications of buildings with respect to the recipients (a variety of deities other than Aphrodite) and to the display of religious sentiments. All of them allude to the fact that they were made after a personal communication with a god: in fulfilment of a vow, i.e. after the god had responded to a prayer $(1-3,7,8,10-14$, and 17; cf. 15, 17, and 18:

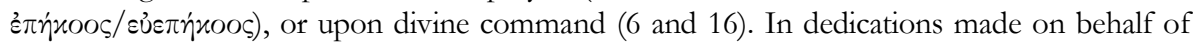
relatives (7 and 12), the dedicants' motivation was affection and not the personal display of wealth and power. The dedications were addressed to local gods (Zeus Nineudios, Zeus Spaloxios, Kore Plyaris, Plouton and Kore) and to deities that became popular in the course of the Hellenistic and Imperial period (Asklepios, Theos Hypsistos, and Nemesis). Most dedications to local gods are concentrated in the 1st cent. BCE/CE, a period in which 
Aphrodite had not yet become the sole divine patron of the city and Aphrodisias was still developing into the only urban centre in the area.

40) K.G. Chatzinikolaou, "Locating Sanctuaries in Upper Macedonia According to Archaeological Data", Kernos 23 (2010), p. 193-222: C. collects the evidence for sanctuaries in Upper Macedonia (Elimea, Eordaia, Lynkestis, Orestis) and their topography. Sanctuaries are located in urban centers, on the crests of hills or on mountaintops (Zeus Hypsistos), at hubs (Apollo), and in passages (Ennodia). The collected evidence concerns the cults of Apollo, Artemis Ephesia, Athena, Dionysos, Ennodia, Hekate, Herakles, Plouton, Pasikrata, Zeus, and Zeus Hypsistos.

41) T. Corsten, "Die Grabinschrift des Priesters Albasis in Myra", Adalya 11 (2008), p. 99107: [SEG LVIII 1605]: C. republishes the epitaph of a priest from Myra (2nd cent.; A.-

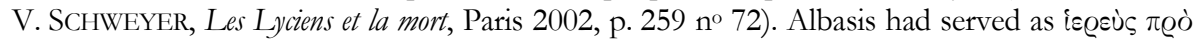

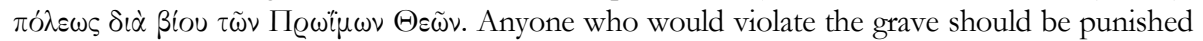

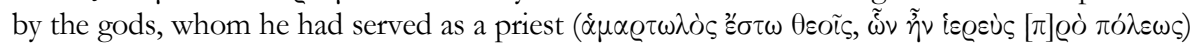

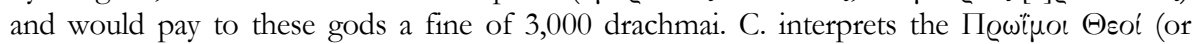

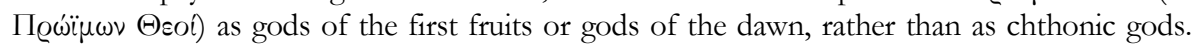

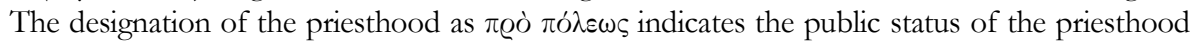
rather than the location of the cult outside the city walls [on the cult and the priesthood see infra $\left.\mathrm{n}^{\circ} 175\right]$.

42) T. CORSTEN, "Ein Epigramm für Poseidon als Gott der ländlichen Fruchtbarkeit", Adalya 9 (2006), p. 53-61 [SEG LIV 1399]: Ed. pr. of a dedicatory epigram from the area of Kibyra (ca. 150 CE; cf. MERKELBACH - STAUBER, SGO V 44/45 no 24/30; T. CORSTEN, "Estates in Roman Asia Minor: the case of Kibyratis", in S. MitCHELL - C. KATSARI (eds.), Patterns in the Economy of Roman Asia Minor, Swansea, 2005, p. 41f.). The epigram was dedicated to Poseidon Epekoos by L. Marcius Celer, either the consul suffectus of 135-138 or 148 CE or a relative. The text of the epigram, written (by Longos?) in high style and using rare words, refers to a sacrifice offered by Longos to the Nymphs and Poseidon after a hunting expedition in the mountains. The poem ends with a prayer in which Longos asks the Nymphs to protect his

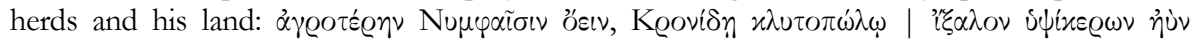

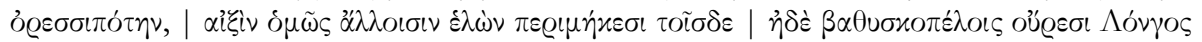

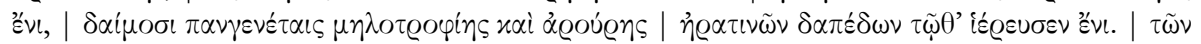

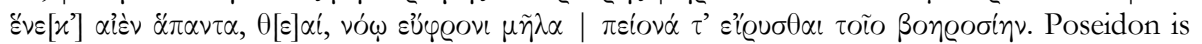
worshipped here as a patron of rural fertility. His sanctuary may be the find-spot of this and two other dedications. [Stricto sensu, only the Nymphs are patrons of fertility; only they are invoked in the prayer. What did Longos sacrifice? Longus opferte den Nymphen, dem Kroniden (Poseidon) mit den edlen Rössern, ein wildes Schaf, springend, mit hohen Hornern, mutig, in den Bergen trinkend, welches er, zusammen mit anderen Ziegen, in diesen sehr hohen Bergen mit hohen Klippen jagde' (Corsten's translation). O. SALOMIES, Année Épigraphique (2004) [2007], no. 1473, rather sees two sacrifices being performed: 'pour les Nymphes une brebis sauvage; pour le Cronide aux illustres coursiers, un noble bouquetin aux hautes cornes'. His interpretation is to be preferred. The Nymphs received a female victim (a wild ewe), Poseidon a male one (a wild he-goat). To catch a wild goat alive and to bring it (wounded) to the altar is a difficult task, attested as a rite of passage in Archaic Crete (see A. Chaniotis, "Extra-urban Sanctuaries in Classical and Hellenistic Crete", in G. DeLigianNAKIS - Y. GALANAKIS (eds.), The Aegean and its Cultures, Oxford, 2009, p. 61, with bibliography). My translation: 'Longos sacrificed to the Nymphs a wild ewe, and to Kronos' son, the one with the noble horses, a wild he-goat with high horns, brave, who drinks water on the mountains. He captured it together with other wild goats on these high mountains with the 
steep cliffs. (He offered the sacrifice) in these lovely grounds to the deities of herding and of the land, who give birth to everything. For this, goddesses, with a benevolent mind preserve his sheep and his fertile land'].

43) S. CRIPPA - M. De SIMON, "Sulla valenza pubblica dei rituali defissori a Selinunte", in Temi selinuntini, p. 93-104: The formulations used in the defixiones from Selinous, mostly deposited in the sanctuary of Malophoros (see L. BETTARINI, Corpus delle defixiones di Selinunte, Alessandria, 2005; EBGR 2005, 16), reveal an influence from public documents: the use of the invocation $\Theta \varepsilon \dot{\alpha}$ (BETTARINI no 1); abbreviated names like those found in lists of individuals ( $\left.n^{\circ} 27\right)$; the arrangement of names into columns ( $\mathrm{n}^{\circ} 14$ ); and the use of the paragraphos ( $\mathrm{n}^{\circ \mathrm{s}} 5,13$ ). The adaptation of scribal practices deriving from official documents imparted an official character to the Selinuntian curses. [This interesting observation also applies to material from other places; see EBGR 2008, 82, for the use in defixiones of symbols of authority from real life. As in records of divine punishment, the justice of gods is assimilated to secular justice (cf. EBGR 2009 , 33). It seems that in some defixiones the prosecution of an opponent by means of a curse was formally likened to actual prosecution].

44) L. D'AMORE, "Dediche sacre e ginnasi: la documentazione epigrafica di età ellenistica", in Dediche sacre, p. 161-180: D. presents a useful overview of dedications in Hellenistic gymnasia. Such dedications were made by officials (gymnasiarchoi, ephebarchoi, etc.), instructors, attendants of the gymnasion, parents of victors, private citizens, and kings. The dedications were offered not only to divinities associated with the gymnasion (Hermes, Herakles, Apollo, the Muses, etc.) but also to a wide range of divinities (patrons of health, civic gods, etc.). The dedications varied: common objects were prizes of contests, altars, divine images, statues of kings, honorific statues, herms, catalogues of members of the gymnasion, and ephebic cloaks. The motivation of the dedicants was primarily social display.

45) M. DANA, "Cultes locaux et identité grecque dans les cités du Pont-Euxin", LEC 75 (2007), p. 171-186: Focusing on epigraphic evidence from Chersonesos in Tauris, Olbia, and Histria, D. gives an overview of the ways in which local cults and the epiphanies of patron gods (Parthenos in Chersonesos, Achilles in Leuke and Berezan) were used in order to shape local identity in the cities of the Black Sea. With regard to Parthenos in Chersonesos (p. 173177), she discusses the honorary decree of the city for the local historian Syriskos, who had treated Parthenos' epiphanies (IOSPE I2 344; French translation); the decree of Herakleidas in honour of Parthenos, who had saved the participants of a Dionysiac procession from a barbarian attack (IOSPE I ${ }^{2} 343$ ); and the decree in honour of Diophantos, which refers to an epiphany of Parthenos (IOSPE I2 352). In default of a long history, the Chersonesitans exploited the miracles of Parthenos in order to promote the local political and religious identity. On p. 174/175, D. collects inscriptions in honour of gods for their epiphanies (I.Magnesia 61 = OGIS 233; I.Pergamon $248=$ OGIS 331 IV 52 [D.’s reference (332) should be corrected (331)]; Syll.3 867: cf. I.Lindos 2; SEG XXVIII 543; IG XII.5.812). In the area of Olbia,

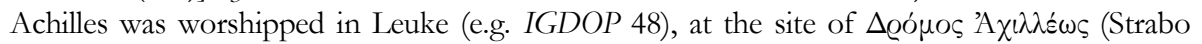
VII, 3, 19; cf. the reference to an equestrian contest in IOSPE I2 34), and in Berezan (cf. SEG XL 610). Milesian colonists probably introduced the worship of Achilles, but in this area his

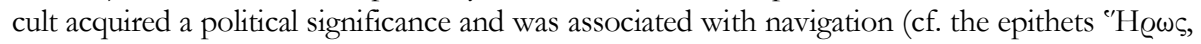

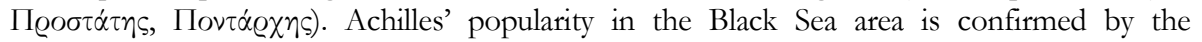

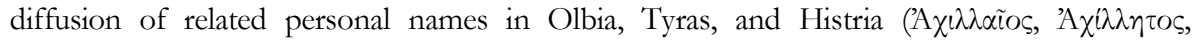

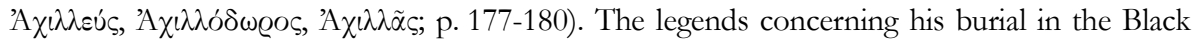
Sea on the one hand gave the hero a resting place at the margins of the Greek world and, on the other, helped integrate this area into the world of the Greek legends (p. 186). The local significance of the cult of Apollo Ietros, attested in Olbia (IGDOP 58), can be inferred from 


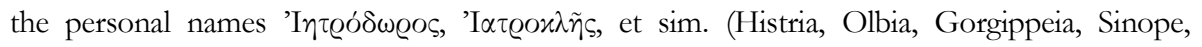
Kallatis, Pantikapaion), which are also common in Miletos and Ionia, where direct evidence of the cult has not yet been found (p. 181). Finally, an interest in local cults is revealed by the

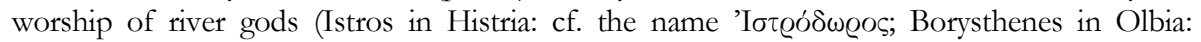

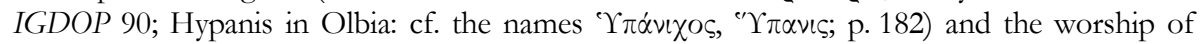
founder heroes, such as Autolykos and his brothers Deileon and Phlogios in Sinope (cf. I.Sinope 62) [see infra no 60]; Herakles was also regarded as a founder of Sinope (IG XIV 1293 lines 101f.: cf. I.Sinope 112). The existence of two foundation legends, one mythical and the other more recent, is common in Greek colonies.

46) V. DASEN, “Une 'Baubô' sur une gemme magique”, in Chemin faisant, p. 271-284: D. gives an overview of uterine amulets and their iconography and presents an unpublished gem of red cornelian in a private collection. The obverse is decorated with an image of a naked female figure with raised arms and the legs widely splayed; she can be identified as Baubo. A scarab is placed above her head and a thunderbolt under her feet. An ouroboros surrounds the image. An inscription is engraved on the reverse: BAKXA|PIBPA $\mid \Theta I B I$. The gem had a prophylactic function and promoted fertility.

47) J.K. Davies, "Pythios and Pythion: The Spread of a Cult Title", in Greek and Roman Networks, p. 57-69: D. gives a general summary of the pre-Hellenistic attestations of 'A $\pi$ ó $\lambda \lambda \omega \nu$ Пú epithet is primarily attested in Attica, the Argolid, Thessaly, the Aegean islands (especially Crete), and a few cities in Asia Minor (Ephesos, Erythrai, Klaros, Mylasa). Possible explanations for this diffusion, none of them entirely satisfactory, are the crystallization of the Amphiktyony around the sanctuary at Delphi and the association of Apollo Pythios with divination and purification.

48) P. Debord, "Notes d'épigraphie clarienne, I", REA 112 (2010), p. 275-294 [BE 2011, 508]: Ed. pr. of two Hellenistic citizenship decrees of Kolophon found in the sanctuary of Apollo Klarios. They mention the privilege of access to the magistrates, the council, and the

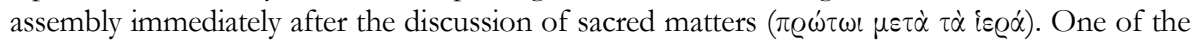
decrees preserves the publication clause: it should be placed in the sanctuary of Apollo Klarios.

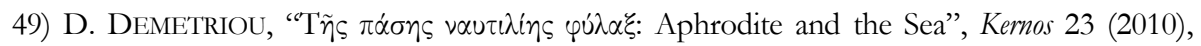
p. 67-89: A series of Hellenistic epigrams (AP IX, 143, 333, 144, 601; XVI 249; Poseidippos ep. 116 and 119 edd. Austin/Bastianini; Philodemos 8 ed. Sider, etc.) evinces the perception of Aphrodite as a divine patron of seafaring. This is consistent with the epigraphically attested epithets Euploia, Epilimenia, and Pontia. Aphrodite's cult as patron of traders and sailors is also attested through dedications (IG XIV 401; I.Délos 2305; SEG XXXVI 798; cf. Iscr.Cos ED 178 a and SEG L 766). This explains why her sanctuaries were often located near harbors.

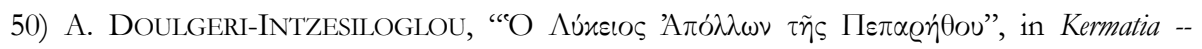
Touratsoglou II, p. 471-479 [SEG LIX 972]: Ed. pr. of a marble block with the inscription

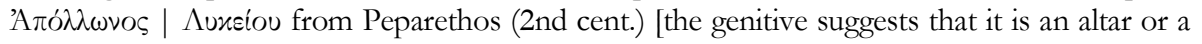
boundary stone]. D.-I. collects and discusses the literary and archaeological evidence for the cult of Apollo in Peparethos.

51) R.G. Edmonds, "Who Are You? Mythic Narrative and Identity in the 'Orphic' Gold Tablets", in Mystic Cults in Magna Graecia, p. 73-94: E. examines the narrative that underlies the Orphic texts, recognizing three crucial aspects: obstacle (the confrontation of the deceased with Persephone, whom the deceased initiate approaches as a suppliant); solution (proclamation of the deceased initiate's identity and reference to his status of purity, the atonement of 
sin, and his lineage); and result (afterlife). The texts place an emphasis on the 'solution', i.e. the identity of the initiate.

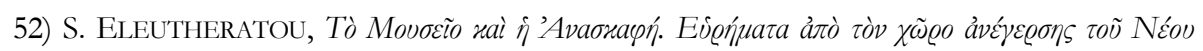

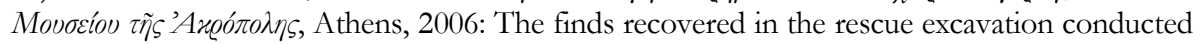
during the construction of the New Acropolis Museum include a black-glazed kantharos of the

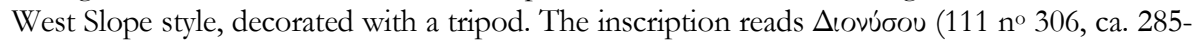
275) [the vase was used for libations to Dionysos].

53) H. Engelmann - T. Korkut, "Eine Inschrift aus Patara", in T. TAKOĞLU (ed.), Anadolu Arkeolojisine Katkılar. 65. Yassinda Abdullab Yaylaliya Sunulan Yaz̨lar, Istanbul, 2006, p. 307-312 [SEG LVIII 1613]: Ed. pr. of a list of members of the elite who had been selected by a

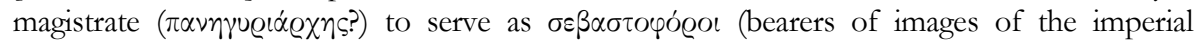

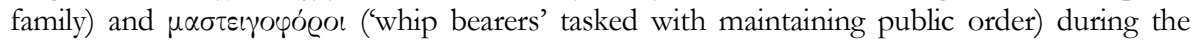
celebration of a festival (Patara, Imperial period).

54) F. EtruĞRul - H. Malay, "An Honorary Decree from Nysa”, EA 43 (2010), p. 31-42 [BE 2011, 527]: Ed. pr. of a lengthy honorary decree for a woman, who offered extra-ordinary services to the sanctuary of Plouton and Kore in Nysa (1st cent. CE). First, Clodia Cognita is praised for her piety and for her contribution to the decoration of the sanctuary: 'As Clodia Cognita, daughter of Aulus, wife of Publius Vedius Demades, outstanding in temperance and

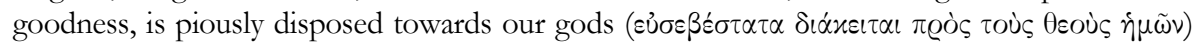

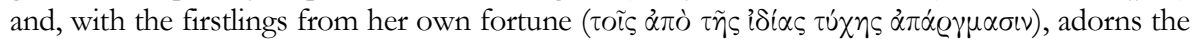
sanctuary and promised (sc. to equip the sanctuary) with golden and marine-blue (?) votive offerings and with all the other ones in a colourful way, neglecting nothing of what pertains to

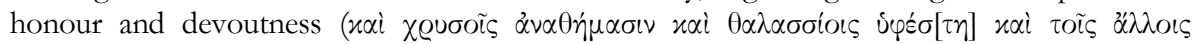

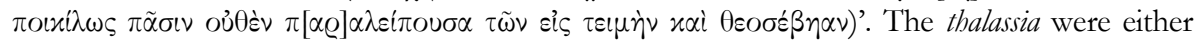
marine-blue objects or objects made of material originating from the sea (e.g. shell, coral, amber, precious stones). It seems that in the past, some of her dedications had been treated by the $\tau \varrho \alpha \pi \varepsilon \zeta \tilde{\omega} v \alpha \iota$ in a manner that had incited Cognita's complaints. The eds. interpret the hapax $\tau \varrho \alpha \pi \varepsilon \zeta \tilde{\omega} \nu \alpha \iota$ as 'people who were hiring out tables for cultic purposes', i.e. people who hired out equipment, in particular tables, including items dedicated by Cognita and her family. They translate the relevant passage as follows: 'the council, on account of her goodness in general and in particular of her devotion towards the gods ( what is being done (by her) and considers it just that they should remain (there) forever and that nothing from the offerings brought by Cognita to the gods should be carried away

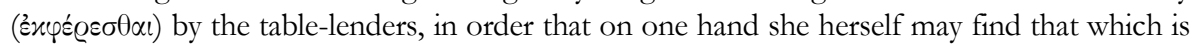

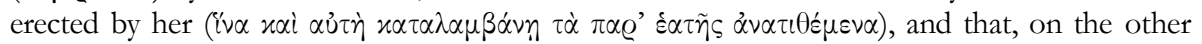
hand, these object, through their presence, may serve as encouragement to the others to adorn the gods' [n my view, the $\varrho \alpha \pi \varepsilon \zeta \tilde{\omega} v \alpha \iota$ did not hire out tables but leased them from the city; as the $\theta \varepsilon \alpha \tau \varrho \tilde{\omega} v \alpha l$ were lessees of theatres and the $\delta \eta \mu o \sigma i \tilde{\omega} v \alpha l$ were leased revenues, the $\tau \varrho \alpha \pi \varepsilon \zeta \tilde{\omega} \nu \alpha \iota$ leased tables - more accurately: they leased the right to set up trapezai-, paying an amount to the city and acquiring the right to exploit them. The trapezai that they exploited must have been offering tables, probably for bloodless sacrifices. It seems that the trapezonai removed the tables that had been dedicated by Cognita and were meant to be available to worshippers for free (see below). For a similar view see P. HAMON, BE 2011, 527: 'les mises en adjudication par la cité, sous la forme d'enchères annuelles, d'une charge: peut-être de fournir les $\tau \varrho \alpha ́ \pi \varepsilon \zeta \alpha \iota$ en question']. The city took measures to prevent the removal of any of Cognita's dedications: (the council resolved) 'none of the objects offered to the gods by Cognita or her children or her husband to be carried away, but that, on one hand, the values (sc. which were due to the hiring out of Cognita's and her family's tables) are to be deducted (in retrospect) 
annually from the proceeds of the table-lenders; and that, on the other hand, from now on the hiring out of the tables should take place excluding those (tables), which are brought in for the gods by Cognita or her children or her husband, and that the contracts (sc. governing the hiring out of tables) complying with this condition are to be closed by providing a security; and if furthermore no one adds any written remark to these given securities, based on this decree,

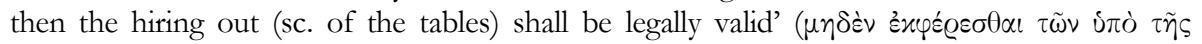

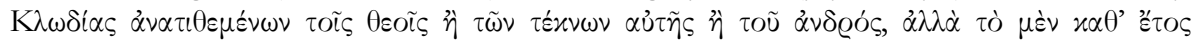

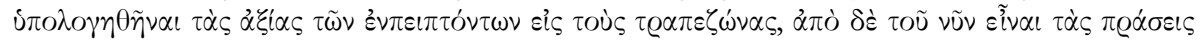

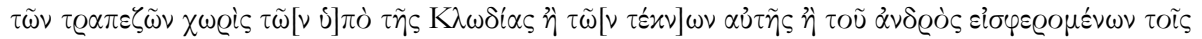

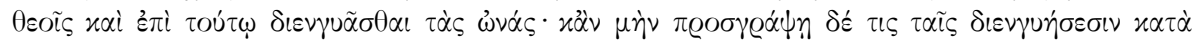

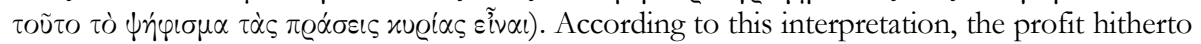
made by trapezonai with Cognita's gifts was to be annihilated. The values of their hiring were to be deducted from their income. [The Greek formulation needs further study. It seems that with the $\mu \varepsilon^{\prime} v / \delta \dot{\varepsilon}$ construction the author of the decree distinguishes between the future ( $\dot{\alpha} \pi \grave{\partial} \delta \dot{\varepsilon}$

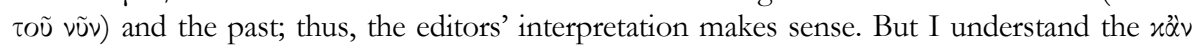
$\mu \grave{\eta} \nu \pi \varrho \circ \sigma \gamma \varrho \alpha \dot{\psi} \eta n$ in a different manner: 'and even if one does not add any written statement (to this effect) in the documents recording the securities, nevertheless the hiring out (of the tables) shall be legally valid in accordance with this decree]. Then the decree refers to the latest of Cognita's dedications, an altar: 'the marble altar, which Cognita has had made for the gods, shall be erected untaxed in a place in the pronaos'. The decree and a list of the offerings made by Cognita and members of her family were to be inscribed on this altar. Cognita was honoured with a painted portrait on a gilded shield, which was placed in the temple of Plouton and Kore. Below the decree, a list of Cognita's offerings was inscribed: 'Golden objects offered to Kore by Cognita: a perimyrton, earrings set with precious stones, a gorget set with precious

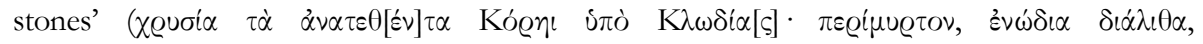

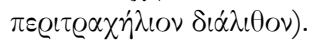

55) C.A. FARAone, "Notes on Some Greek Amulets", ZPE 172 (2010), p. 213-219 [BE 2011, 63]: 1) Ed. pr. of an inscribed octagonal bronze ring of unknown provenance (Cabinet des Médailles, Late Antiquity). The text is a version of a previously known incantation: $\theta \varepsilon(\grave{o} \varsigma)$

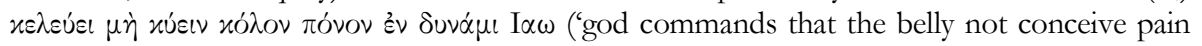

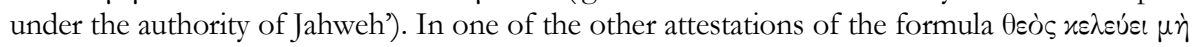

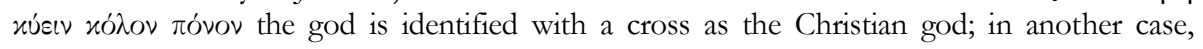

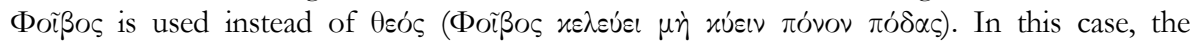

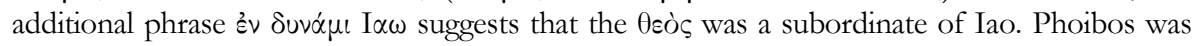
associated with this incantation as an oracular god (cf. Pliny, NH XXVI, 93: negat Apollo pestem posse crescere cui nuda virgo restinguat). 2) The correct reading of a gem in the collection of M. SommerviLe, Engraved Gems: Their History and Place in Art, Philadelphia, 1889, p. 767

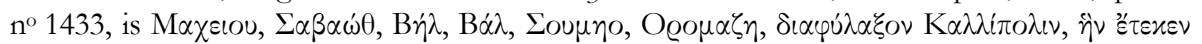
K $\alpha \lambda \lambda i$ irodıc. 3) The image on the obverse of a hematite gem (C. WAGNER - J. BOARDMAN, $A$ Collection of Classical and Eastern Intaglios, Rings and Cameos, Oxford, 2003, $\mathrm{n}^{\circ}$ 577) can be interpreted as a reclining Aphrodite; the inscription around this image is an (Egyptian?) magical formula aiming to arouse attraction; the erotic context is confirmed by the magic word

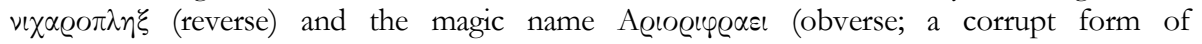

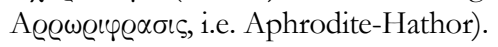

56) C.A. Faraone, "A Greek Magical Gemstone from the Black Sea: Amulet or Miniature Handbook?”, Kernos 23 (2010), p. 91-114 [BE 2012, 68]: F. discusses a large spherical gemstone of agate kept in the Anapa Museum, probably from Gorgippia (Imperial period; O.Y. NEverov, "Gemmes, bagues et amulettes magiques du Sud de l'URSS", in Hommages à M.J. Vermaseren, Leiden, 1978, II, p. 833-848 no 50). The inscription on the obverse bears the 


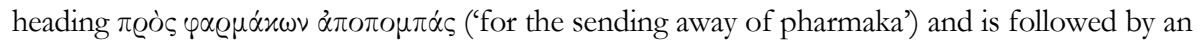
expulsion formula: a magical formula and the name Damnameneus written ten times in the form of a triangle; with each successive line one letter is left off. The text on the reverse starts

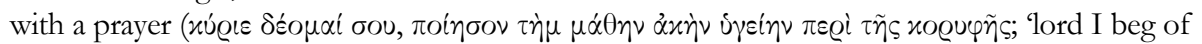
you grant the knowledge, healing, health, concerning the head') followed by a list of parts of the head (brain, ears, eardrum, uvula, throat, forehead, nostril, polyp, teeth, mouth) accompanied by magical symbols and magical words. F. argues that this gem was not an amulet but rather a miniature handbook and a model for making a variety of amulets for healing various diseases of the head.

57) N.F. Fedoseev, “Graffiti Bospora iz pod vody”, Drevnosti Bospora 13 (2009), p. 457-472 [SEG LIX 852]: A large number of vases with graffiti found at Pantikapaion includes a

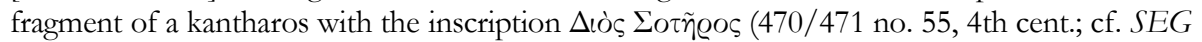
XXVII 437b; LVIII 749) [for the use of these cups in libations, see EBGR 2007, 6, Chaniotis].

58) H.-L. Fernoux, "Frontières civiques et maitrise du territoire: un enjeu pour la cité

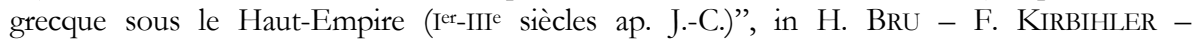
S. LEBRETON (eds.), L'Asie Mineure dans l'Antiquité : échanges, populations et territoires. Regards actuels sur une péninsule (Actes du colloque international de Tours, 21-22 octobre 2005), Rennes, 2009, p. 135164: In a study of the importance of territorial disputes in Asia Minor during the Imperial period, F. briefly addresses the importance of rural sanctuaries for territorial claims (p. 153156). In this context he adduces a dedication of a shrine of Meter Theon Oreia and the Fatherland by a police commander (paraphylax) on the frontier Apollonia of Salbake (L. ROBERT, Études anatoliennes, Paris, 1937, p. 106-108) and a dedication to Ares on the frontier of Boubon (C. KoKkINIA, "The Inscriptions of Boubon: a Catalogue", in C. KoKKINIA (ed.), Boubon: The Inscriptions and Archaeological Remains. A Survey 2004-2006, Athens, 2008, no. 72).

59) C. FEYEL, "La dokimasia des animaux sacrifiés", RPh 80 (2006), p. 33-55: F. gives an

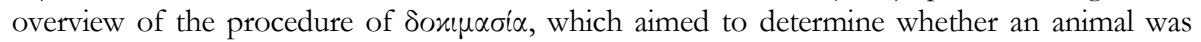
suitable for sacrifice. Adducing inscriptions and literary sources he discusses the criteria used in

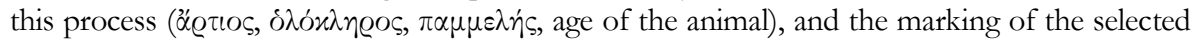

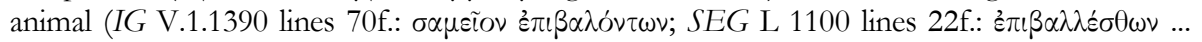

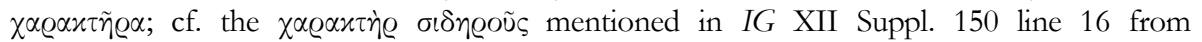

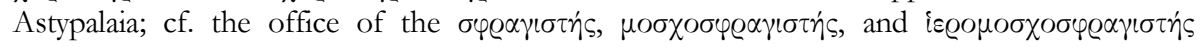
mentioned in papyri).

60) M. Firicel-DANA, "Traditions de fondation dans l'épigraphie de Sinope", REG 120 (2007), p. 511-525 [SEG LVII 1296 bis/ter]: The author republishes an inscription from Sinope (I.Sinope 62; SEG XLI 1141, 5th/4th cent.), which she plausibly recognizes as a dedication to the Phlogios, the hero who founded Sinope together with his brothers Autolykos and Deileon. Another inscription from Sinope (I.Sinope 173, Imperial period), which honors

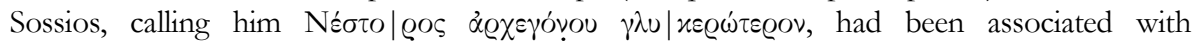
foundation legends. Nestor was the son of Neleus, the founder of Miletos, which in turn was the metropolis of Sinope. However, F.-D. points out that $\gamma \lambda u \mid x \varepsilon \varrho \omega$ is $\varrho \circ \varsigma$ refers to rhetorical

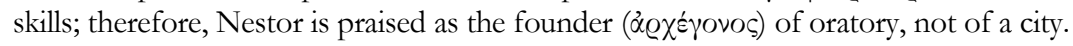

61) A. GANGLOFF, "Rhapsodes et poètes épiques à l'époque impériale", REG 123 (2010), p. 51-70: G. discusses the evidence for epic poets and rhapsodes in inscriptions of the Imperial period, including their participation in contests and festivals (p. 58-61). She discusses the case of P. Aelius Paion of Side [see also infra no 206]. According to L. ROBERT, "Deux poètes grecs

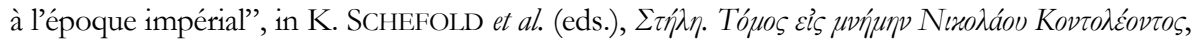

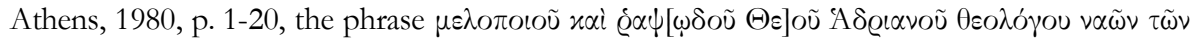




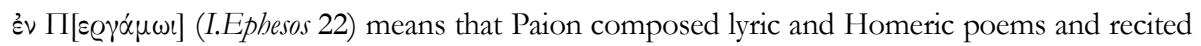
them for Hadrian. G. contends that the attribute theos rather indicates that Paion's activity was connected with the imperial cult (H. WANKEL, I.Ephesos XI.1., p. 138: 'Komponist und

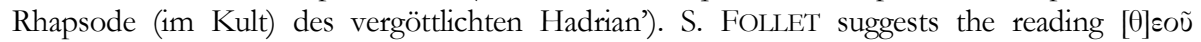

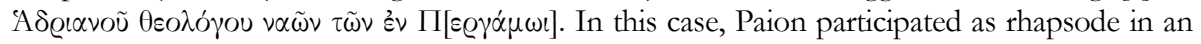
agon (the Pythia of Ephesos?) and was not a rhapsode of Emperor Hadrian. [There is no evidence that Paion was a victorious rhapsode and rhapsodic contests are not attested in Ephesos. In this inscription, Paion is first designated as $\pi$ ointท́s; it is thus with his activity as a

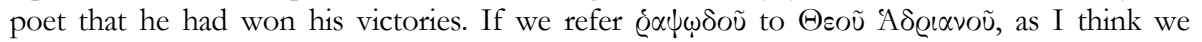
should, then Paion had composed melic and epic poems for the deified Hadrian. Exactly as

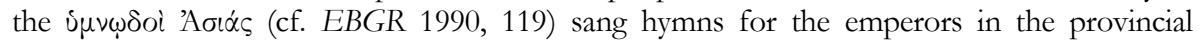

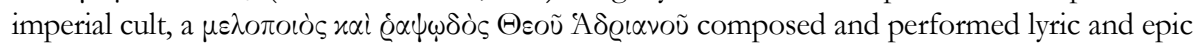
poems for Hadrian. Hadrian's hunting exploits, and possibly also his relationship to the deified Antinoos (cf. Achilles and Patroklos), offered enough subject matter for such poems, with which Paion could have earned the designation 'New Homer'. Hadrian himself composed a poem referring to his achievements in hunting (IG VII 1828; EBGR 2004, 102).]

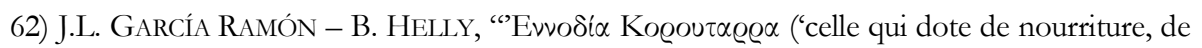
croissance') et autres divinités kourotrophes en Thessalie", RPh 81 (2007), p. 291-312 [BE

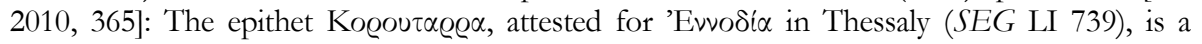

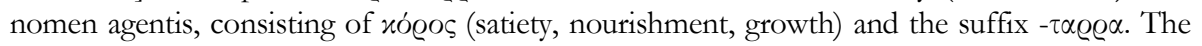
goddess is the one 'who makes grow' (*koroteria), i.e. the one who provides with nourishment. According to this interpretation, Ennodia was perceived as a kourotrophos, a property that she shared with other Thessalian deities (Apollo, Artemis Throsia, Akraia, Aspalis, Brimo, Hekate

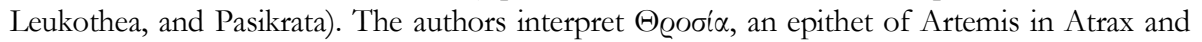
Larisa, as deriving from * $\theta$ @óøıৎ ('soutenir'; p. 305f.).

63) P.-L. GATIER, “Decapolitana”, Syria 84 (2007), p. 169-184 [SEG LVII 1873, 1931]: G. republishes a dedication from the area of Gerasa (98/99 CE; OGIS 620; p. 174-176). A

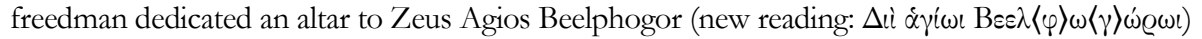
and Helios in fulfilment of a vow. G. identifies rock-cut dedications by soldiers in Petra as dedications to the same Syrian god (IGLS XXI.14 = SEG LIII 1907; 2nd/3rd cent.; p. 180-

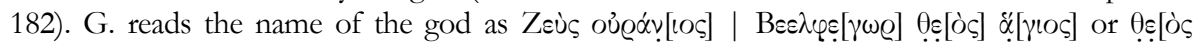
$\pi] \alpha[\tau \varrho \tilde{\varphi} \mathrm{O}$.

64) O. Gengler, “Une épingle pour Artémis Limnatis”, RA (2009), p. 53-68 [BE 2010, 260]: Two bronze objects dedicated to Artemis Limnatis (IG V.1.225-226), bought by P. Le Bas in Mystras in 1843, were probably found in the goddess' sanctuary at Volimos. One of them is a cymbal, the other the head of an Archaic fibula.

65) S. Giannobile - D.R. Jordan, "On the Text of the Hipponium Tablet", GRBS 48 (2008), p. 287-294 [SEG LVIII 1083]: The text on the Orphic tablet from Hipponion (SEG XXVI 1139) is a Doric version of an Ionic original. The many mistakes of the copyist occur in clusters, which suggests that he was using a damaged model written in stichoi. The errors are the result of the copyist's attempts to emend or to complete the damaged text. G.-J. tentatively

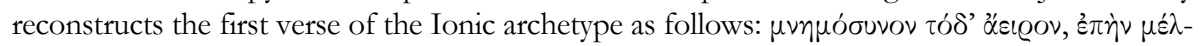

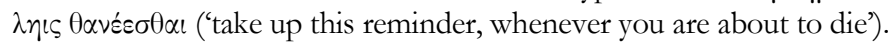

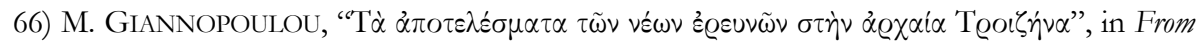
Mesogeia to Argosaronikos, p. 519-536: G. reports on new research in Troizen. The location of the sanctuary of Zeus Soter is identified (in the northwest part of the town), thanks to an old find, a stele [boundary stone?] with the inscription $\Delta$ iós (E. KONSOLAKI-GIANNOPOULOU, 


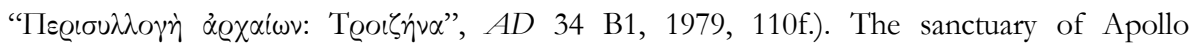
Platanistas has been located at the Lampousa Hill, where remains of a building and a lead weight with the inscription i $\ltimes \varrho 0 \tilde{~ w e r e ~ f o u n d . ~}$

67) N. GÖKAlp - E.N. AKDOĞU ARCA, “Antaly'dan Yeni Adak Yazitlari”, Adalya 12 (2009), p. 261-275: Ed. pr. of 9 dedications brought to the Museum of Antalya (Imperial period). All but two (8-9) were made in fulfilment of a vow. The recipients of the votives were the Dioskouroi (1), anonymous gods with the epiklesis epekooi (2), Herakles (3-4), Orda/Ourda or Ordas/Ourdas (5-6), an anonymous deity (7), Hermes, Artemis Kynegetis and the Twelve

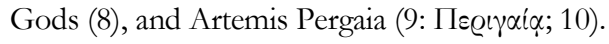

68) N. GÖLKAP - E.N. AKDOĞU, “Antalya'dan Yeni Yizitlar”, Olba 18 (2010), p. 281-306 [BE 2011, 43]: Ed. pr. of a door lintel inscribed with a dedicatory inscription (290f. no. 6), according to which Aurelius Demetrios dedicated to Apollo, Artemis, and Leto $\tau o ̀$ $\pi \varepsilon \varrho \iota \lambda i \omega \mu \alpha$

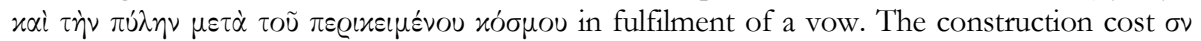
denarii (3rd cent. CE). The stone was found in Antalya, but the authors suspect a provenance from the Letoon of Xanthos [non vidimus; see the summary by M. SĖVE, BE 2011, 43. S. points out that the construction was not a portico, as stated by the authors, but a doorframe, a monumental gate, and the accompanying decoration. The expense of 250,000 denarii is explained by the great scale of the works.]

69) Gormy and Mosch, Giessener Münz̧andlung, Auktion 15. Dezember 2004. Antike und islamische Kunst 137, Giessen, 2004 [SEG LIV 1782]: When we presented objects from this catalogue in EBGR 2004, 100, we omitted a dedication of unknown provenance $\left(129 \mathrm{n}^{\circ} 488\right.$, 2 nd cent. CE). It is an altar dedicated to Hermes by Philostorgos after the completion of his term as

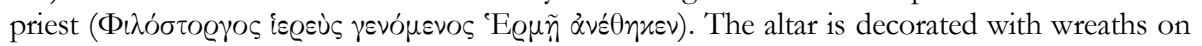
the lateral sides and a relief bust of Hermes with a kerykeion behind his back on the front.

70) Gorny and Mosch, Giessener Münzhandlung, Auktion Kunst der Antike 140, 21. Juni 2005, Giessen, 2005 [SEG LV 1885]: The objects offered for sale (of unknown provenance) include the following items (the texts were read by R. Tybout in SEG): 1) Agate gem with a representation of Harpokrates on a lotus flower and the inscription I $\alpha \omega \sum \alpha \beta \alpha \omega$ (85 no. 234; 2nd cent. CE). 2) Jasper gem with Anubis on the obverse and the palindromic text $\alpha \beta \lambda \alpha \nu \alpha \theta \alpha \nu \alpha \lambda \beta \alpha$ on the reverse (87 no. 242 ; 2 nd cent. CE).

71) P. Goukowsky, Études de philologie et d'histoire ancienne. I. Macedonica varia, Nancy, 2009 [BE 2011, 411, 415]: One of the chapters in G.'s book is dedicated to Dionysos' epithets 'Ayeros,

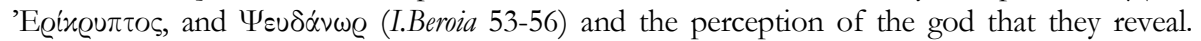
Emphasising the element of deception and illusion ( $\dot{\alpha} \pi \dot{\alpha} \tau \eta)$ in military contexts, G. argues that Dionysos was associated with $\alpha \pi \dot{\alpha} \tau \eta$ due to perceptions of him as an adolescent man (p. 6190). With regard to the terms $v \varepsilon \dot{\sigma} \sigma \alpha \sigma \alpha$ and $\alpha \varrho \chi \imath v \varepsilon v \dot{\sigma} \alpha \sigma \alpha$, which are attested in two dedications from Lete (SEG XLIV 535-536), G. proposes a different interpretation than the one advanced by M. Hatzopoulos (see EBGR 1993/94, 110). According to Hatzopoulos, the verb's original form was $\nu \varepsilon \varepsilon u ́ \omega$, 'to be young' (Thessalian $\nu \varepsilon F \varepsilon u ́ \omega>\nu \varepsilon \beta \varepsilon u ́ \omega)$; the terms $\nu \varepsilon u ́ \sigma \alpha \sigma \alpha$ and

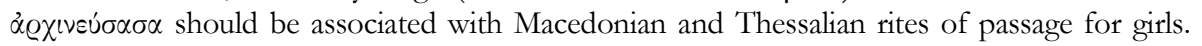
After a brief consideration of the possibility of a running course (cf. Hesychios, s.v. vevevi.

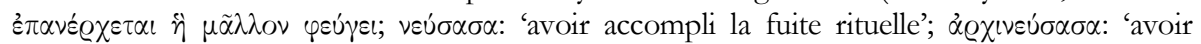
présidé à la fuite rituelle'; p. 152), G. interprets $v \varepsilon u ́ \sigma \alpha \sigma \alpha$ as a reference to the completion of a ritual bath ('having bathed'). A comparison with other terms containing the prefix $\alpha \varrho \chi^{-}$- (court officials, civic magistrates, administrative and military officers, cultic functions, professionals; p. 160f.) demonstrates that the term $\dot{\alpha} \varrho \chi v \varepsilon u ́ \omega$ does not make any sense. Therefore, he suggests

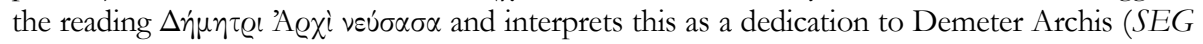


XLIV 535). The terms $v \varepsilon \beta \varepsilon u ́ \sigma \alpha \sigma \alpha$ and ė $\pi \imath \varepsilon \beta \varepsilon u ́ \sigma \alpha \sigma \alpha$ in Thessalian dedications to Artemis Throsia cannot be associated with $\nu \varepsilon F \varepsilon \dot{\omega} \omega>v \varepsilon \beta \varepsilon u ́ \omega$, since the Thessalian inscriptions do not

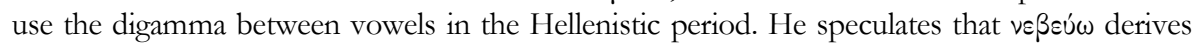

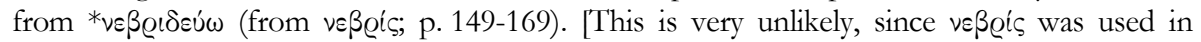
Bacchic rituals, not in Artemis' cult. J.-C. DECOURT - B. HELLY BE 2010, 359, point out that G.'s claim that the digamma was not used in Hellenistic inscriptions of Thessaly is wrong. The digamma appears as a $-\beta$. They regard the derivation of $\nu \varepsilon \beta \varepsilon u ́ \omega$ from $\nu \varepsilon_{f} \sigma \varsigma$ as the most plausible interpretation].

72) C. Grotta, Zeus Meilichios a Selinunte, Rome, 2009: G. presents a detailed study of the archaeological remains and the inscriptions of the area dedicated to the cult of Zeus Meilichios in the sanctuary of Demeter Malophoros in Selinous. He discusses the history of the excavations and the excavation notes, the topography of the sanctuary of Demeter Malophoros, the precinct for the cult of Zeus Meilichios, the inscribed and uninscribed stelae, the deities worshipped in this area and the associated rituals, and the cult of Zeus Meilichios in the Greek world (the epigraphic evidence on p. 279-291). The inscriptions from the precinct of Meilichios are presented in critical editions with detailed commentary (p. 101-136 nos 1-16: IGDS 41-50; ARENA, Iscrizioni greche archaiche di Sicilia e Magna Grecia. I. Iscrizioni di Megara Iblea e Selinunte, Pisa, 19962 , nos 40-51; SEG XXXIV 972). There is an ineditum (6, ca. 50 BCE: [- $\left.\mathrm{M}_{i}[\lambda] i \chi_{\imath} \circ \varepsilon^{2}[\mu i]\right)$ and two fragmentary texts not included in IGDS and Arena (15-16). On pages 190-203, G. examines the lex sacra of Selinous concerning purifications (SEG XLIII 630) [cf. EBGR 1996, 45; 2004, 69 and 74].

73) K. GutZWEILER, “The Demon Mosquito”, ZPE 174 (2010), p. 133-138: A limestone relief from Egypt represents a sleeping naked woman; a second smaller figure, with humanoid features and elongated arms and torso, stands behind her. A short inscription above the

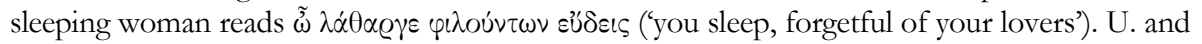
D. HAGEDORN, who published this relief ("Anthologia Palatina V 152 in bildlicher Darstellung?", ZPE 51 [1983], p. 61-64), recognized the text as a quotation of a verse of Meleager's epigram in which the poet asks a mosquito to fly to the sleeping Zenophila and to bring her to him $(A P V, 155)$. G. observes that the relief is paralleled by a group of limestone reliefs from Naukratis (Archaic period) with similar iconography, possibly associated with prostitution. The quote from Meleager seems to have been inscribed in the Imperial period on an object of earlier date. The context may be that of erotic magic, since Meleager's epigram recalls the 'insomnia spell'.

74) H. Hauben, "Rhodes, the League of the Islanders, and the Cult of Ptolemy I Soter", in Philathenaios, p. 103-121: After a thorough examination of the literary and epigraphic evidence, H. accepts as valid the literary tradition, according to which the epiklesis Soter was awarded to Ptolemy I by the Rhodians in 304 BC. The cult of the first Ptolemy was not introduced by the Nesiotic Koinon in ca. 308, but rather much later (288-286 BCE; cf. IG XII.7.506).

75) J. HeINRICHS, “Thrasymacho archontos. Eine bronzene Stierplastik des frühen 5. Jh. v. Chr., phokische Tribole und die delphische Felsinschrift der Labyaden”, ZPE 175 (2010), p. 99-112: A bronze statue of a bull in the antiquities market (Cologne 2010) is inscribed with the name of the archon Thrasymachos. The alphabet and the similarity of the bull with images on Phokian coins suggest that this is a dedication from Delphi (ca. 480 BCE). A Thrasymachos appears in a rock-cut inscription of the phratry of the Labyadai in Delphi.

76) B. HeLly, “Un concurrent originaire d'Antioche de Pisidie dans un catalogue de vainqueurs aux concours des Éleuthéria de Larisa (entre 80 et 70 av. J.-C.)", ZPE 172 (2010), p. 93-99: H. republishes a list of victors at the Eleutheria of Larisa (IG IX.2.529, ca. 80-70). The victors 
were not only men from Thessaly. The victor in the boys' stadion race originated from a city by the name of Antiocheia. His name (Moas) suggests that his city was Antiocheia in Pisidia.

77) B. HeLly, "Consécration d'un enclos funéraire à Ennodia Ilias à Larisa (Thessalie)", Kernos 23 (2010), p. 53-65 [BE 2011, 383]: H.'s starting point is the interpretation of three epithets of

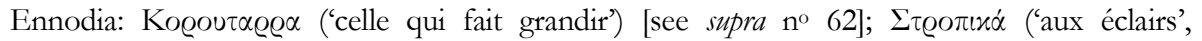

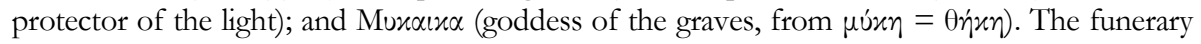
nature of Ennodia may also be inferred from a dedication of a temple to her, Zeus Meilichios, and Poseidon in Larisa (IG IX.2.578). Based on these observations, H. presents a new text of IG IX.2.592 (Larisa, late 2nd cent.). According to his readings and restorations of this text, a person dedicated to Ennodia Ilias (for the epithet cf. SEG LIV 552; EBGR 2005, 35) a

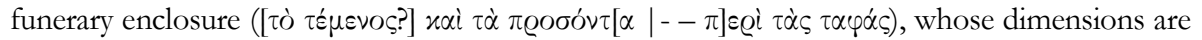
indicated in akainai (cf. SEG XLIII 283); the enclosure may have been used for funerary banquets.

78) P. HERZ, “Überlegungen zur Geschichte des Makedonischen Koinon im 3. Jh. n. Chr.”, in Festrituale in der römischen Kaiserzeit, p. 115-132: H. re-examines the history of the Macedonian Koinon, the imperial cult and its contests, and the neokoriai of Beroia and Thessalonike (see SEG XLIX 815-817; I.Beroia 68/69, 117). H. attributes the name of the contest of the imperial

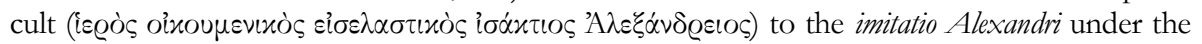
Severans; the date of the agon (late June) corresponds to the adoption of Severus Alexander by Elagabalus (27 June $221 \mathrm{CE}$ ). The festival must have been interrupted between the murder of Severus Alexander $(235 \mathrm{CE}$ ) and his divinization in $238 \mathrm{CE}$. Giving the provincial agon of

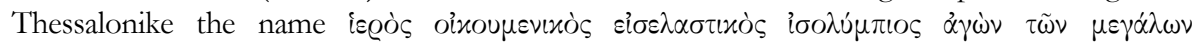

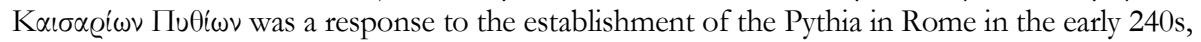

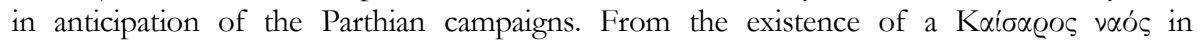

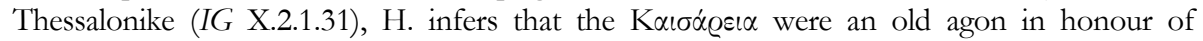
Augustus, which was promoted to sacred status in the mid-3rd cent. CE, possibly in connection with the award of a neokoria to Thessalonike, and associated with the Pythia. The date of the venatio during this festival (20 September) is close to Augustus' birthday (23 September). The $\mu \nu \eta \dot{\mu} \sum \Sigma \varepsilon \beta \alpha \sigma \tau \tilde{\omega} \nu$ that was celebrated during this contest (SEG XLIX 817 1. 9) must, therefore, be a commemoration of Augustus and possibly of other early emperors, as well. The name 'E $\pi \imath v i$ ix $\alpha$ K $\alpha \beta$ si@ $\iota$ was added in 260 CE, possibly after a Roman victory in a naval battle. H. also discusses the high priesthoods of Menon (SEG XLIX 815-816). In 252 CE Menon exercised this office in Beroia, and in 259 and $260 \mathrm{CE}$ in Thessalonike; the

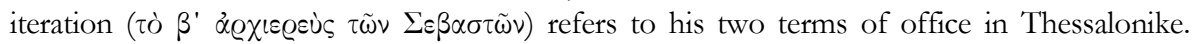
Menon's offer to serve as $\dot{\alpha} \gamma \omega v o \theta$ étns $\delta i \dot{\alpha} \beta i o u$ was probably a response to financial problems in this period. H. collects the evidence for the athletic program of the contests of the Macedonian Koinon (IAG 69, 84, 88; boxing, pankration).

79) G. Hirsch (München), Auktion 254 (13.2.2008), Munich, 2008: The objects offered for sale include two votive reliefs of unknown provenance dedicated to Zeus Orkamaneites as a euche (nos. 68f.; ca. 2nd/3rd cent.) [probably from the vicinity of Banaz in Phrygia, where the sanctuary of Zeus Orkamaneites is located; W. Günther sent us photos and transcriptions].

80) S. Hornblower, "Did the Delphic Amphiktiony Play a Political Role in the Classical Period?", in Greek and Roman Networks, p. $39-56$ [also published in MHR 22 (2007), p. 39-56]: H. gives an overview of the political significance of the Delphic Amphiktyony in the 5th and 4th cent., focusing on the condemnation of the Spartans before the Third Sacred War, the censure of Astykrates and his associates by the Amphiktyony (IG II ${ }^{2} 109,363 \mathrm{BCE}$ ), which $\mathrm{H}$. attributes to political motives (cf. CID II 31 line 34, CID II 67-72), and the outbreak of the Third Sacred War. 
81) S.C. HumphreYs, "A Paranoiac Sycophant? The Curse Tablet NM 14470 (D.R. Jordan and J. Curbera, "ZPE" 166, 2008, 135-150)", ZPE 172 (2010), p. 85-86: H. discusses a recently republished Athenian curse tablet, which is directed against at least 96 individuals (see EBGR 2008, 82; Athens, 4th cent.). The appearance of fathers and sons in the list makes it unlikely that the curse's background was a dispute in a private society (betaireia). The format of the text implies that the author had afterthoughts while he was writing. He first wrote lines 190 on side $A$, and added lines $91 \mathrm{f}$. later. On side $\mathrm{B}$, he wrote additional names on the part of the tablet that he intended to conceal by folding (B columns III-IV); then he added four names (B col. I 93-96), and repeated on B col. I the names of targets about whom he felt especially vindictive. Finally, he folded the tablet twice, pierced it with a nail, and deposited it, possibly in the sanctuary of Zeus Meilichios. The prosopography suggests a milieu of sycophants and men who resorted readily to litigation. Such men had an interest in picking up gossip from prostitutes (present in the list); those targets who were involved in the grain trade could have been involved in shady practices.

82) A. Hupfloher, "Mantische Spezialisten im Osten des Römerreiches", in Religion des Imperium Romanum, p. 273-297: H. gives a useful overview of specialists of divination in the

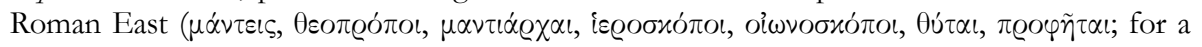

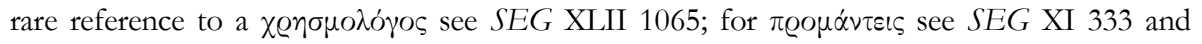
I.Milet II.546). More manteis are epigraphically attested in the post-Classical period than in earlier periods, especially in Olympia (IVO 59-141). H. examines the main places in which cult personnel responsible for divination are attested. In Olympia, ca. 40 manteis, who belonged to the two families of the Iamidai and the Klytiadai, are attested in the Imperial period. Until ca. $185 \mathrm{CE}$, each family appointed one mantis. Later this number was doubled (I $\mathrm{O}$ 59-141; Paus. $\mathrm{V}, 13,11 ; \mathrm{V}, 15,10)$. The manteis probably held their office for lifetime, which consisted of the examination of the intestines of sacrificial animals. They were assisted in the performance of

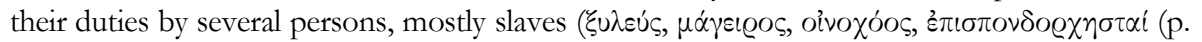
276-279). In Sparta (IG V.1.60, 141, 177, 209-212, 246, 259, 465, 488), the manteis came from a branch of the Iamidai family and from the family of Krios, Megatas, and Skopelos. There is an

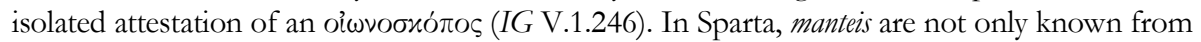
lists of magistrates and participants in banquets but also from honorary inscriptions (IG V.1.259, 488, 578; 279/280). In Thyrrheion in Akarnania, the manteis attended public sacrifices (IG IX.1.247-251); this function was not the exclusive prerogative of a particular family (cf. sacrificial boards in other cities: IG XIV 617/618 + SEG XXIX 988 and XL 855; IG IV 774; I.Magnesia 191; 280/281). Athenian manteis assisted the strategoi (IG II ${ }^{2}$ 17o8; cf. I.Délos 2605) and participated in theoriai to Delphi (F.Delphes III.2.13, 59-65; 282/283). In Hellenistic Boiotia, the Boiotian Koinon regularly requested oracles of Apollo and dedicated tripods in the sanctuaries of Zeus Eleutherios in Plataia, the Charites in Orchomenos, the Muses on Helikon, and Apollo Ptoios in Akraiphia. Manteis and theopropoi participated in this procedure (IG VII 1672/1673, 1795, 2723-2724a, 3207). The theopropos probably received the oracle, whereas the mantis interpreted signs during the sacrifice (284-286). The Roman colony of Corinth mixed Roman and Greek practices, as can be inferred from the designations augur and theocolus. The

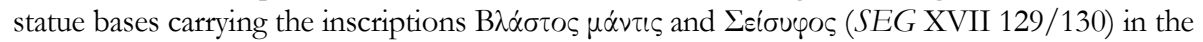
sanctuary at Isthmia probably supported statues of mythical figures. Sisyphos was the founder of the Isthmian games, whereas Blastos lacks a patronymic (286-288) [this interpretation can be supported by the fact that $\mathrm{B} \lambda \dot{\alpha} \sigma \tau \alpha$ was the name of the legendary diviner Epimenides; see Plut., Solon 12, 7; Suda, s.v. B $\lambda \dot{\alpha} \sigma \tau \alpha$ ]. The mantiarches in Ephesos and Cyprus (I.Ephesos 1044; SEG XXX 1608) presents a puzzle, as the name seems to designate the chairman of a board; however, manteis are not attested. It is possible that in Ephesos the mantiarches supervised a board of bieroskopoi (cf. I.Ephesos 1044 line 20). The evidence from Cyprus exists already in the 
Archaic period (SEG XX 162); the mantiarchai are mostly known from dedications and honorific inscriptions (SEG XX 209/210; XXIII 621; XXX 1608). Generally, in the Roman East, the diviners that are known from honorific inscriptions and dedications represent the higher social strata, but the majority of these functionaries belonged to the lower middle class. They mostly served in civic sacrifices.

83) M. ICKS, "Empire of the Sun? Civic Responses to the Rise and Fall of Sol Elagabal in the Roman Empire", in Ritual Dynamics, p. 111-119: Examining the evidence for the cult of Sol Elagabal in Rome and the provinces, I. argues that this cult had little impact outside of the capital and was not intentionally used by the emperor as a means of unifying the empire. It was adopted by cities that were rewarded by the emperor, but this did not lead to great enthusiasm for the new cult, which declined after Elagabal's fall [on the cult see also supra no 30].

84) T. Ismaeldi, "Il monopteros del Santuario di Apollo a Hierapolis di Frigia. Ricerche sull'oracolo alfabetico", MDAI(I) 59 (2009), p. 13-192: I. identifies a monopteros temple (ca. $50 \mathrm{CE}$ ) in the sanctuary of Apollo in Hierapolis as the place where divination by means of an alphabetic oracle was practiced. This practice is attested through an inscription with an alphabetic oracle mentioning Apollo Kareios (J. NOLLÉ, Kleinasiatische Losorakel. Astragal- und Alphabetchresmologien der hochkaiserzeitlichen Orakelrenaissance, Munich, 2007, p. 253-263). This identification is based on a comparison between the architecture of this building and that of sanctuaries in Latium used for the drawing of lots.

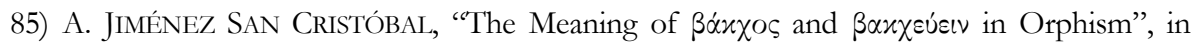
Mystic Cults in Magna Graecia, p. 46-60: After analysing the use of the terms $\beta \dot{\alpha} x \chi 0 \varsigma$ and

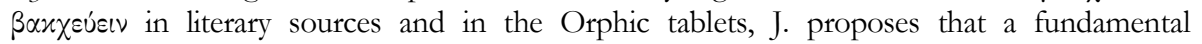
distinction be drawn between those who performed Orphic (and other mystic) rituals ( $\mu$ $\sigma \tau \tau \alpha)$ and those who internalized the values of the Dionysiac-Orphic cult and lived a life in accordance with the Orphic precepts, thereby posthumously reaching a permanent state of holiness in union with Dionysos ( $\beta \dot{\alpha} x \chi \circ, \beta \varepsilon \beta \alpha x \chi \varepsilon \cup \mu \varepsilon$ é $)$. This difference is expressed by the

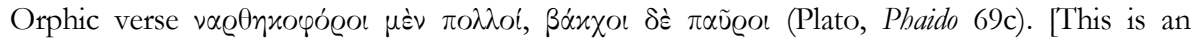
important observation which corresponds to a general trend, from the 6th cent. onwards, away from the automatism of ritual (purification, supplication, initiation, cursing) and towards an internalization of religious values; see A. CHANIOTIS, "Greek Ritual Purity: from Automatisms to Moral Distinctions", in P. RÖSCH - U. SIMON (eds.), How Purity is Made, Weisbaden, 2012, p. 133-135].

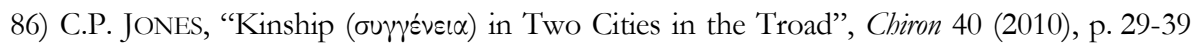

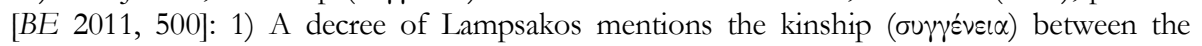
Lampsakenes and the Romans (I.Lampsakos 4, 196 BCE). This mythical kinship may derive from a legend that made Laomedon, the mythical king of Troy, the founder of Lampsakos; one of the city's earlier names was Lamedonteia. Traditions referring to superimposed layers of settlement, such as the ones that made Lampsakos an Aiolian settlement, a foundation by

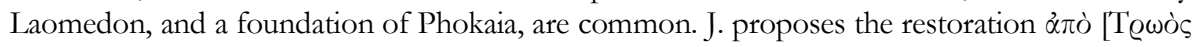
[ $x \alpha \tau \dot{\alpha} \gamma о \mu \varepsilon v]$ in the passage that explains the claim of kinship between Lampsakos and Rome. 2) An inscription from Larisa refers to the kinship between Larisa and Alexandreia/Troas (SEG LVI 638, ca. 160-150). This kinship is not associated with a ritual pilgrimage dispatched from Larisa to the tomb of Achilles (as suspected by B. Helly), since this pilgrimage went to Ilion, not to Alexandreia. The kinship was based on the Aiolian ancestry of Alexandreia and of the cities that it had annexed (Neandria and Larisa of the Troad); the old name of Thessaly was Aiolis 
87) M. KajAVA, "Osservazioni sulle dediche sacre nei contesti oracolari”, in Dediche sacre, p. 209-225: Adducing a large number of Greek and Latin inscriptions, K. discusses the general features of dedications made after the consultation of an oracle or in accordance with an oracle

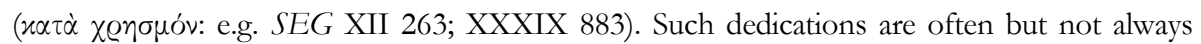
found in oracular sanctuaries and name the deity that gave the oracle (e.g. IG XII.5.913; IGR IV 1498; IGBulg I2 370). In one instance, reference is made to an ancient oracle (I.Magnesia 215). Dedications made in accordance with the interpretation of an oracle of Apollo Klarios

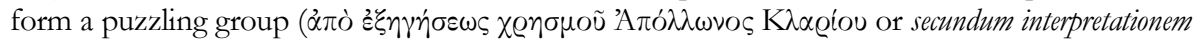
oraculi Clarii Apollinis; see SEG LIII 1587; cf. M. KAJAVA, 'Ex oraculo', in A. LEONE et al. (eds.), Res bene gestae. Ricerche di storia urbana su Roma antica in onore di Eva Margareta Steinby, Rome, 2007,

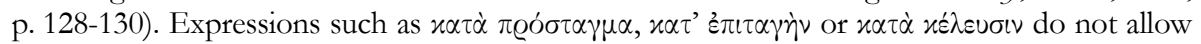
us to determine the means of communication between a mortal and a god (oracle, other form of divination, dream); from the Hellenistic period on, the expression $x \alpha \tau \dot{\alpha} \chi \varrho \eta \sigma \mu o ̀ v / x \alpha \tau \dot{\alpha}$ $\chi \varrho \eta \mu \alpha \tau \iota \mu$ óv may also refer to dreams and visions. An interesting group consists of oracles with which a god recommends a dedication to another god (e.g. IG VII 3098; I.Philae 168).

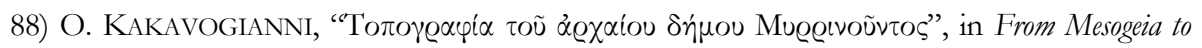
Argosaronikos, p. 47-78: K. summarizes the topography of the deme of Myrrhinous in Attica, discussing also the remains of cult places. A temple in the most important sanctuary of the deme may be that of Artemis Kolainis (p. 62; cf. O. KAKAVOGIANNI - V. ArgYropoulos,

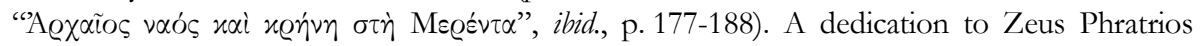
permits the identification of a shrine near the sanctuary as belonging to this god (and to Athena Phratria?, p. 64) [see EBGR 2008, 83 and the remarks of C. FEYEL, BE 2010, 220]. A cult place at some distance from the temple may be the temenos of Apollo Pythios mentioned in a dedication (p. 67; M. Mitsos - E. VANDERPOOL, "Inscriptions from Attica", Hesperia 19 [1950], p. 25f. no 1). In a sanctuary of Aphrodite, objects inscribed with the names of women were found (a loomweight and a plaque). K. suspects that they were prostitutes, sacred slaves of the sanctuary (p. 69; cf. infra no 89) [but see the objections of C. FEYEL, BE 2010, 220].

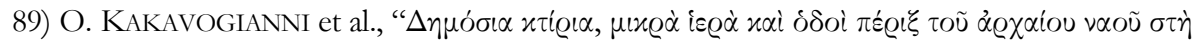

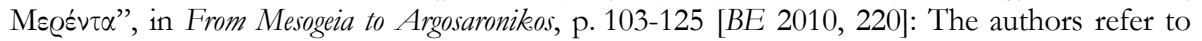
archaeological and epigraphic evidence for sanctuaries in the area of the Attic deme of Myrrinous [see supra $\mathrm{n}^{\circ}$ 88]: the temenos of Apollo Pythios (p. 112f.), the sanctuary of Aphrodite (p. 114-117), and the shrine of Zeus Phratrios (p. 116-123).

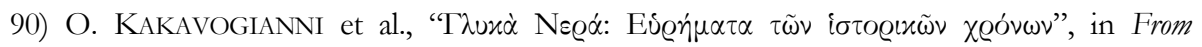
Mesogeia to Argosaronikos, p. 423-432 [BE 2010, 222]: The authors mention a boundary stone of a road leading to the A A 222, tentatively suggests that the Halieion was a sanctuary of Nymphe Halia, whose cult is known in Oropos.

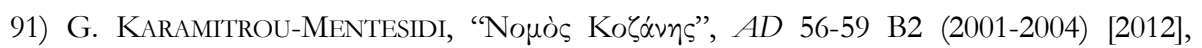
p. 392-393: The right part of a votive relief stele with a representation of Enodia was found at Pontokomi Kozanis (Imperial period). The goddess holds torches in her raised hands; remains of two animals (a horse and a dog) are visible. The dedicatory inscription is not well preserved, but the verb $[\dot{\alpha} v \varepsilon \dot{\varepsilon}] \theta \eta \chi \varepsilon[v]$ can be recognized.

92) K. KARILA-COHEN, "Les filles d'Athènes à Delphes : femmes, religion et société à travers l'exemple des canéphores de la Pythaïde", in Chemin faisant, p. 133-142 [BE 2011, 213]: K.-C. discusses the participation of kanephoroi in the Hellenistic Pythaids, i.e. the processions dispatched by Athens to honour Apollo Pythios at irregular intervals in 138/7, 127/7, 106/5, and 98/97 BCE [cf. EBGR 2005, 76 and 90; 2008, 86]. On the basis of the preserved evidence 
(F.Delphes III.2.29-31; cf. IG II ${ }^{2}$ 3477; I.Délos 2336; SEG XXXIII 197), she compiles a prosopography of the known kanephoroi and discusses their social position. They belonged to the most important elite families, known for their wealth and public activities. Unlike the more numerous male participants, no kanephoroi are known to have attended more than one Pythaid, probably because they married before the occasion of the next Pythaid. In the procession, the group of the kanephoroi was probably associated with that of the paides.

93) K. KARILA-COHEN, "L'étude du sentiment religieux à partir du lexique : l'exemple de

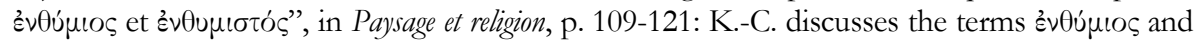

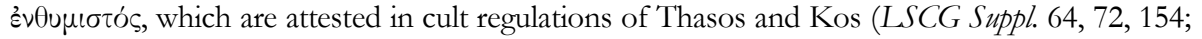
SEG LIV 743; SEGRE, Iscr.Cos ED 122), in a funerary imprecation from Kos (PH 319), and in a prayer for justice (I.Knidos $150 \mathrm{~B}$ ), as well as in a few literary sources. [One should add to her catalogue two recent epigraphic attestations (both cult regulations, again, from Thasos and Kos): SEG LV 930 and SEG LVI 1017; cf. EBGR 2006, 54]. These words always appear in the context of transgressions committed by humans and subject to divine punishment: 'Il s'agit d'un sentiment de danger impliquant l'action d'une puissance supérieure'.

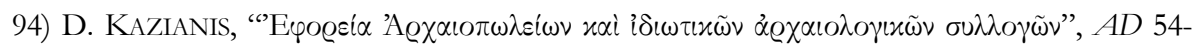
56 B6 (2001-2004) [2012], p. 599-608: K. mentions a votive relief of unknown provenance in a private collection (4th cent.). The relief, dedicated by a priest, shows a banquet scene with a reclined man, a seated woman, a naked slave, and a group of four worshippers; a horse protome is on the left upper corner (p. 602).

95) S. KERNEIS, "La question enchantée. Les jugements des dieux dans l'île de Bretagne (IIe-IVe siècle)”, RHDFRE 88 (2010), p. 449-498: K. discusses the legal aspects of prayers of justice from Britain (Bath), especially those that concern theft. She argues convincingly that these texts reflect a procedure consisting of two phases. In a first phase the complaint and a threat of punishment are formulated. The authors of the texts employ a vocabulary that derives from Roman law (e.g., reus, petitio, commonitorium), invoking the maiestas of the god and requesting their intervention in the discovery and return of the stolen object (invenire, exigere, exactura). The god is assimilated to a judge (in suum rostrum). Some texts stipulate a deadline of nine days (cf. the nundinae). The god is asked to intervene only if a reconciliation between the victim and the culprit is not achieved. These two procedural steps resemble the Roman actions of delatio and receptio nominis. $\mathrm{K}$. assumes that such accusations were displayed in the temple at Aquae Sulis in imitation of the album in Rome. In this phase, which aimed at conflict resolution, the involvement of priests was essential. In a second phase, when reconciliation was not achieved, either because the suspect denied the accusation or because there was no suspect, the victim requested the vengeance of supernatural powers. The god is expected to investigate the case and to punish the thief (cf. cognitio). Some form of incubation and divinatory dreams, possibly also an ordeal, may be associated with this phase. If the thief was not revealed, then a proper cursing took place. These texts are evidence of acculturation and the influence of Roman law. [The great similarity to procedures that can be reconstructed with the help of prayers for justice and 'confession inscriptions' from the Roman East (see more recently EBGR 2009, 33, with further bibliography; see also infra $n^{\circ} 199$ ) suggest that there was also some transfer of practices from the East].

96) D. KNOEPFLER, La patrie de Narcisse. Un héros mythique enraciné dans le sol et dans l'bistoire d'une cité grecque, Paris, 2010 [BE 2011, 331]: In this impressive study of the myth, cult, and reception of Narkissos and his association with different regions (especially Euboia and Boiotia), K. adduces several inscriptions, especially the metrical dedication of Hadrian in Thespiai (IG VII 1828; p. 62-65) [cf. EBGR 2004, 102], and inscriptions attesting the existence of an Eretrian tribe named after Narkissos (Narkittis, p. 101-126). In an appendix, K. publishes two new 
choregic monuments from Eretria that mention the tribe Narkittis and republished three further choregic monuments (IG XII.9.273-275, 4th cent.): the victorious choregoi of boy choruses dedicated tripods to Dionysos.

97) D. KNOEPfler, "Débris d'évergésie au gymnase d'Éretrie”, in O. CURTY (ed.), L'buile et l'argent. Gymnasiarchie et évergétisme dans la Grèce hellénistique. Actes du colloque tenu à Fribourg du 13 au 15 octobre 2005, publiés en l'bonneur du Prof. Marcel Piérart à l'occasion de son 60 anniversaire, Paris, 2009, p. 203-257: K. examines fragmentary inscriptions from the Hellenistic gymnasion of Eretria. Small fragments belong to a dedicatory inscription that records the dedication of a basin by Kalliteles and his son to Hermes and Herakles (p. 213-219). Two other fragments belong to a dedication made by the gymnasiarch Elpinikos to Hermes (p. 223-234). A small fragment with the letters KETAH $\Sigma$ may belong to an inscription that recorded the dedication of one or more stelai bearing the epic poems of Hesiod (or parts thereof): e.g. [ $\alpha \dot{\varepsilon} \theta \eta\rceil] \varkappa \varepsilon \dot{\alpha}$ 'H $\sigma[\iota \dot{\delta} \delta 0 \mathrm{v}$ ér $\eta]$. Alternative restorations are not excluded (219-223).

98) O. KÖSE - R. TeKOĞLU, "Money Lending in Hellenistic Lycia. The Union of Copper Money", Adalya 10 (2007), p. 63-76: Ed. pr. of an inscription concerning a foundation [for its content see infra $\left.\mathrm{n}^{\circ} 143\right]$.

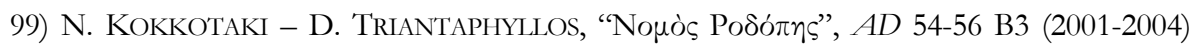
[2012], p. 756-757 [SEG LIX 683]: Ed. pr. of a thanksgiving dedication inscribed on a small

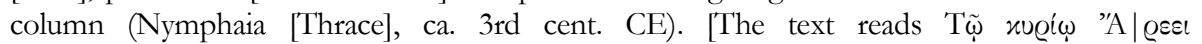

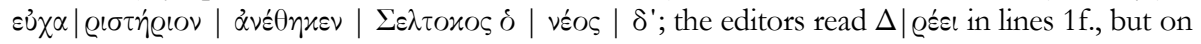

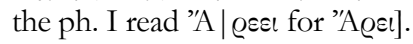

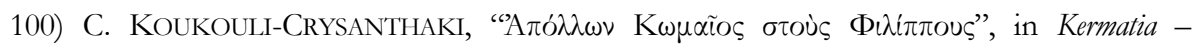
Touratsoglou II, p. 481-503 [BE 2011, 427; SEG LIX 691]: Ed. pr. of a dedication to Apollo Komaios and Artemis from Philippi (ca. 350-300). A similar dedication (Philippi $\mathrm{II}^{2} 246$ ) was found in situ at the corner of two streets, east of the market. Apollo's epithet probably derives from $x \omega \dot{\mu} \mu$ rather than $x \omega \mu$ 's, and characterizes the god as patron of villages (cf. 'A $\dot{0} \dot{\lambda} \lambda \lambda \omega \nu$

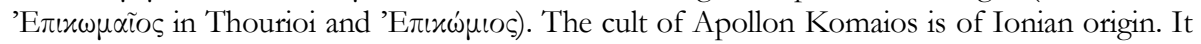
is attested in Naukratis (Athenaios IV 49d) and Thasos (SEG XVII 415; LSCG Suppl. 69:

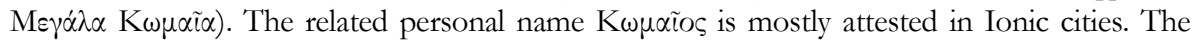
cult was brought from Paros to Thasos and thence to the Thasian Peraia and Philippi. Macedonian colonists brought it to Seleukeia in Syria, whence the god's statue was transported to the Palatine Hill in Rome.

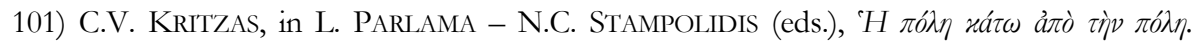

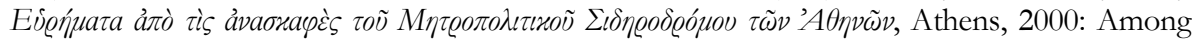
the finds made during the construction of the Athenian Metro and exhibited at the Goulandris Museum (2000-01) were several inscriptions presented by K. The texts include a fragmentary account of the Athenian amphiktyones of the Delian amphiktyony (123, ca.345-3 BCE); a bronze torch dedicated by the winner of the torch race; the dedicant was the leader of a team of pareutaktoi, i.e. young men in the final stage of ephebeia (174, 1st cent.); and the epitaph of a priestess of Isis (179, ca. $150 \mathrm{CE}$ ) [see now P. MARTZAVOU, "Priests and Priestly Roles in the Isiac Cults", in A. CHANIOTIS (ed.), Ritual Dynamics in the Ancient Mediterranean: Agency, Emotion, Gender, Representation, Stuttgart, 2011, p. 69f. note 58].

102) C. KRITZAS, "E

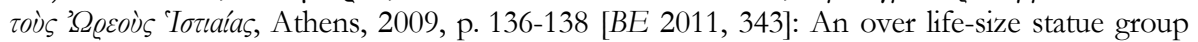
representing Herakles fighting against the Nemean lion was found in 1992 in the area of a sanctuary in Oreioi (Euboia, ca. 600-550). As the excavator, E. SAPOUNA-SAKELLARAKI, assumes, the sanctuary was probably dedicated to the worship of Herakles, who is often 
associated with springs and healing waters (p. 67-71). K. presents the ed.pr. of the dedicatory

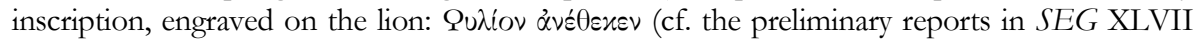
1369; XLIX 1203; LIII 930; EBGR 1997, 11).

103) A.J.M. Kropp, "Jupiter, Venus, and Mercury of Heliopolis (Baalbek). The Images of the 'Triad' and its Alleged Syncretisms", Syria 87 (2010), p. 229-264: After detailed study of the epigraphic and iconographic material concerning the existence of a triad of gods in Heliopolis, consisting of Zeus/Jupiter/Hadad, Aphrodite/Venus/Atargatis/Dea Syria, and Hermes/ Mercurius, $\mathrm{K}$. argues that this triad never existed. Zeus/Jupiter Heliopolitanus is a late creation of the Roman period. The identification of Aphrodite/Venus with Atargatis is unfounded. Hermes/Mercury and his imagery should be separated from that of Dionysos. Radiant divinities should be regarded as separate Helios figures, not to be associated with either Zeus/ Jupiter or Hermes/Mercury.

104) G. LABARRE, "Les origines et la diffusion du culte de Men”, in H. BRU - F. KIRBIHLER S. LEBRETON (eds.), L'Asie Mineure dans l'Antiquité : échanges, populations et territoires. Regards actuels sur une péninsule (Actes du colloque international de Tours, 21-22 octobre 2005), Rennes, 2009, p. 389414: L. explores the origins and the develpoment of the cult of Mes. The pre-Hellenistic origins of the cult are unclear. In the Imperial period, the iconographic and inscriptional evidence show a combination of Greek and indigenous elements, the latter being visible in the power of sanctuaries, in local cultic traditions (the ritual of tekomerenein in Antiocheia) [cf. supra no 14], and in local epithets. The cult experienced a significant diffusion, first due to the mobility of slaves and merchants, and later due to progressive urbanisation. L. adduces some confession inscriptions and dedications.

105) G. LABARRE - M. ÖSZAIT, "Une salle de banquet pour Men et les Volumnii d'Antioche de Pisidie”, DHA 33.2 (2007), p. 91-114 [SEG LVII 1398]: L.-Ö. republish an inscribed sacrificial table from Antiocheia in Pisidia, dedicated to Men by a certain Protion (CMRDM

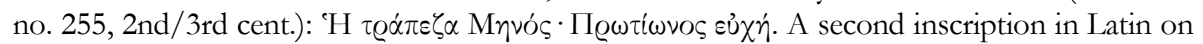
a side of the table, discovered by L.-Ö., indicates that Protion was a Roman citizen: $Q$. Volumnius Protio cenaculum l(ibens) v(otum) s(olvit). This man, also known from a dedicatory epigram as the dedicant of an altar to Mes (MERKELBACH-STAUBER, SGO III 404 $\mathrm{n}^{\circ} 16 / 61 / 02$ ), was probably a freedman or a descendant of a freedman. He did not only dedicate a table for food offerings, a common feature in the cult of Men, but also a banquet hall (cenaculum). The authors argue that the table was erected in the sanctuary of Men on Mount Karakuyin [see also supra no 14]. Several Volumnii are known to have served as tekmores [on this function see EBGR 2004, 159, 166, and 176. The text is now republished by M. CHRISTOL, T. DREW-BEAR, "Une famille de notabilité à Antioche de Pisidie: les Volumnii", LAC 78 (2009), p. 178-180 (ph.), who in line 3 of the Latin text read L(unae) v(otum) solvit. They also study the family of the Volumnii in Antiocheia].

106) C. Lagos, "Athena Itonia at Amorgos. A New Interpretation of the Evidence", in Kermatia - Touratsoglou II, p. 81-89: The cult of Athena Itonia on Amorgos, in Arkesine and Minoa (cf. IG XII.7.22, 24-25, 33, 35-36, 229), was introduced in the Hellenistic period. The combination of Zeus' cult with that of Athena bespeaks a Boiotian (not Thessalian) origin. A likely candidate for the cult's introduction is the nesiarch Bakchon (ca. 288-279), who was a Boiotian (IG XII.4.1125/1126). His superior, the Ptolemaic official Philokles of Sidon, also had contacts in Boiotia. In Boiotia and Thessaly, the cult of Athena Itonia was practiced by the local koina. L. plausibly argues that in Amorgos, too, the cult may have had a supra-local character, possibly as a cult of the Amorgian koinon. 
107) E. LANZA CATTI, "Financial Features, Work Organization, and Building Technologies in Classical Athens", in Philathenaios, p. 33-43: The author examines the Parthenon accounts (IG $\mathrm{I}^{3}$ 436-451, 446-432 BCE) as a source of information for the building projects on the Acropolis (wages, building procedure, purchase of ivory).

108) F. LEFÈVRE, “Autour de la 'stèle des syla”, CRAI (2009), p. 811-841 [BE 2011, 652]: A stele in Kyrene from the late 4th cent. records the outcome of embassies sent by Kyrene to certain cities and sanctuaries in order to offer financial compensation and to evade reprisals (A. LARONDE, Cyrène et la Libye bellénistique, Paris, 1987, p. 149-161; cf. SEG XXVII 1194). L. discusses lines 7-16, which refer to affairs in Greece. The envoys visited three sanctuaries and resolved open issues with the bellanodikai in the sanctuary of Zeus in Olympia, the amphiktyones in Delphi, and the bieromnemones in the sanctuary of Zeus Lykaios on Mt. Lykaion in Arkadia. The visit in Olympia and Delphi may be explained by the prominence of these sanctuaries as places for public announcements and deposition of documents. Also the sanctuary of Zeus Lykaios may have been the center of a local amphiktyony. The debts that risked Kyrene becoming the victim of reprisals may originate in obligations connected with contests. With regard to the significance of Delphi in international arbitration, L. adduces documents concerning the repayment of money owed by Drymaia to a sanctuary and to the Oitaioi (IG IX.1.226-230, ca. 160). According to A. Giovannini (EBGR 2004, 94), the Delphic amphiktyony was involved in this affair because the sanctuary of Apollo (not the federal sanctuary of the Oitaioi) was one of the creditors. L. rejects this interpretation, observing that the formulation

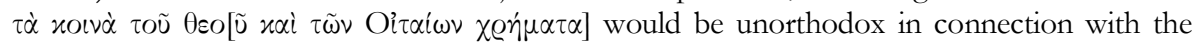
Delphic Apollo. There is no evidence that in this period the Delphic sanctuary functioned as a

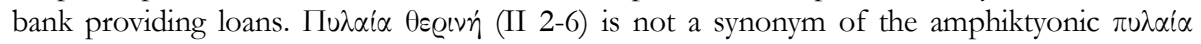

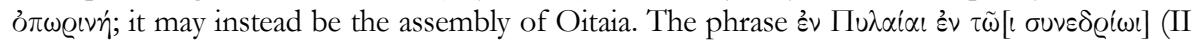
27f.) should be understood in a topographical sense: 'aux Pyles, dans la salle du conseil'. The conflicting parties used the seat of the amphiktyonic council to resolve the conflict, perhaps during a regular meeting of the amphiktyony and in the presence of the bieromnemones. Delphi was involved in this affair not as a creditor but as a higher moral authority and possibly as the place where the receipt of the final payment of the debt was deposited. An incident narrated by Quintilian (Inst. V, 10, 110-118) may be relevant. When Alexander the Great discovered in Thebes tablets recording a loan that the Thebans had given to the Thessalians, he cancelled the debt. When Kassandros re-founded Thebes, the Thebans brought this case before the amphiktyony. While the historicity of this incident is doubtful, Quintilian's account may nevertheless reflect the fact that the amphiktyony arbitrated in such cases.

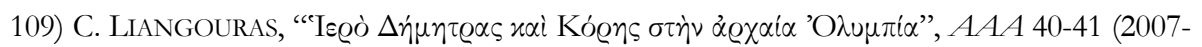
08) [2009], p. 61-74 [BE 2010, 256]: L. reports on the discovery of a small shrine of Demeter and Kore to the east of the stadium of Olympia (p. 70f.). One of the finds is an inscribed clay sphinx or griffon dedicated to Demeter, Kore, and Basileus (i.e., Plouton). This sanctuary may be that of Demeter Chamyne (cf. Pausanias VI, 21.1-2).

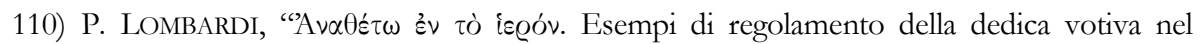
mondo greco", in Dediche sacre, p. 95-126: In this important contribution to the study of Greek sanctuaries, L. collects and discusses inscriptions regulating the dedicatory practices and the management of dedications in sanctuaries (ownership, protection, removal, permission to set up dedications, placement, maintenance, replacement, obligatory dedications, etc.). She discusses the following regulations: $L S A M 11,59,62,72,74,159 ;$; LCG 5, 41, 42, 50, 65, 68, 70, 112; LSCG Suppl. 43, 45 lines 33-38; 72, 107, 111, 123; IG XII.3.170; SEG LV 931; I.Priene 113 col. XXX 91-97; IGLS 1261 + SEG LV 1641 [cf. EBGR 2005, 148]; cf. Herodotos 1.144.10; Plato, Laws 955e; Aischines, Against Ktesiphon 21; Paus. 2.33. 
111) J. MA, “The Inventory SEG XXVI 139, and the Athenian Asklepieion”, Tekmeria 9 (2008) 7-16 [SEG LVIII 157]: M. republishes two fragmentary inscriptions from the Athenian Agora (SEG XXVI 139, ca. 170-135) with numerous new restorations. He challenges the traditional interpretation, according to which the two fragments belong together and are parts of the

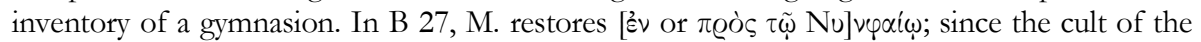
Nymphs was spatially connected with that of Asklepios (cf. IG II ${ }^{2}$ 4994), this fragment may belong to an inventory of the Asklepieion. The text also refers to dining halls (lines 45 and 50:

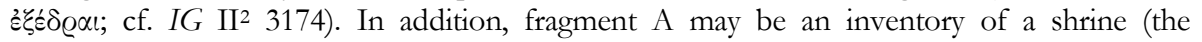

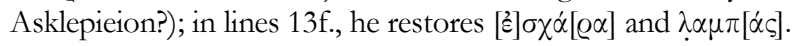

112) S. MÄGELE - J. RiCHARD - M. WAELKENS, “A Late Hadrianic Nymphaeum at Sagalassos (Pisidia, Turkey): A Preliminary Report”, MDAI(I) 57 (2007), p. 490-492 [SEG LVII 1410]: Ed. pr. of a dedication to Hadrian discovered in a Nymphaion at Sagalassos (p. 490f.).

113) S. MAILlot, "Une association de sculpteurs à Rhodes au 2e siècle avant J.-C.", in Chemin faisant, p. 39-57 [BE 2011, 468]: An inscription from Rhodes contains a list of victors in the contests of a private association and a list of benefactors (IG XII.1.127; I.Selge T 54, ca. 200150). This xoเvòv 'A $\sigma x \lambda \alpha \pi \iota \alpha \sigma \tau \tilde{\alpha} \nu$ N $\mathrm{N} \varkappa \alpha \sigma \iota \omega v \varepsilon i \omega \nu$ 'O $\lambda u \mu \pi \iota \alpha \sigma \tau \tilde{\alpha} \nu$, founded by Nikasion, was

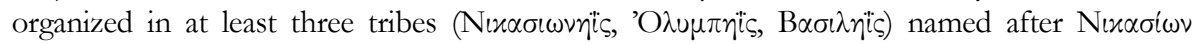

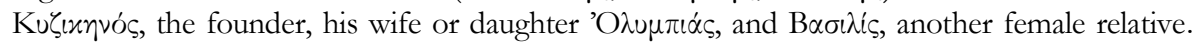
The koinon was dedicated to the cult of Asklepios. As regards the name 'O $\lambda u \mu \pi \iota \sigma \tau \alpha i$, M. prefers to associate it with Olympias rather than with a festival 'O $\lambda \dot{\mu} \mu \pi \iota$. [In that case, the koinon was dedicated to a (heroic) cult of Olympias. But did Olympias alone receive a cult, and not the other individuals after whom the tribes were named (Nikasion and Basilis)? In the

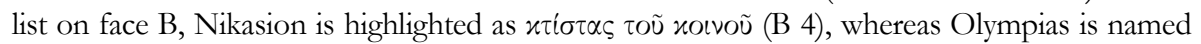

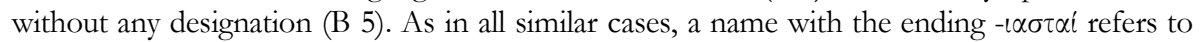

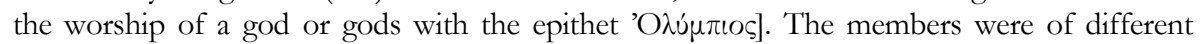
origins and, as M.'s study reveals, they were sculptors.

114) A.K. MAKRES, “A New Ephebic Dedication from Athens and Agora I 5738 and 6577 Revisited”, in Philathenaios, p. 179-195 [BE 2011, 216]: Ed. pr. of a dedicatory inscription that records a victory in a torch race (Athens, 1st cent. BCE/CE). M. also republishes two further dedications of torches by victorious ephebes under the same paidotribes (SEG XXI 685/686). One of the two bases was reused for a dedication to Hadrian.

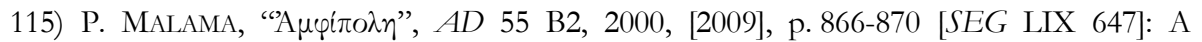
kantharos found near a Hellenistic grave in the east cemetery of Amphipolis (Hellenistic?) is inscribed with the text $\Delta ı \iota_{\varsigma} \sum \omega \tau \tilde{\eta} \varrho o \varsigma$ [the kantharos was used for libations to Zeus Soter; cf. EBGR 2007, 6].

116) G. Manganaro, "Il paesaggio agrario di Halaesa Archonidea", Epigrafica 71 (2009), p. 10-28: M. briefly discusses the decree of the koinon of the priests of Apollo from Halaisa in honor of a benefactor (p. 21-28) [see infra no 177]. According to his view, the koinon of the priests was an association of all the priests of all the cults of the city; the number of 825 votes cast in favor of the decree refers to the citizens and not to the priests alone. [Both assumptions are wrong. First, the koinon is explicitly called 'koinon of the priests of Apollo', not 'of the priests' in general; priests of other cults were certainly not members of the koinon. Second, the text explicitly states that it was a decision of the assembly ( balia) of the priests. There is no way to get around the fact that the text implies that there were 825 priests (or 'priests') of Apollo. Since we cannot assume that they were former priests, the only explanation that I can give is that at that moment the members of the halia - that is, the citizens - designated themselves as 'priests of Apollo', possibly because they had dedicated their city and territory to Apollo, just as 
the Teians did in the late 3rd cent., when they dedicated their city and its territory to Dionysos].

117) G. Manganaro Perrone, "Magia 'benefica' nella Sicilia tardoantica", Epigraphica 69 (2007), p. 263-286 [SEG LVII 862]: M.P. provides an overview of magical practices that aimed to protect human beings, their fields, and their property in Late Antique Sicily. The relevant documents are Christian exorcistic prayers for the protection of vineyards and trees as well as various types of amulets. The texts evince an influence from pagan and Jewish magical practices.

118) A. MANIERI, Agoni poetico-musicali nella Grecia antica. 1. Boeozia, Pisa-Roma, 2009 [BE 2010, 269, 279, 288, 291, 301, 305, 312, 315]: M. offers a systematic study of the music contests held in Boiotian cities. The book includes an introduction to music contests in ancient Greece (p. 17-32) and to music contests in Boiotia (p. 33-58; victors, disciplines). The epigraphic evidence for each agonistic festival is presented in the main part of the book, preceded by a detailed examination of the festival's history and program. The festivals studied comprise the Ptoia and Soteria in Akraiphia, the Basileia and Trophonia in Lebadeia [see EBGR 2009, 81], the

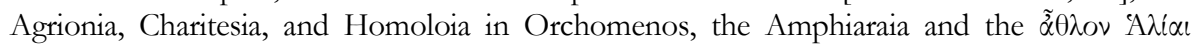
Núryal in Oropos, the Sarapieia in Tanagra, the Agrionia, Rhomaia, and Dionysia Herakleia in Thebes, and the Mouseia and Erotidaia in Thespiai. M. produces critical editions and commentaries of the relevant inscriptions. The inscriptions include decrees for the establishment, organization, and recognition of contests (Acr 1, 4-8, 10-13; Theb 5-6; Thesp 10-15); a senatus consultum (Oro 14); oracles (Acr 2); donations of funds (Acr 3, 9; Thesp 16); agonistic catalogues (Acr 14-16, 18A, 20-24A, 25, 27-28; Leb 9, 11; Orc 23-25; Oro 5, 15-21; Tan 2-4; Theb 8-11, 13; Thesp 17-20, 23-24, 27-31, 33-36, 42-44, 47-49, 53, 57); accounts of agonothetai (Acr 15-16; Leb 11; Tan 2; Thesp 22); letters (Leb 12); honorary inscriptions for individuals for their services (Acr 17, 18B, 19, 24B; Leb 5; Oro 3, 8, 13; Tan 1; Theb 7; Thesp 25-26, 32, 37-41, 45-46, 52, 54, 56); lists of victories (Leb 15-16; Theb 16-17); honorary inscriptions for victors and performers (Leb 4, 6, 10; Oro 6-7, 9-10; Theb 14-15; Thesp 7); dedications by victors (Leb 7, 14; Thesp 8-9, 20-21), agonothetai (Thesp 55), and choregoi (Orc 3-22; Oro 22-30); and other dedications (Acr 26; Orc 2, 27; Oro 11-12). [On victories $\delta i \dot{\alpha}$

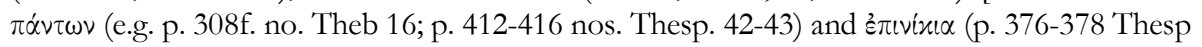
18) see now SEG LVI 2152. I have not systematically reviewed the translations, but I did occasionally notice minor inaccuracies. 'Spettacoli' $(233,267)$ is not an accurate translation for

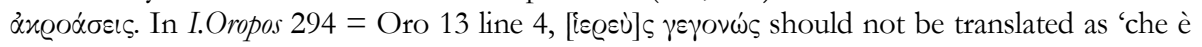
sacerdote' but 'has served [in the past] as priest'. In the case of the famous honorary decree for

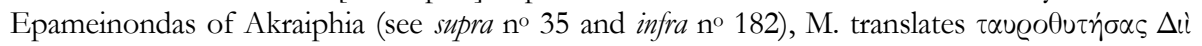

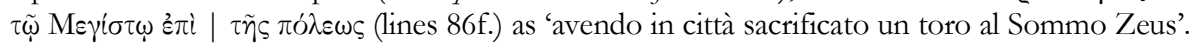

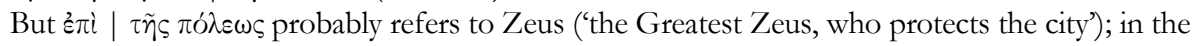

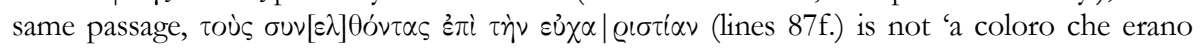
convenuti per il sacrificio di ringranziamento' but 'for those who had come together to thank

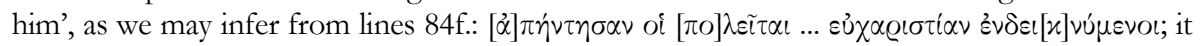

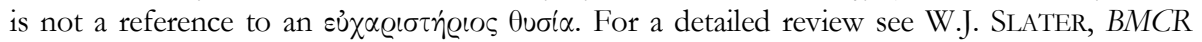
2010.06.09; see also the remarks of D. KNOEPFLER in BE].

119) M. Manoledakis, “A Proposal Relating to a Votive Inscription to Zeus Helios from Pontus”, ZPE 173 (2010), p. 116-118: The epithet of Zeus Helios in a dedication found east of Sinope (D.M. RobINSON, "Greek and Latin Inscriptions from Sinope and Environs", $A J A 9$, 1905 , p. 303f.) is partly preserved. M. suggests the restoration $N \alpha v[\tau \alpha] \mu \eta \nu \tilde{\omega}$. Nautamenos is an epithet deriving from a place name. This place may be Naustathmos, a harbor situated between Sinope and Amisos. In Latin sources this place name appears in the forms Nautagmo, 
Nautacmon, and Nautamno; Naustathmos could have become Nautamos or Nautamon during the Imperial period.

120) G. Marginesu, "Noti sui rendiconti ateniesi di statue del V secolo a.C.", PP 64 (2009), p. 460-474: Analysis of the Athenian accounts referring to the construction, decoration, and placement of the statues of Athena and Hephaistos in the Hephaistion (ca. 421-416; IG I 472 lines 139-160). These accounts were inscribed in order to display Athenian piety.

121) J. M. MARSTON, "Language of Ritual Cursing in the Binding of Prometheus", GRBS 47 (2007), p. 121-133: Through a comparison of the expressions used in binding spells and the description of the binding of Prometheus in Prometheus Bound, M. argues that the Athenian audience of the play, which M. dates to the late 5th cent., would have understood the binding of Prometheus as a magical ritual. On p. 131, he cites a defixio from Aegina [see EBGR 2008, 62 on $\left.I G I^{2} \cdot 2 \cdot 1012\right]$.

122) R. MARTín HernÁndeZ, "A Magical Amulet at the Abbey of Montserat", ZPE 172 (2010), p. 220-222: Ed. pr. of a fragmentary papyrus with a prophylactic spell. The hitherto unattested magical word $\alpha \varrho \chi \alpha \chi \alpha \mu \alpha \varrho \iota \alpha \chi \alpha \beta \varepsilon \lambda$ (cf. $\alpha \chi \varrho \alpha \mu \alpha \chi \alpha \mu \alpha \varrho \iota$ ) is repeated on successive lines, each time dropping its final letter, thereby creating a wing-shaped image.

123) A. Mastrocinque, “Late Antique Lamps with Defixiones”, GRBS 47 (2007), p. 87-99: M. discusses the particular cursing practice of placing lead tablets with curses in lamps and throwing them into the sacred spring of Anna Perenna in Rome. Seven unused lamps contained defixiones - six of them written on lead sheets, and one on a copper tablet (early 4th cent. CE). Cursing rites are also recognizable in the existence of dolls with lead or iron nails piercing their heads; the dolls were placed in lead canisters inscribed with curses. An early and isolated parallel for a similar use of a lamp is offered by an Athenian lamp with a curse written with black paint and placed under the floor of a house (Agora XXI no. C32). M. suspects that the unused lamps thrown into cisterns in Nemea may have been used for magical purposes. The magical papyri (e.g. PMG II 170-174) contain recipes for the use of lamps. He adduces further evidence for the use of cisterns, pits, and wells in magic.

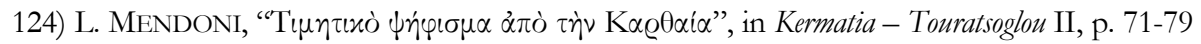
[SEG LIX 930]: Ed. pr. of an honorary decree for Theokles, while he was still serving as a stephanephoros (Karthaia, ca. 300-250). The decree confirms the primarily religious duties of the

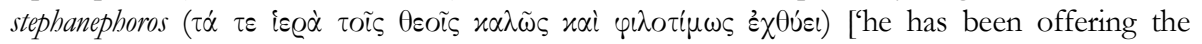

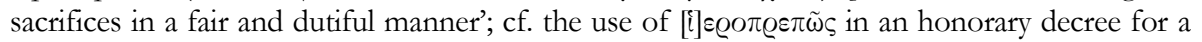

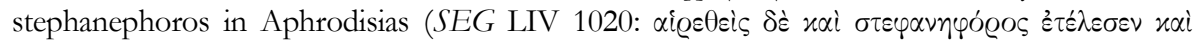

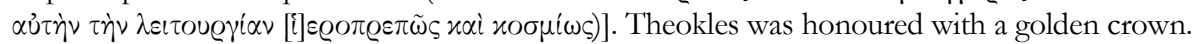
The honours were announced at the Dionysia. He was to receive from the treasurer 15

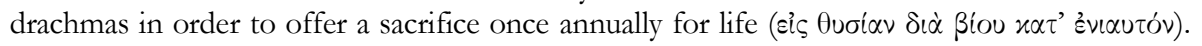
An unusual feature of this honour is that it lasts a lifetime (unlike the one-time grant of money for sacrifices, as in IG VII 4254 lines 34-37; IG XII.7.225 lines 6-8, etc.). The decree was set up in the sanctuary of Apollo.

125) R. MerkelbaCH - J. STAUbER, Steinepigramme aus dem griechischen Osten. Band 5. Register, Munich-Leipzig, 2004: The last volume of the collection of epigrams from the Greek East contains, in addition to corrections and indices, several new texts. I mention an ineditum of religious interest: a grave epigram from Antiocheia in Pisidia (ca. 300 CE, 42f. no. 24/29): [- - -

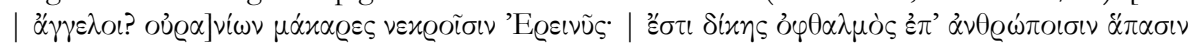

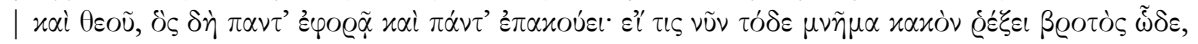

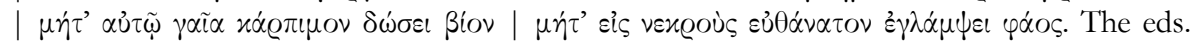
rightly suspect that the first part of the epigram was written for someone whose death was 
attributed to murder; the murderer is threatened with divine punishment; the second part

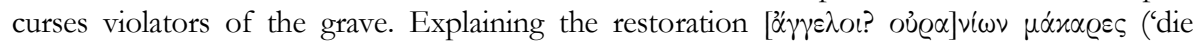
seligen Melder (Engel) der Himmlischen sind Rachegeister der Toten') M.-S. argue that the $\mu \dot{\alpha} x \alpha \varrho \varepsilon \varsigma$ were the souls of good men who functioned as divine messengers. [This is very doubtful; the first line is so badly preserved that it defies restoration and interpretation. Only the rest of the text is clear: 'There is an eye of justice and an eye of god cast on all mortals, which oversees everything and listens to all prayers. If someone does evil against this memorial, let the earth provide him with no fruitful life and let no light of good death shine among the dead']. For another epigram (p. 44f. nos 24-30) see supra no 42.

126) L. Migeotte, “À propos du gymnasiarque de Délos”, in O. CuRTY (ed.), L'buile et l'argent. Actes du colloque tenu à Fribourg du 13 au 15 octobre 2005, publiés en l'bonneur du Prof. Marcel Piérart à l'occasion de son 60ème anniversaire, Paris, 2009, p. 159-167 [BE 2010, 206]: M. discusses two passages of an honorary decree of the Athenian demos for the gymnasiarch Ptolemaios (Delos, SEG XLVII 1218, 157/6). Pausanias is honored for having offered sacrifices to all the gods and benefactors as required by laws and decrees. Who are the benefactors who received a cult on Delos? They cannot be local citizens or magistrates, since there are no honorary inscriptions for Delian citizens and magistrates in this period. Sacrifices to 'the gods and the benefactors' are, however, mentioned in ephebic inscriptions of Athens from 122/1 BCE on, and possibly as early as 162/1 BCE (restored). They were introduced already in the late 3rd cent. to honor Diogenes, the last commander of the Macedonian garrison, and Ptolemy III; the cult of great benefactors was associated with that of the Demos and the Charites. One may, therefore, assume that the sacrifices to benefactors, to which this decree refers, were introduced to Delos in 167. Pausanias is also honored for returning the money allocated to his office and covering the relevant expenses himself (lines 23-26: ๕̇

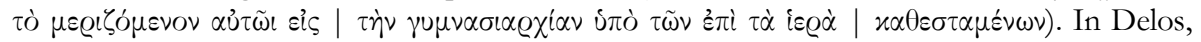

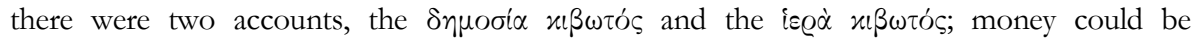
transferred from one to the other. Fonds were dedicated to specific tasks ( $v u \mu \nu \alpha \sigma \iota \varrho Q \chi w \alpha$,

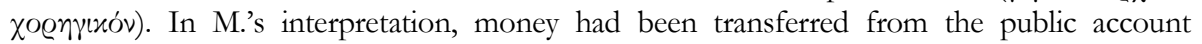

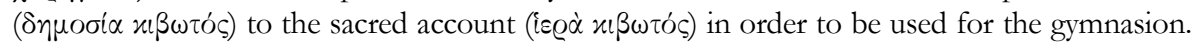
This probably was a regular allocation destined for contests. Since Pausanias had covered the expenses, he asked the magistrates responsible for the sacred account to return this amount to the public account.

127) A. MirAI, "Souls' Aitherial Abode According to the Poteidaia Epitaph and the Presocratic Philosophers", Numen 57 (2010), p. 553-582: M. associates the epigram for the war dead of the battle of Poteidaia (432 BCE; IG I ${ }^{3} 1179$ ) with Greek ideas about the afterlife as expressed in early philosophy and tragedy. He argues that the idea that the dwelling place of the soul was the aither, the upper region of the atmosphere, which was believed to be a divine realm, was common in the 6th and 5th cent.

128) C. MileTA, "Die prorömischen Kulte der Provinz Asia im Spannungsverhältnis von Religion und Politik", in Religion des Imperium Romanum, p. 139-160: Cults that expressed friendly feelings towards Rome and the Romans (the cult of Roma, the populus Romanus, the senate, and Roman magistrates) played an integral role in political communication between Rome and the province of Asia (late 2nd and 1st cent.). These cults followed the model of the ruler cult in Hellenistic cities with respect to ritual practices (celebration of a festival; cf. e.g. SEG XXXIX 1284). Unlike the Hellenistic ruler cult, which was limited to a single city and never had a regional character, some 'pro-Roman' cults were practiced throughout the province. The pentaeteric rhythm of these cults was probably influenced by the panhellenic festivals. M. examines the structure and development of such 'pro-Roman' cults in Asia (e.g. I.Metropolis 1). 
The civic cult of Dea Roma did not prevent most cities of Asia Minor from supporting Mithridates at the outset of the First Mithridatic War. The provincial 'pro-Roman' cults were a more effective medium of regular political communication between the province and Roman authorities. The early imperial cult was a mixture of Hellenistic traditions and the provincial 'pro-Roman' cults.

129) H. MÜLLER, "Ein Kultverein von Asklepiasten bei einem attalidischen Phrourion im Yüntağ", Chiron 40 (2010), p. 427-457 [BE 2011, 499]: Ed. pr. of an inscription from Yalaköy, southeast of Pergamon (ca. 200-150), which records the foundation of a cult association for

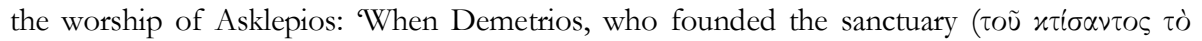
iع@óv), was the commander of the fort, for good fortune the first worshippers of Asklepios came together' ( $\sigma \cup \vee \tilde{\eta} \lambda \theta$ ov oi $\pi \varrho \tilde{\omega} \tau O \iota$ 'A $\sigma \sigma \lambda \lambda \eta \pi \iota \alpha \sigma \tau \alpha$ ); the names of 15 members were inscribed below this heading. The first name is that of the founder, Demetrios, son of Seuthes. The members of this association must have been soldiers serving in the fort's garrison. M. also publishes a second contemporary inscription from Yalaköy. It is a cult regulation with purity prescriptions: 'anyone who enters the sanctuary for health reasons must be pure from sexual intercourse, having washed himself from head to feet; from (contact with) a dead person and from a funeral two days later; from an abortion, for the same period of time. If someone

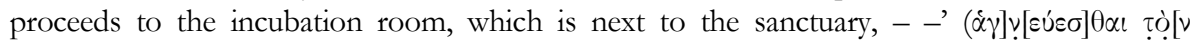

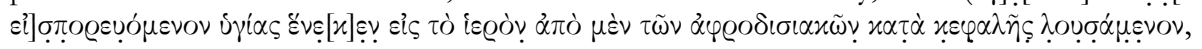

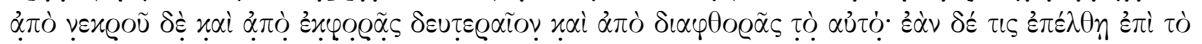

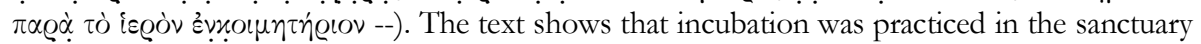
of Asklepios founded by Demetrios.

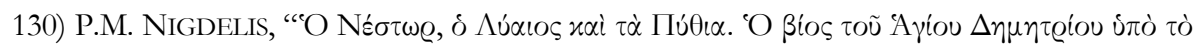

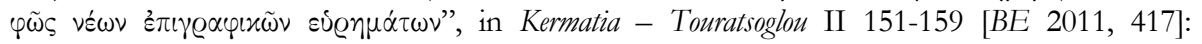
Adducing epigraphic evidence for gladiatorial games and festivals in Thessalonike and the hagiographical sources for the martyrium of St. Demetrios, N. argues that the festival during which the martyrium occurred must have been the Pythia. It is the only festival that combined a competition in the pentathlon with gladiatorial combats (SEG XLIX 815-819 + SEG LVI 748; cf. Patrologia Graeca 116; 1176 B). The most probable date is ca. 19-21 September 304 CE.

131) P. Nigdelis, "The Gens Varinia in Macedonia: On the Serrai Decree SEG LIV 617”, GRBS 49 (2009), p. 515-533: N. republishes an honorary inscription for Varinius Rebilus from Serrai, which dates to the late 1st cent. BCE/CE (SEG XXX 614 and LIV 617). The fragmentary decree provides for the celebration of Rebilus' birthday. It seems that Rebilus had made an endowment for this celebration; money was distributed to the demos on his birthday from the return of his bequest (cf. I.Cret. IV 300). His freedmen were invited (to the distribution or another celebration?). The presence of the word $\dot{\alpha}^{\prime} \gamma \alpha \lambda \mu \alpha$ in a fragmentary passage suggests that the erection of his statue was a condition for the distribution of the money, and not that the distribution took place in front of the statue; cf. TAM V.2.926; V.3.1457 and 1475) [in addition, the crowning of the statue can be reconciled with the accusative $\left.\left.\ddot{\alpha}^{\prime} \gamma \alpha \lambda \mu \alpha\right]\right)$. The members of the council and the assembly promised under oath $\left(\gamma \varepsilon[\nu] \circ \mu \varepsilon \varepsilon^{\prime} \omega \nu\right.$ èv[ó $\left.] \varkappa \omega \nu\right)$ to respect the conditions of the bequest (cf. I.Kibyra 43).

132) C. OesterHELD, Göttliche Botschaften für zweifelnde Menschen. Pragmatik und Orientierungsleistung der Apollo-Orakel von Klaros und Didyma in hellenistisch-römischer Zeit, Göttingen, 2008 [SEG LVIII 1300]: O. explores the impact of the oracles given by Apollo in Klaros and Didyma on the social life of the cities of Asia Minor. These oracles provided solutions to various crises (pestilence, earthquakes, bad harvests, conflicts, pirate attacks), gave advise (e.g. concerning building projects, the award of citizenship, and treaties), instructed on cultic matters (foundations of cults, rituals, appointment of religious officials), explained signs, and provided 
theological instruction. O. summarizes the various types of situations for which oracles were requested on p. 595-605. In an appendix, he provides a list of the known oracles from Klaros and Didyma (p. 570-592). He also discusses in detail numerous oracles (esp. MERKELBACHSTAUBER, SGO I nos $01 / 19 / 02$ and $22 ; 01 / 20 / 03 ; 01 / 23 / 02 ; 02 / 12 / 01-04 ; 03 / 02 / 01$; 04/01/01; 06/02/01; 08/01/01;09/01/01; 17/08/01).

133) P. ÖZLEM AYTAÇLAR, "Some Inscriptions in the Isparta Museum”, Gephyra 7 (2010), p. 11-21: Ed. pr. of a dedication to Poseidon from the modern village of Şarkikaraağaç in Pisidia (near Seleukeia Sidera; no. 1, Imperial period). The inscription is on an altar with relief decoration. Poseidon stands on a rounded object [a rock?] with a staff in his left hand and an indistinct object in his outstretched right hand; a dolphin decorates the right side of the altar, a river god the left.

134) P. ÖZLEM AYTAÇLAR, "Some Unpublished Inscriptions in the Isparta Museum", Adalya 13 (2010), p. 223-241 [BE 2011, 28, 578]: Ed. pr. of inscriptions of unknown provenance in the Isparta Museum (Pisidia, Imperial period). A man, having made a prayer, dedicated an

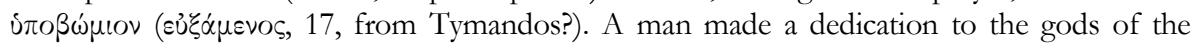

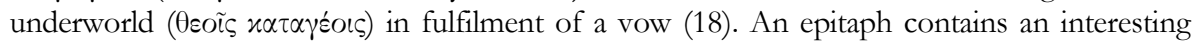
curse against violators of the grave. The culprits are 'donated'/devoted to Zeus Poteis $(\Delta \varepsilon \tilde{\imath}$

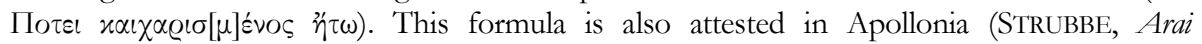

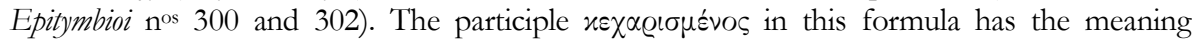
'accursed'; it may have been influenced by the Phrygian $\gamma \varepsilon \gamma \alpha \varrho \iota \tau \mu \varepsilon v o \varsigma$ formula. [It means that the violator is ceded to the god, i.e., he is subject to punishment by the god].

135) M. ÖZSAIT - G. LABARRE - N. ÖZSAIT, "Nouveaux témoignages sur le culte de Cybèle en Pisidie occidentale", Adalya 9 (2006), p. 1-31 [SEG LVI 1699]: The authors republish a votive rock-cut relief from the area of Diokaisareia (2nd/3rd cent.). The relief shows the bust of the dedicant, a naiskos with an ox head in the pediment, and Kybele enthroned within the naiskos; to the right, a lion strides toward the naiskos. On a lower level, a second relief depicts a man attacking a lion (a venatio?). The inscription (SEG XLVIII 1576) states that this was a dedication of Hieron to Meter Kadmene in fulfillment of a vow. The epithet of the goddess derives from a toponym (Mt. Kadmos?).

136) H.S. ÖZTÜrK - H. Perk, “A Votive Offering to Meter Tymenaia”, Adalya 12 (2009), p. 103-105: Ed. pr. of a dedication to Meter Tymenaia in fulfillment of a vow, reportedly from Fethiye in Lykia, now in a private museum (Imperial period). The cult of Meter Tymenene (from Mt. Tymenaion) is attested in Phrygia (SEG LII 1458) and Pisidian Antioch (SEG XXXV 1403).

137) M. ORNAGHI, La lira, la vacca e le donne insolenti. Contesti di recezione e promozione della figura e della poesia di Archiloco dall'arcaismo all'ellenismo, Alessandria, 2009: This study, dedicated to the reception of Archilochos and his poetry from the Archaic to the Hellenistic period, includes discussions of the cult of Demeter on Paros and Archilochos' connections with it (69-113; cf. IG XII.5.134, 226-227, 292); the transfer of cults from Paros to Thasos (p. 95-106; references to the altars for the cult of $\pi \alpha \tau \varrho \tilde{\omega}$ or $\theta \varepsilon o$ in in the Thesmophorion; an altar for the cult of

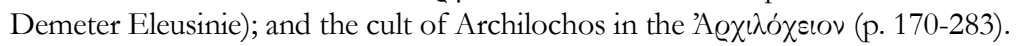

138) G. PACI, "Nuove iscrizioni da Cirene", in A. AKERrAz et al. (eds.), L'Africa romana. Mobilità delle persone e dei popoli, dinamiche migratorie, emigrazioni ed immigrazioni nelle province occidentali dell'Impero romano. Atti del XVI convegno di studio, Rabat, 15-19 dicembre 2004, Sassari, 2006, p. 1895-1903 [SEG LVI 2029]: Ed. pr. of an inscription recording the erection of a building or part of a building in the sanctuary of Apollo for the well being of emperor Trajan (ca. 97-115

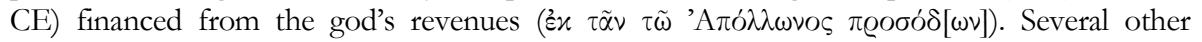


buildings are known to have been funded with Apollo's sacred money (Suppl.Epigr.Cir. 72; SEG IX 75,172,174). The building in question seems to have been the temple of Asklepios.

139) A. PaŁuchowski, "Note au sujet des Velchania de Lyttos (ICret I, 18 Lyttos, no 11)", DHA 31.1 (2005), p. 25-32: P. rightly observes that the correct sequence of the festivals $\Theta \varepsilon o \delta \alpha i \sigma i \alpha$ and $B \varepsilon \lambda \chi \alpha \dot{\alpha} \alpha \alpha$ is the one attested in an inscription from Lyttos (I.Cret. I.xviii.11;

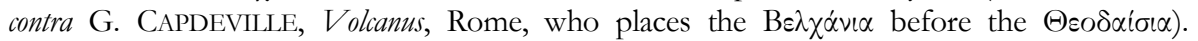
Assuming that these two festivals are connected with rites of passage, P. proposes that Theodaisia was the festival during which the new citizens were incorporated into the community and married, and the Velchania was the festival in which the young women were introduced into the home of their husbands.

140) A. PazuChowski, "La dédicace érigée à Ephèse par Antonius Vareius en l'honneur de C. Claudius Titianus Demostratus, ancien gouverneur de la province de Crète-Cyrénäque", ZPE 173 (2010), p. 107-115: An honorary inscription for a former governor of Crete and Cyrenaica was set up in Ephesos (SEG XLI 965, 2nd cent. CE) under the supervision of Antonius Vareius [- -]los, who served as a priest in Gortyn. P. suggests the restoration iعgè่s $\theta \varepsilon \circ \tilde{u}\left[{ }^{\prime} \Upsilon \Psi i\right] \sigma \tau O \cup$ (instead of $\left.[\Sigma \varepsilon \beta \alpha] \sigma \tau O \tilde{u}\right)$.

141) R. PARKER, “Tís o $\theta u ́ \omega v ; ”$, in Chemin faisant, p. 167-171: At the sacrifice, who sacrificed? The individual who brought the animal or the priest who carried out the ritual? Greek does not

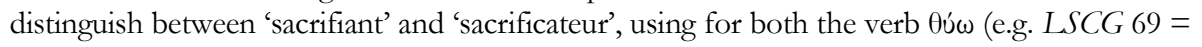
I.Oropos 277 lines 25-34; LSCG 119 lines 11-14). Because of this, in a sense, women did sacrifice. The verb $\theta \dot{\omega} \omega$ may denote both the priestly functions and the act of killing, which may be performed by a different individual (a Өútns); it may also encapsulate the entire group

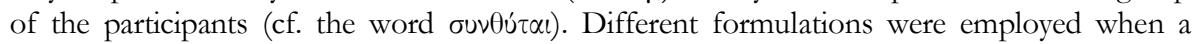

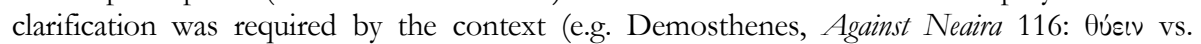

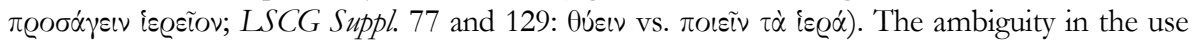
of $\theta \dot{u} \omega$ is connected with the complexity of sacrifice as an individual gift and a collective ritual action.

142) R. PArKer, "Eating Unsacrificed Meat", in Paysage et religion, p. 137-145: The Greeks ate meat that did not originate from sacrificial victims - the meat of game, of animals that were not sacrificed, and of animals that had died naturally $(\theta v \alpha \sigma i \delta \iota \alpha)$, although there exist ritual prescriptions against the consumption of the latter (e.g. LSCG 154 A 26). Some evidence supports the assumption that the main sacrificial species were sacrificed even when the real concern was meat (including the sale of meat in the market); but a simple slaughter in the market may also have occurred. The existence of rules in certain cult communities is attested

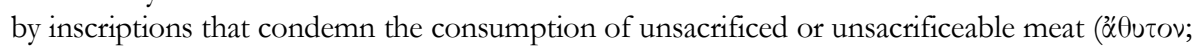
two confession inscriptions: PETZL, Beichtinschriften nos 1 and 123; a cult regulation from Smyrna: LSAM 84).

143) R. PARKer, “A Funerary Foundation from Hellenistic Lycia”, Chiron 40 (2010), p. 103121 [BE 2008, 484; SEG LVIII 1640]: P. discusses and re-interprets a lengthy inscription in a private collection in Fethiye (ca. 150) [see supra no 98]. The text originally came either from Tlos, where the civic subdivisions of the 'Bellerephonteans', 'Iobateans', and 'Sarpedonians' are attested (all of them named after heroes known from Homer), or from Xanthos, where the cult of Leto was prominent. The text details the conditions under which a certain Symmasis donated a sum of money to an association of metalworkers. Honorary shares of the sacrificial victim were to be given to the donor and his wife; family members were to attend banquets; and the funds were to be properly administered, avoiding misappropriation. Symmasis' offer (inscribed on side A of the stone) provides for an honorary share of the sacrificial animal, 


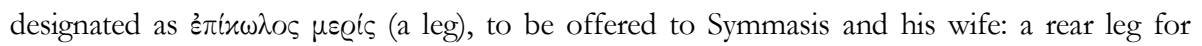

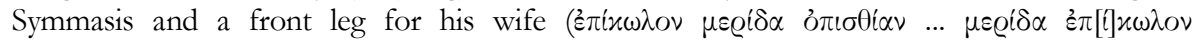

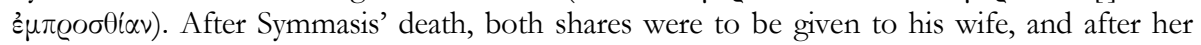
demise to their sons and their descendants. Up to ten family members were to attend the banquets ( $\varepsilon \dot{v} \omega \iota \chi^{i}(\alpha)$ ): his three sons, two sons-in-law, and their eldest sons, until the number ten was reached. Each time a member of the group died, the deceased was replaced by the eldest descendant. Symmasis' clear intention was to create a self-renewing cell of male descendants who would continue the cult in perpetuity [this group of ten males may have been influenced by the institution of the $\delta \varepsilon x \alpha v i \alpha]$; women were excluded from the sacrifice and the banquet, and the expression $\pi \alpha \varrho \alpha \theta \dot{\eta} \sigma o v \sigma \iota \nu \sum u \mu \mu \alpha \sigma \varepsilon \iota$ suggests that Symmasis was also given his wife's portion to take away. Disputes concerning this right were to be resolved by the association in a meeting convened in Leto's sanctuary. Any violations of these terms by the association resulted in the payment of a fine to Helios. A war or another political crisis ( was an acceptable cause for not holding the sacrifices and the banquets at the prescribed time,

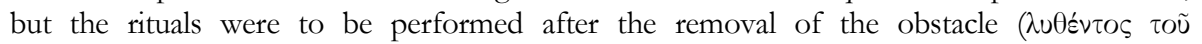
$\varkappa \omega \lambda \dot{\mu} \mu \alpha \tau \sigma \varsigma)$. The text continues after a lacuna on side B. The repetition of formulations that also appear on side A supports the conclusion that this side contains the document with which the association accepted (after some modifications?) Symmasis' offer. [Because of the fragmentary state of the inscription, this is not absolutely certain. There is not an exact correspondence between the sacrifice described on side A and the two sacrifices mentioned on side B. In the document on side B, Symmasis refers to his relatives by using pronouns in the first person (B 24, 44), but these formulations may have been copied from the original offer]. The original endowment was to remain untouched, and the sacrifices were to be funded from

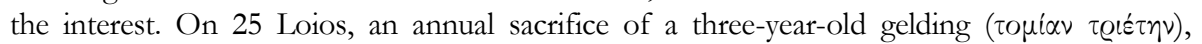

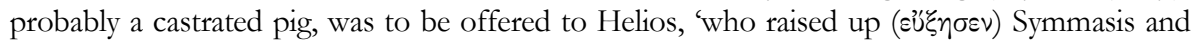
his wife', in an unknown location. Symmasis' expression of indebtedness to Helios is striking; it may refer to physical growth, wellbeing, and prosperity. We need not assume that the cult of Helios was introduced in Lykia under Rhodian influence. The feast, possibly on Symmasis'

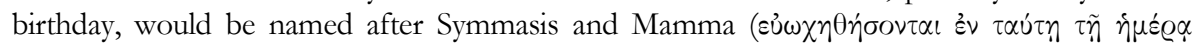

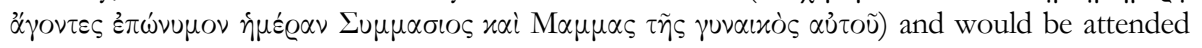
by Symmasis' three sons and his two sons-in-law. Another sacrifice, this time of a goat or a

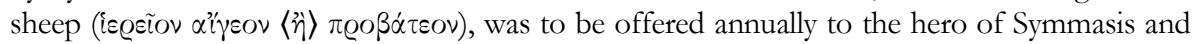
Mamma by the elected magistrates of the association, on the altar that Symmasis was to erect. The 'hero of Symmasis and Mamma' was not a hero to whom Symmasis and Mamma were especially devoted' but rather something closely associated with themselves: 'that within Symmasis and Mamma which will allow them to survive as heroes after their death', a kind of potentiality within them. In Karia, we frequently find references to the $\delta \alpha i \mu \omega \nu, \dot{\alpha} \gamma \alpha \theta \dot{o} \varsigma \delta \alpha i \mu \omega \nu$, or $\alpha \gamma \alpha \theta o i \delta \alpha u$ óveৎ of the dead. [A close parallel is provided by the honorary decree for Leros from Lagina (SEG LII 1064; see my comments in EBGR 2009, 138). An altar and a precinct of the daimon of Leros and his wife Kosina, where a priest offered a sacrifice on behalf of the

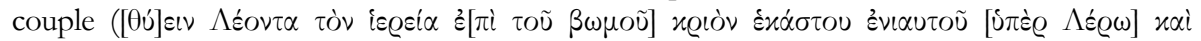

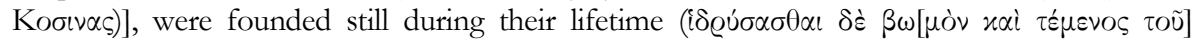

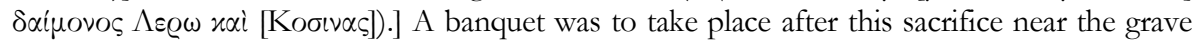
(of Symmasis and Mamma), attended by the administrators of the fund, the magistrates of the association, and Symmasis' relatives. During his lifetime, Symmasis received an additional portion of the victim, from the rear leg; after his death, this portion was given to his sons and their descendants. The endowment stipulates that any violators would be 'guilty before the Sun

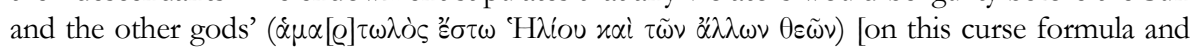
its Lykian origin see infra $\left.n^{\circ} 174\right]$ and liable to fines. The text then deals with the protection of Symmasis' grave against unauthorized burials. An unusual feature of this inscription is that the 
members of the koinon were not beneficiaries of the endowment; only the archons were expected to attend the annual banquet. Perhaps the koinon undertook the responsibility of the endowment's supervision, because Symmasis, certainly a member of the association, was its benefactor in some way that is not revealed by the preserved text. P. comments on Greek and Lykian traditions concerning the periodic commemoration of the dead. In contrast to Greek commemorative offerings, deposited by relatives on the tomb, Lykian offerings could be occasions for a banquet at the tomb. Symmasis' endowment differs from the Lykian tradition in that he established a mechanism designed to ensure that the sacrifice was actually carried out: he inaugurated the commemorative feast in his own lifetime and he associated it with a sacrifice to a god, the Sun. These features correspond to more general Hellenistic trends of 'heroisation by private initiative' [on the legal aspects see the analysis of I. ARNAOUTOGLOU, "Cultural Transfer and Law in Hellenistic Lycia: The Case of Symasis' Foundation", in B. LEgras (ed.), Transferts culturels et droits dans le monde Grec et bellénistique. Actes du colloque international (Reims, 14-17 mai 2008), Paris, 2012, p. 205-214].

144) I. PATERA, "Theoi sumbômoi et autels multiples. Réflexions sur les structures sacrificielles partagées", Kernos 23 (2010), p. 223-238: P. studies the abundant epigraphic evidence for altars shared by two or more deities ( $\theta \varepsilon o i$ ó $\mu \beta \omega \dot{\omega} \mu \iota$ or $\sigma \dot{\mu} \mu \beta \omega \mu \mathrm{o})$. She argues that this phenomenon is very heterogeneous and cannot be explained by the dichotomy between Olympian and chthonian rites.

145) L.E. Patterson, “An Aetolian Local Myth in Pausanias?”, Mnemosyne 57 (2004), p. 346352: An Aitolian decree in Delphi (IG IX 2.1 .173 , ca. 259-255) concerns the acceptance of Herakleia in the Aitolian Koinon. The Aitolians promise to assist the Herakleiotans in their

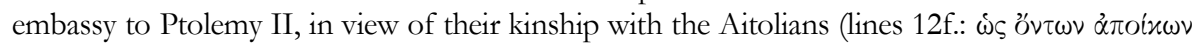

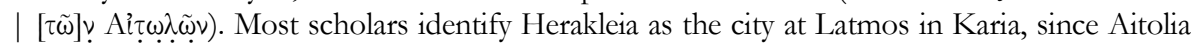
and Herakleia at Latmos shared a myth involving Endymion (Paus. V, 5, 1; Strabo XIV, 1, 8). P. confirms this identification. Endymion was regarded as the founder of Herakleia at Latmos. After reviewing Eleian and Aitolian legends dealing with Aitolian migrations in Elis (the myths of Aitolos, the son of Endymion, and Oxylos, a descendant of Aitolos), he argues that they vaguely reflect post-Mycenaean movements.

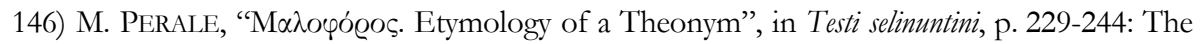
cult epithet Malophoros, attested in Selinous (IGDS 78 and Arena $n^{\circ} 38$ ) and in Anchialos (IGBulg $\mathrm{I}^{2} 370$ bis), derives from the word $\mu \tilde{\alpha} \lambda$ ov, which more probably is the Doric form for apple $(\mu \tilde{\eta} \lambda \mathrm{ov})$ rather than a hyper-Doric form of $\mu \tilde{\eta} \lambda o v$, i.e. 'sheep'. Hyper-dorisms cannot be expected in the Archaic period.

147) S. Perrot, "Pommes agonistiques à Delphes. Réflexions autour du cognassier sacré d'Apollon", BCH 133 (2009), p. 153-168: The $\mu \tilde{\eta} \lambda \alpha$ Пu$\theta$ wx $\alpha$, given as a prize to winners at the Pythia, were produced through the grafting of an apple tree with a quince tree - the latter was associated with Crete. The decision to introduce this award may be attributed to Hadrian, possibly in connection with his efforts to revive the Pythia. An Attic dedicatory epigram (IG $\mathrm{II}^{2}$ 3158), dedicated by Onetor to Apollo, refers to $\mu \tilde{\eta} \lambda \alpha, \sigma \eta_{\mu} \mu \alpha \alpha$ vix门s. [Hadrian cannot possibly be the one who introduced this award. Both Chariton, Chaireas and Kallirhoe VI, 2, 2, who mentions this award, and Onetor's dedication antedate Hadrian's reign.]

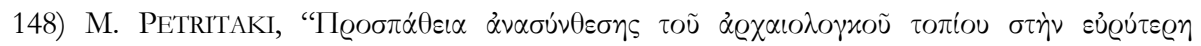

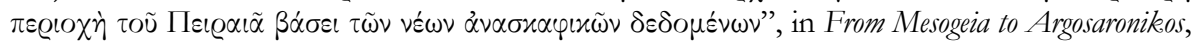
p. 451-480 [BE 2010, 223]: P. mentions the discovery of five lead tablets placed in the grave of a cremated woman at Agios Ioannis Rentis (near Piraeus; p. 464f.). All the tablets are pierced with nails. Four of them are inscribed with curses directed against different persons; except for 
the names, the texts of the curses are the same. The chthonic gods Hekate Chthonia, Artemis Chthonia, and Hermes Chthonios are asked to resent men and their business (p. 465). P. gives

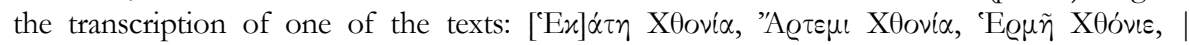

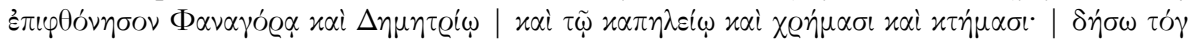

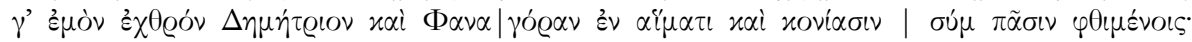

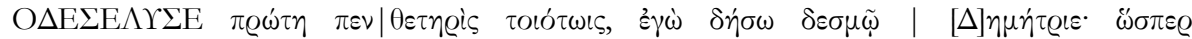

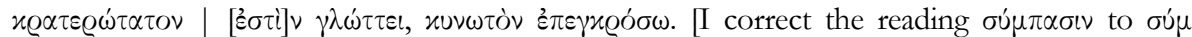

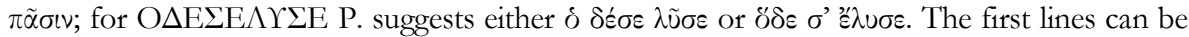
translated. 'Hekate Chthonia, Artemis Chthonia, Hermes Chthonios, resent Phanagoras and Demetrios and their stand and their property. I shall bind my enemy Demetrios and Phanagoras in blood and dust together with all the dead'. The rest is not clear. There is a reference to $\pi \varrho \omega \dot{\tau} \eta \pi \varepsilon v \theta \varepsilon \tau \eta \varrho i s$, i.e. the first (or next) Olympic cycle. Then the defigens addresses his victim directly (an unusual feature in defixiones): 'thus I shall bind (you),

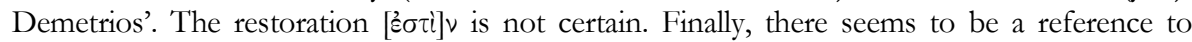

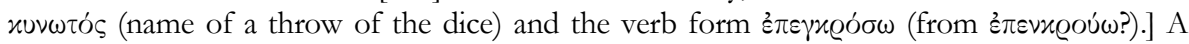
marble lekythos placed on the grave of an athlete (a member of the family of Lysis, a friend of Sokrates) reports his victories in chariot races and in horse races at the Isthmia (three times), the Nemea (three times), the Pythia, and the Panathenaia (p. 466f.). The name of an agonistic festival is given by the mason as NEA ('I $\sigma \theta \mu \alpha \alpha$ NEA Пú $\theta \iota \alpha$ etc.). [C. FEYEL, BE 2010, 223, suggests the reading $N \varepsilon \dot{\varepsilon}<\mu \varepsilon>\alpha$.] A new a sanctuary of Kybele was excavated in Neo Phalero, where a statue of the goddess was found, dedicated by Hipparete, the wife of Alcibiades (p. 469).

149) N. Petrochilos, "A Bilingual Dedication to the Mother of the Gods", ZPE 175 (2010), p. 158-160: Ed. pr. of an inscribed altar (Andros, early 1st cent.). A freedman made a bilingual dedication to Meter Theon. The dedicant thanks the goddess for saving him, using the unusual

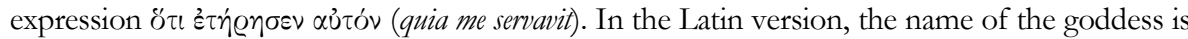
a transliteration of the Greek: Metrei Theon (not Matri Deorum).

150) A. Petrovic, "Sepulchral Epigram for Philadelphos (A Fallen Soldier?)", Mnemosyne 63 (2010), p. 616-624: Ed. pr. of a funerary epigram from Aphrodisias (late 2nd cent. CE). A mother erected a cenotaph for her son, Philadelphos, who died abroad, possibly in a war. In

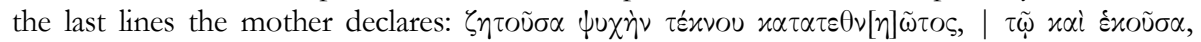

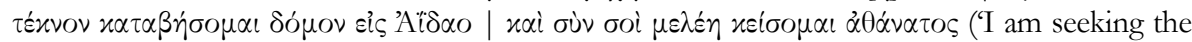
soul of my deceased child, and because of this, of my own free will, I shall, my child, descend to the house of Hades. With you I will rest, forever wretched'). As P. plausibly assumes, the mother, unable to bury the body of her son, decided to commit suicide; $\dot{\alpha} \theta \dot{\alpha} v \alpha \tau$ cos is not used in the usual sense of 'immortal', but rather to mean 'perpetual' (referring to the mother's eternal lament). [Republished with commentary by A. CHANIOTIS, "Inscriptions", in C. RATTÉ - P. D. De Staebler (eds.), Aphrodisias V. The Aphrodisias Regional Survey, Darmstadt-Mainz,

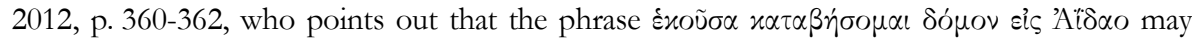
imply indifference toward death, not suicide].

151) O. PICARD, "Le décret amphictionique sur le tétradrachme stéphanéphore et les technites", in Kermatia - Touratsoglou I, p. 33-43: P. studies the amphiktyonic decree concerning the acceptance of the Athenian tetradrachm (Delphi, late 2nd cent.; F.Delphes III.2.139; CID IV 127). He argues that the main beneficiaries of this decree were the Dionysiac artists, and especially the Athenian branch of their association. The technitai received the compensation for their services in $\pi \alpha \vee \eta \gamma$ vesı in Athenian tetradrachms.

152) S. Pingiatoglou, "Cults of Female Deities at Dion”, Kernos 23 (2010), p. 170-192: P. assembles the archaeological and textual evidence for the cult of goddesses in Dion: the Muses 
(SEG XLIX 697), Demeter, Praxidika (unpublished inscription), Eileithyia (unpublished inscription), Hygieia, Isis, Aphrodite, and Athena. Isis, whose cult was introduced in the 2nd cent., gradually overshadowed that of the other deities; Isis possessed several of the qualities of some of the older goddesses.

153) L. Piolot, “À l'ombre des maris”, in Chemin faisant, p. 87-113 [BE 2011, 125]: P. examines the duties of the yuvaıovónor in Greek cities. Its introduction in Athens is usually attributed to Demetrios of Phaleron, but Lykourgos is an attractive alternative. P. discusses in detail the duties of the gynaikonomoi in festivals and rituals, adducing the funerary regulation of Gambreion ( $L S A M$ 16) the mystery inscription from Andania (IG V.1.1390), and the regulation of Methymna concerning sacrifices in a mystery cult accessible only to women (LSAM 127). As regards the mysteries of Andania, P. discusses in detail the regulations concerning the dress of the $\tau \varepsilon \lambda$ oú $\mu \varepsilon v o$. He rightly observes that this term comprises all the individuals that participated in the ceremony, not only those who were to be initiated. The rules pertaining to women's dress should be explained in view of both social (limitation of luxury) and ritual considerations [for the role of gynaikonomoi in festivals see also I.Magnesia 98 line 20].

154) V. Pirenne-Delforge, "Des marmites pour un méchant petit hermès! ou comment consacrer une statue", in S. ESTIENNE et al. (eds.), Image et religion dans l'Antiquité gréco-romaine, Naples, 2008, p. 103-110: Little is known about ceremonies and rituals that accompanied the

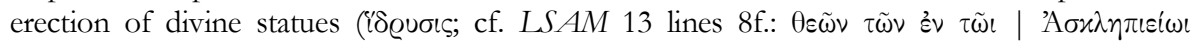

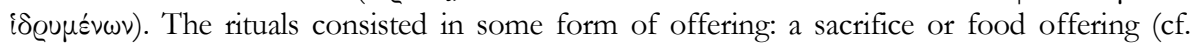

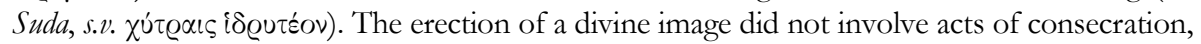
i.e., the investment of the image with a divine status. It signified the integration of the deity into the city or a cult community; it created the conditions for the deity to manifest his/her power (cf. the ceremony in Magnesia on the Maeander for the installation of the xoanon of Artemis Leukophryene: LSAM 33). The use of symbols and 'signs' ( $\approx \eta \mu \varepsilon i \alpha)$ implied the

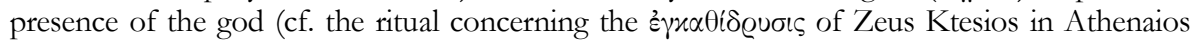
XI, 473b-c). The prayers that accompanied the sacrifices (Harpokration, s.v. ¿̇ $\xi \alpha \alpha \dot{\alpha} \sigma \alpha \sigma \theta \alpha \iota)$ may have included utterances of the god's identity. The dedication of a divine statue $(\dot{\alpha} \nu \dot{\alpha} \theta \eta \mu \alpha)$, which made it to the property of a god, should be distinguished from its erection (iogvoıc) as a sign of the god.

155) V. Pirenne-Delforge, "Mnasistratos, the 'Hierophant' at Andania (IG 5.1.1390 and Syll. 3 735", in J. DijKSTRA et al. (eds.), Myths, Martyrs, and Modernity. Studies in the History of Religions in Honour of Jan N. Bremmer, Leiden, 2010, p. 219-235: Mnasistratos is the only participant explicitly named in the cult regulation concerning the mysteries of Andania (IG V.1.1390). The inscription states that he had transmitted the 'books' to the bieroi and that he was in charge of the spring named Hagna and a statue of the eponymous goddess of the spring; he was to attend the mysteries and the sacrifices, receiving a share of the victims and some cash from the thesauroi. It is widely believed that Mnasistratos was member of the family that had been in charge of the mysteries for centuries. A certain Mnasistratos (presumably the same Mnasistratos) was the envoy sent by Messene to Argos in order to receive an oracle from Apollo Pythaios concerning a sacrifice to the Megaloi Theoi and the performance of mysteries (Syll. ${ }^{3}$ 735). In this text, he is designated as a hierophantas. If one accepts the dating of the Andania regulation to $24 \mathrm{CE}$ (instead of $91 \mathrm{BCE}$ ), then Mnasistratos was also a benefactor honoured by Messene for his contribution to the imperial cult in 42 CE (SEG XXIII 208). An analysis of the Andania regulation shows that there is surprisingly little reference to customary practices. The absence of any reference to antiquity or custom with respect to the books that were delivered by Mnasistratos is particularly striking; it may be explained, if one assumes that 
these books were not 'sacred books' but were instead the result of an erudite investigation conducted by Mnasistratos in order to enhance the prestige of the ancient cult. Mnasistratos' work combined elements of benefaction, ritual expertise, devotion to a cult, and erudite exploration. He structured a telete on the basis of existing cults and antiquarian investigations. 'In this sense, he was the founder of the cult. The establishment of these mysteries had, therefore, to be endorsed by an oracular command' (p. 233). There is no evidence for the assumption that Mnasistratos belonged to a sacerdotal family of hierophants prior to the Andanian regulation or that he held this office afterwards. An inscription dating to Augustus' reign reveals a connection between the cult in Andania and the imperial cult (SEG XLIII 163). If the new dating of the regulation is correct, then the association between the Great Gods and the emperor predates and possibly explains the Mnasistratos' initiative. P. also discusses a new inscription from Messene (3rd cent.) that mentions a Karneiastas and six bieroi, whom P. Themelis interpreted as initiates [see infra $\mathrm{n}^{\circ}$ 190]. This would imply that mysteries were performed in the Karneiasion of Andania in the early 3rd cent. BCE, for which there is no other evidence (p. 226-228).

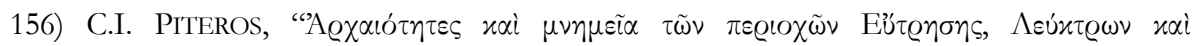

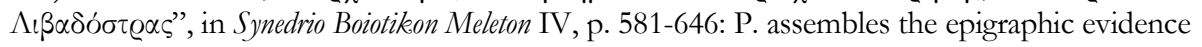
for the cult of Herakles Leuktriades, who was worshipped near the trophy of the battle at Leuktra (SEG XXVII 59 and IG VII 1829; p. 594-598).

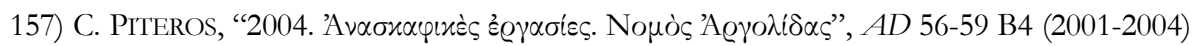
[2012], p. 59-63: Ed. pr. of an offering table dedicated to Artemis by two Corinthians (Argos, 4th cent.). The find was made at the site of a hitherto unknown sanctuary of Artemis.

158) R. POSAMENTIR - M. WÖRRLE, "Der Zeustempel von Aizanoi, ein Großbau flavischer Zeit", MDAI(I) 56 (2006), p. 227-246 [SEG LVIII 1492]: The dedicatory inscription of the temple of Zeus in Aizanoi is not preserved, but the rivet-holes for the support of bronze letters permit a tentative reconstruction. It seems that the temple was dedicated to Zeus Aizanon and Emperor Domitian in $92 \mathrm{CE}$.

159) D.M. PritChARD, "Costing the Great Panathenaia in the Early Fourth Century BC", Classicum 35 (2009), p. 8-15: Drawing from all available sources, P. estimates the cost of the Great Panathenaia in ca. 380 BCE to have been 25 talents and 725 drachmas; approximately half of this amount was covered by liturgies [cf. D.M. PRITCHARD, "Costing Festivals and War: Spending Priorities of the Athenian Democracy”, Historia 61 (2012), p. 18-65].

160) M. RICL, "Report on the Results of an Epigraphic Survey in the Cayster Valley in October 2008”, DHA 35.2 (2009), p. 182-185: Report on the discovery of 11 unpublished inscriptions in the Kaystros Valley during a field survey. They include the epitaph of a woman who is

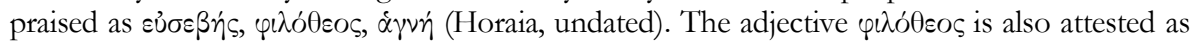
the name of a cult association in Hypaipa (SEG XXX $1382 \mathrm{C}$ ) and as a designation of dedicants to Mes in Lydia (TAM V.1.457).

161) M. RICL, "Greek Inscriptions in the Museum of Tire (Turkey)", DHA 35.2 (2009), p. 186-189: The unpublished inscriptions from the Kaystros Valley kept in the Museum of Tire include dedications to Zeus Soter Karpodotes, Hekate, Kybele, Apollo (Letoides), and an anonymous deity. A boundary stone of an estate belonging to Artemis Ephesia (from Turgutlu), erected according to the orders of Emperor Trajan, is the exact copy of another boundary stone (I.Ephesos 3511).

162) K.J. RigsBy, "Merops the Founder: I.Olympia 53", ZPE 173 (2010), p. 89-90: A fragmentary decree from Olympia praises Augustus for the restoration of the cities of Asia after the earthquake of $26 \mathrm{BCE}$ (I.Olympia 53). R. rejects the assumption that the decree was 
issued by Kos and refers to Merops, its mythical founder. He attributes the decree to Sardes. The Sardians praise Augustus: by taking upon himself the construction of the city, he surpassed even Merops - not the founder of Kos but rather the founder of mankind after the flood.

163) K.J. RigsBy, "Cos and the Milesian Didymeia", ZPE 175 (2010), p. 155-157 [BE 2012, 333]: A Koan inscription of the late 3rd cent. (IG XII.4.153-154) contains a Milesian decree requesting the recognition of the Didymeia as a crown contest and the Koan response to it.

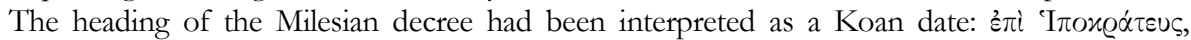

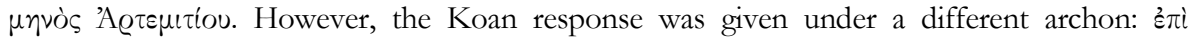

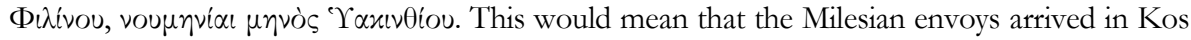
in Artamitios and received a response two months later, in Hyakinthios; that there were different eponymous archons in these two months would imply that Artamitios was the last or penultimate month of the Koan year (not the sixth month, according to the generally accepted reconstruction of the Koan calendar). These difficulties disappear, however, if one assumes that the mason did not inscribe a Koan date, but instead misunderstood a Milesian one: é $\pi i$

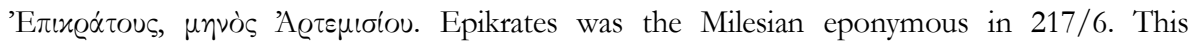
provides a date for the upgrade of the Didymeia and the dispatch of theoroi in 216 BCE. The first celebration of the agon was in 215 (year 2 of an Olympic cycle).

164) A. RoBU, "Réflexions sur le culte d'Apollon à Chalcédoine", LEC 75 (2007), p. 137-155: The great significance of the cult of Apollo Pythios in Megara, known from literary and epigraphic sources, also explains its prominence in Kalchedon, a Megarian colony. The

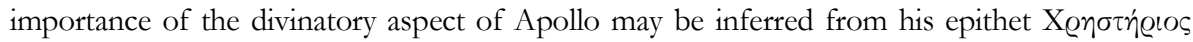
and from the legends that credited Kalchas or his son Kalchedon with the foundation of Kalchedon. Apollo's cult is known from coins, inscriptions, and literary sources. The priest

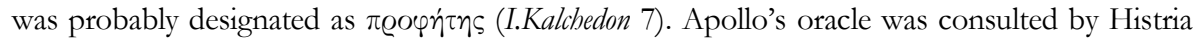
in the matter of the introduction of the cult of Sarapis (I.Histriae 5). In the late 3rd cent. the sanctuary of Apollo was recognized as inviolable by Delphi, and later also by Phokaia and Tenedos (RigsBy, Asylia 62-64). The Delphic recognition uses the epithet Pythaios (RIGSBY, Asylia 62), whereas the recognition decree of Phokaia calls Apollo Chresterios (RigsBY, Asylia 63). The two different epithets and the fact that the Delphic recognition refers to a sanctuary in the territory of Kalchedon ( $(\xi \mu \tau \tilde{\alpha} l$ K $\alpha \lambda \chi \alpha \delta o v i \alpha l)$ led K. Rigsby to presume that there were two sanctuaries, one of Apollo Pythaios in the territory, and another of Apollo Chresterios in the city, where the recognition decrees of Phokaia and Tenedos were found (Moda Hill). R. argues that there is no firm evidence for this. He assumes that there was only one extra-urban sanctuary and explains the two different epithets as referring to different cult images of Apollo within the same precinct. [The importance of Apollo Pythios in Megara leaves little doubt that this was the god's epithet when the colonists brought his cult to the new city. When the Phokaieis recognized the inviolability of the sanctuary of Apollo Chresterios, they did so in response to a Kalchedonian document that used this designation (on this practice see A. CHANIOTIS, "Empfängerformular und Urkundenfälschung: Bemerkungen zum Urkundendossier von Magnesia am Mäander", in R.G. KHOURY (ed.), Urkunden und Urkundenformulare im Klassischen Altertum und in den orientalischen Kulturen, Heidelberg, 1999, p. 51-69). Chresterios must have been the epithet under which Apollo was worshipped around $200 \mathrm{BCE}$, and not the designation of one of his statues randomly chosen by the Phokaians. Why, then, is Apollo called Pythaios in the Delphic document? He was called this either because there was a second sanctuary (as assumed by K. Rigbsy) or, perhaps more likely, because the author of the Delphic decree (or the Kalchedonian envoys to Delphi) chose an epithet that highlighted the relation between the Apollo in Delphi and the one in Kalchedon]. 


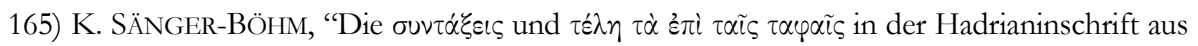
Alexandria Troas", ZPE 175 (2010), p. 167-170: The author discusses two legal terms in the letters of Hadrian that concern the organization of contests and the rights and privileges of the victors (SEG LVI 1359; EBGR 2007, 111; 2008, 56; 2009, 147). Papyrological evidence for the use of $\sigma u v \tau \dot{\alpha} \xi \varepsilon \mid \zeta$ confirms the assumption that they were monetary contributions given to the victors by their cities on a regular basis and not one-time cash prizes. Victors were also freed

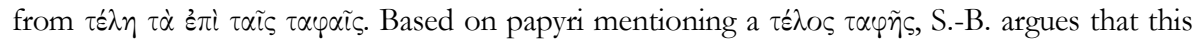
term does not refer to burial expenses (as previously assumed) but to a burial tax in the victors' cities of origin, from which the victors were exempt.

166) H. ŞAHIN, "A New Dedication to Athena from Diocaisarea (Uzumburç)", Adalya 12 (2009), p. 221-230: Ed. pr. of an altar dedicated to Athena by a Roman soldier after a prayer

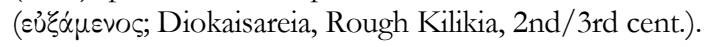

167) S. ŞAHIN, "Parerga zum Stadiasmus Patarensis (3). Die Inschrift von Köybaşi in Zentrallykien", Gephyra 7 (2010), p. 137-152: S. raises doubts on the reading and restoration of an honorary inscription from Lykia (infra no 175), which attests the cult of the Proimoi Theoi.

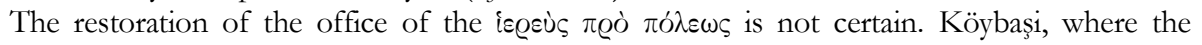
inscription was found, should be assigned to the territory of Xanthos, not Patara.

168) S. ŞAHIN, "Korrektur zu den Bau und Widmungsinschriften des Ekklesiasterions und Bouleuterions von Perge", Gephyra 7 (2010), p. 161-163: Ş. presents the text of two building inscriptions from Perge, which had been published with many typographical errors (S. ŞAHIN, "Die Inschriften", in H. ABBSOĞLU - W. MArTinini (eds.), Die Akropolis von Perge I, Mainz, 2004, 167-171 and ID., "Ekklesiasterion und Bouleuterion von Perge", Kölner Jabrb. 43, 643654). Two brothers, one of whom served as priest of Artemis, provided the funds for restoration and construction works in the assembly hall and the town hall of Perge.

169) I. SALVO, “Textual Notes on the Chian Decree SEG XXX 1073”, ZPE 172 (2010), p. 7073 [BE 2012, 340]: An honorary decree for an anonymous benefactor (Chios, shortly after 188 BCE; SEG XXX 1073) mentions, among the man's services, the dedication to Dea Roma of a work which presented a version of the birth of Romulus and Remus. According to this version, their father was Ares. The term used to describe this work is not preserved. S.

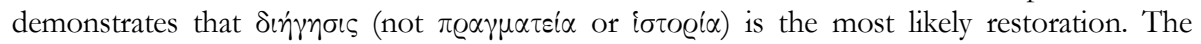
dedication seems to have been a narration of the origins of Rome that combined text and visual representation.

170) P. SÁNCHEZ - P. SCHUbERT - Y. VOLOKHINE, "Une dédicace grecque de l'époque impériale tardive trouvée à Hermonthis (Ermant, Haute Égypte)”, ZPE 174 (2010), p. 127-132 [BE 2011, 638]: Ed. pr. of a dedication (Hermonthis, mid-4th cent. CE). A supervisor of a

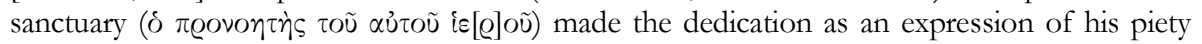

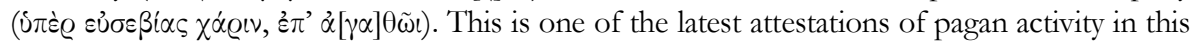
area.

171) A.C. SCAFuro, "The Crowning of Amphiaraos", in Greek History and Epigraphy, p. 59-86: S. considers an Athenian decree proposed by Phanodemos, according to which Amphiaraos should be crowned with a golden crown (I.Oropos 296, 332/1 B.C.). Although the private crowning of statues of gods and heroes is very common, to bestow such an honour upon a god through a civic decree is unique. The clause stipulating that the crown should be dedicated by the epimeletai in Amphiaraos' sanctuary leads S. to assume that the crowing was symbolic, akin to that of foreign dignitaries, whose crowing was proclaimed. Unlike mortals, who reciprocated the honour by dedicating their crown elsewhere, Amphiaraos could not do this; this is why the epimeletai dedicated the crown in his own sanctuary. Phanodemos complement- 
ed the crowning with a prayer ('to dedicate the crown to the god for the health and protection of the demos of the Athenians and for their children and wives and of everybody in the land'), which had a political significance. Having offered the sanctuary as a gift, the Athenians 'show their regard for the sanctuary with an honorary decree which pays heed to the foreignness and divinity of Amphiaraos' (p. 77). On 59f., C. assembles the inscriptions that refer to Phanodemos' religious activities: he proposed a dedication to Hephaistos and Athena ( $I G \mathrm{II}^{2} 223$, ca. 340); he was a member of the committee that organized the Amphiareia in 329 BCE (I.Oropos 298); and he contributed to dedications to Amphiaraos in 328 (I.Oropos 299) and to Apollo (Syll. ${ }^{3}$ 296).

172) P. SCHERRER, "Die Stadt als Festplatz. Das Beispiel der ephesischen Bauprogramme rund um die Kaiserneokorien Domitians und Hadrians", in Festrituale, p. 35-65: S. explores the impact that the award of neokoriai to Ephesos under Domitian and Hadrian (84-131 CE) and observance of the imperial cult had on the architectural development of the city (construction of temples, other public buildings, recreational areas); he cites the epigraphic evidence for these building projects and the part that benefactors played in them.

173) S. SCHEubLE, "Loyalitätsbekundungen ptolemäischer Phrurarchen im Spiegel epigraphischer Quellen", in Identität und Zugehörigkeit, p. 35-53: S. assembles honorary and dedicatory inscriptions set up by commanders of Ptolemaic garrisons in Egypt, Palaestina, Cyprus, and Crete as expressions of loyalty.

174) D. SCHÜRR, "Eine lykische Fluchformel mit Zukunft", EA 43 (2010), p. 149-158: The

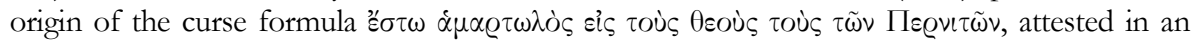

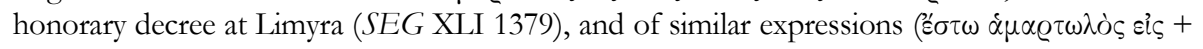

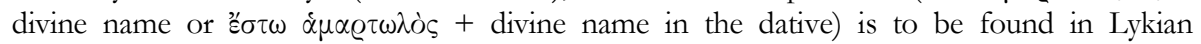
imprecations.

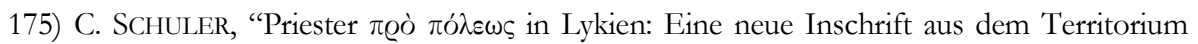
von Patara”, ZPE 173 (2010), p. 69-86 [BE 2011, 557]: Ed. pr. of an honorary inscription from an ancient settlement at Köybaşi (territory of Patara, 1st cent. BCE/CE). A woman dedicated to the gods a statue of her husband, who had served as priest of an anonymous deity (Apollo?,

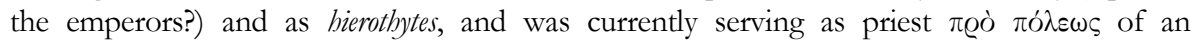

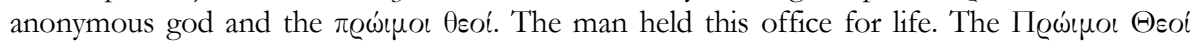
(gods associated with the early morning or early fruits?) are also attested in Myra (SEG LVIII 1605) [see supra $\mathrm{n}^{\circ}$ 41]. S. discusses in detail the evidence for priests and gods who were

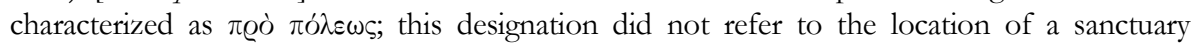
outside the city but indicated the public character of the cult, the special status of the priesthood, and the status of a divinity as patron of a city [cf. supra no 167].

176) C. SCHULER, "Die griechischen Inscriften von Phellos", MDAI(I) 55 (2005), p. 250-269 [SEG LV 1481, 1483, 1484, 1488]: 1) Ed. pr. of an inscription that records the dedication of the theater to Dionysos and the demos by a benefactor (1, 2nd cent.). 2) Ed. pr. of a posthumous honorary statue of Aurelius Straton (3, early 3rd cent. CE). The statue was dedicated to the gods by his father, a former priest of Tiberius in the Lykian Koinon. 3) S. republishes the honorary inscriptions for Arsinoe and her hudband Menekles, who had dedicated their statues to the gods (4, IGR III 867, 1st cent.). Menekles had served as priest of Thea Rhome propoleos. 4) Ed. pr. of the epitaph of a slave and his family members $(8,2$ nd cent. CE). Violators of the grave are threatened with punishment by the gods of the underworld ( $\dot{\varepsilon} \dot{\alpha} \nu \delta \varepsilon \dot{\varepsilon} \tau\langle\varsigma\rangle) \pi \alpha \varrho \dot{\alpha} \tau \alpha \tilde{u} \tau \alpha$

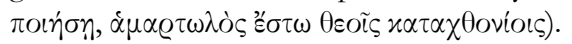

177) G. Scibone - G. Tigano, Halaisa-Alesa, Messina, 2009: On p. 97-112, the authors present the ed. pr. of a very interesting and puzzling Hellenistic document inscribed on a 
bronze tablet. The tablet contains a decree of the assembly (balia) and 'the council, the one

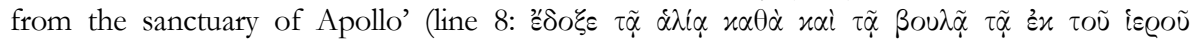

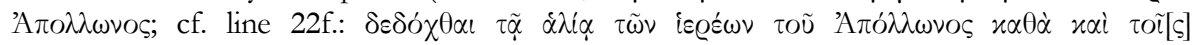

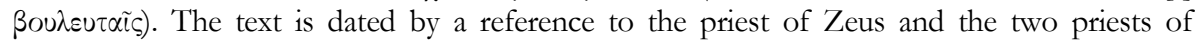
Apollo. The decree honors a certain Nemenios for his benevolence and benefactions towards the 'priests of Apollo' and the 'koinon of the priests of Apollo'. He is to be honored with a bronze statue set up in the sanctuary of Apollo and dedicated to All the Gods. The honorary

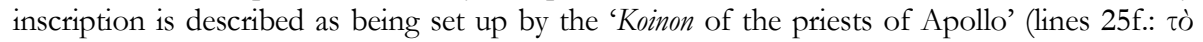

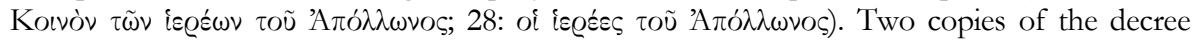
were inscribed on bronze tablets, one given to Nemenios, the other set up in the pronaos of the temple of Zeus in the sanctuary of Apollo. Eight hundred and twenty-five votes were cast in favor of this proposal. See also supra $\mathrm{n}^{\circ} 116$.

178) I. SHopova, “The B $\alpha \chi \chi$ Eĩov from Moesia Inferior", Thracia 18 (2009), p. 201-205 [BE

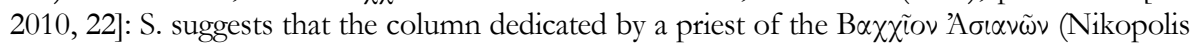
ad Istrum, early 3rd cent. CE; SEG LIII 726.) was placed in the centre of a ritual place as a symbol of the god. She distinguishes between a 'Thracian' Bacchic rite conducted around a column or a free-standing high altar (cf. IGBulg III 1864/1865: $\beta \omega \mu$ ós; I.Perinthos 56: $\tau \varepsilon \lambda \alpha \mu \omega \dot{\nu}$ ) in an open space, and a 'Hellenic' rite, conducted around a Góavov in a specially constructed building (cf. IGBulg V 5579: Góavov) [this interpretation is rejected by M. SĖVE, BE 2010, 22].

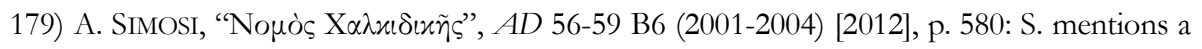
dedication to Asklepios (undated) found re-used in a church on the islet of Ammouliani [originally from the Chalkidike?].

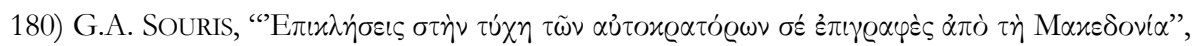
in Kermatia - Touratsoglou II, p. 125-131 [BE 2011, 403]: S. studies the invocation of the emperor's fortune in oaths. Although it is often attested in literary sources and papyri,

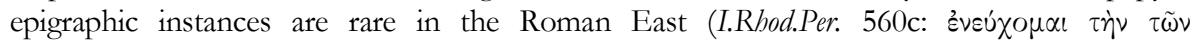

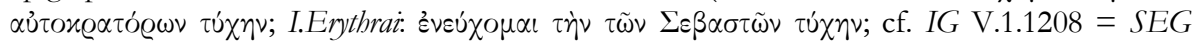

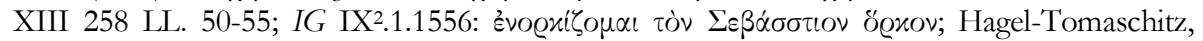

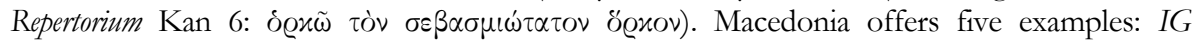

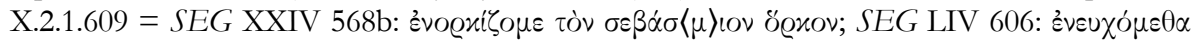

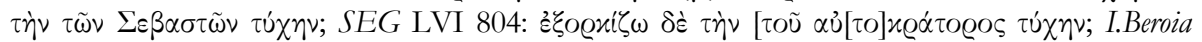

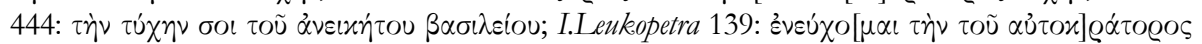
A A $[\tau \omega v \varepsilon i v o u$ Tú] $\chi \eta \nu$, restored by S.). A recently published text from Kalindoia (SEG LIV 606) [EBGR 2004, 251] is one of the earliest examples and the only epigraphic attestation of this formula in the Roman East that concerns the protection of a public building.

181) G. STAAB - G. PetZL, “Vier neue Epigramme aus Lydien”, ZPE 174 (2010), p. 1-14: 1)

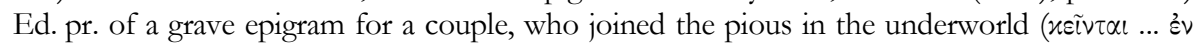

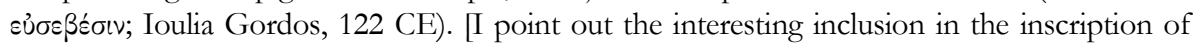
two dates: 2nd Xandikos 204 and 7th Xandikos 206, of the Sullan era. These dates refer to the death of the man and his wife. It follows that the stone was erected at least two years after the death of the individual who died first]. 2) Ed. pr. of a grave epigram for three brothers who died at the ages of 13,11, and 9 (Attaleia in Lydia, 2nd cent. CE). One of them died abroad but his corpse was brought home for burial. The text ends with thoughts about death $(\theta[\alpha] \nu$ iv

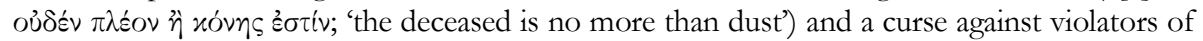

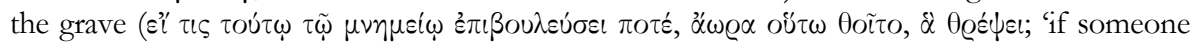
contrives against this memorial, let him too bury the children that he has raised before their time'). 3) Ed. pr. of a grave epigram from Daldis (222 CE) which expresses ideas about the destiny of the deceased young man: 'his parents made this grave for the sake of the best 
memory, so that he is respected also among the dead and tastes the immortal ambrosia from

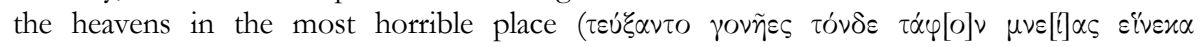

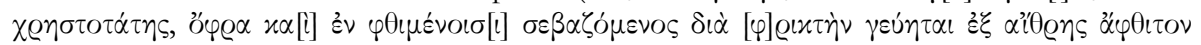
$\dot{\alpha} \mu \beta \varrho O \sigma[i] \eta[v]) .4)$ Ed. pr. of a grave epigram for a doctor (Sardes, undated) [probably 2nd cent. $\mathrm{CE}]$, who is praised for healing eye diseases without interest in profit as well as for knowing that all men must die: 'Du hast, Stratonikos, gut aus deiner Gesinnung heraus gelebt, in der Erkenntnis, daß man alles zurücklassend die Augen schließen muß. Zweimal tot dagegen sind andere, wenn sie dies nicht erkannt haben, was du als Mitgift (sc. in Form eines Grabes) für

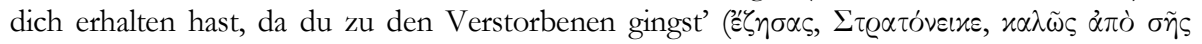

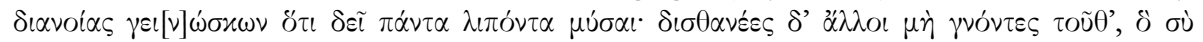

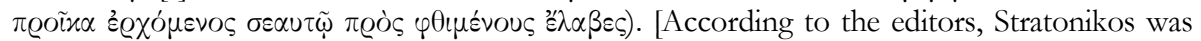
cognizant of the insignificance of material gain; with his lack of avarice, Stratonikos won the gratitude of those who were cured by him and he persisted in their memories. By understanding $\tau \circ \tilde{0} \theta$ ' as a reference to the grave, the editors think that the cause of 'double death' $(\delta\llcorner\sigma \theta \alpha \nu \varepsilon \varepsilon \varepsilon \varsigma)$ is not to receive a grave monument. The editors consider but reject the possibility that $\tau \tilde{0} \tilde{\theta}$ ' refers to the knowledge of the inevitability of death. In my view, Stratonikos' knowledge is not the insignificance of property but, as the text clearly states, the certainty of

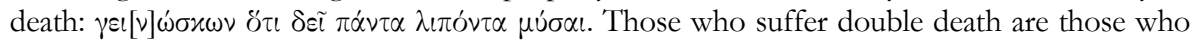
forget this reality. Stratonikos took this knowledge with him to his death, knowledge that one

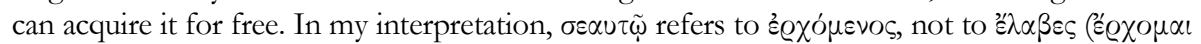
$\tau \iota v^{\prime}=$ 'come to one's aid'). Exactly as Stratonikos assisted others free of charge, he also came to his own aid. 'Stratonikos, you lived well, knowing from your own intellect that one must close his eyes leaving everything behind. Those who do not have this knowledge - which you took for free to the underworld, having come to your own aid' - die twice.] The doctor was

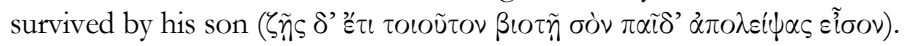

182) E. Stavrianopoulou, "Die Bewirtung des Volkes: Öffentliche Speisungen in der römischen Kaiserzeit", in Ritual Dynamics, p. 159-185 [BE 2012, 144]: S. traces changes in the ritual banquets held in the cities in the Roman East. With the banquet organised by Epameinondas of Akraiphia (IG VII 2712, mid-1st cent. CE) [see supra no 35] as her starting point, S. observes a series of changes as compared to banquets in the earlier periods. Banquets in the Classical and Hellenistic periods were based on the principle of equality in the distribution of food, which the participants were obliged to consume together at the place of the sacrifice. From the 2nd cent. on, and especially in the Imperial period, the sponsors of banquets expanded the circle of invitees in order to include foreigners, the free population of the countryside, slaves, and children (IG XII.7.515; XII.9.234; I.Priene 113; I.Sestos 1; I.Stratonikeia 170 and 1025; IGR V 294); they also impressed the people with extraordinary generosity and unusual offerings (I.Stratonikeia 192, 197, 202, 203, 205, 242, 254-256 295, 309, 672). In organising banquets, the sponsors garnered symbolic capital, strengthened their authority, and reaffirmed hierarchical relations through the different treatment of members of elite families. The banquets of the Imperial period were influenced by Roman practices of cenae publicae.

183) C. STEIMLE, Religion im römischen Thessaloniki. Sakraltopographie, Kult und Gesellschaft, 168 v.Chr.-324 n.Chr., Tübingen, 2008: S. studies the cults that were introduced in Thessalonike after the Roman conquest, from the Late Hellenistic period to the reign of Constantine. A major innovation was the imperial cult (p. 18-23, 31-61, 132-142, 156-158) and the festivals connected with it (p. 158-167; cf. SEG XLIX 815-818). The imperial cult was possibly linked to the cult of Aphrodite (p. 36-47). Another important cult, closely associated with the

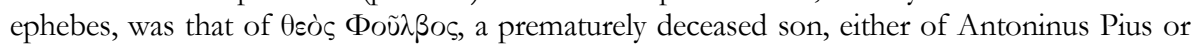
Marcus Aurelius (p. 61-62, 142-156: cf. IG X.2.1.153-170, 236). There is also extensive 
evidence for the cult of Egyptian deities in Thessalonike (p. 79-132; see esp. IG X.2.1.50, 75112 and 259) and some evidence for the cult of Mithras (63-69). S. details the cultic activities of

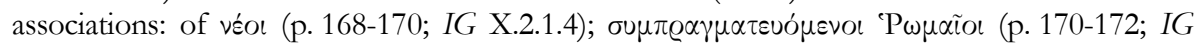

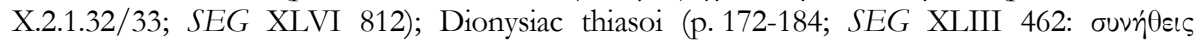

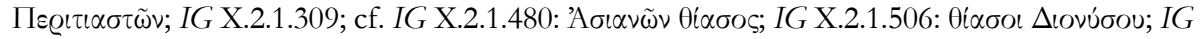

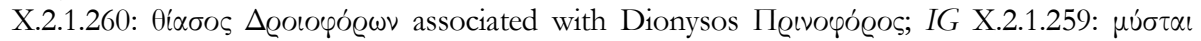

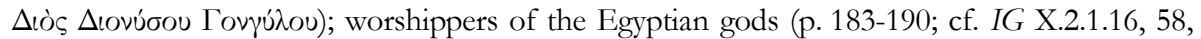

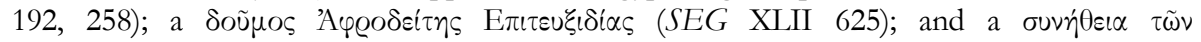

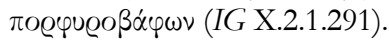

184) M. STEIN, “Zum christlichen Homercento SGO 19/21/02 (IV p. 231 SQ)”, ZPE 174 (2010), p. 57-64: S. discusses an interesting grave epigram of unknown provenance (Paphlagonia, 4th/5th cent. CE; SEG LI 1735; EBGR 2001, 88), which consists of a pastiche of phrases and lines from the Iliad and the Odyssey ('cento'). Of interest are lines 8f., which contain an

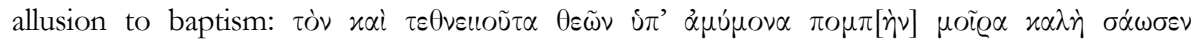

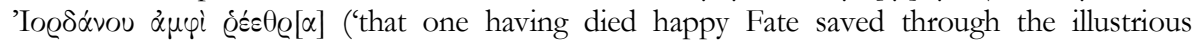
protection of the gods by the waters of Jordan; cf. Il. VII, 135, where the river is 'I $\alpha \varrho \delta \alpha \nu \circ \varsigma)$. S. discusses the adaptation of pagan themes and the reference to 'gods' ( $\theta \varepsilon \tilde{\omega} \nu$ i $\pi$ ' $\alpha \mu u$ uov $\alpha$

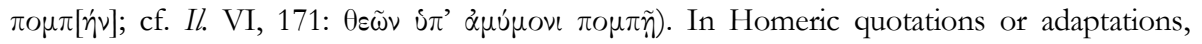
Christian authors sometimes changed the plural to singular (e.g. Eudokia cento I 208, CCG

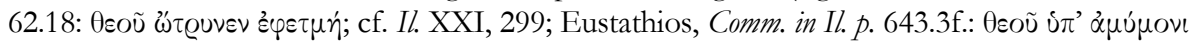
$\pi \mathrm{\rho} \mu \pi \tilde{n})$. However, in the early Christian period, polytheistic formulations are attested (p. 62f.). The epitaph for Ablabios in Rome, certainly a Christian, since the inscription is accompanied by crosses and a christogram, is such an example (ICUR X 27642): $\ddot{\eta} \varrho \omega$ 'A $\beta \lambda \alpha \dot{\beta}$ ıov $\theta \varepsilon o \varepsilon เ \delta \varepsilon ́ \alpha \gamma \tilde{\varepsilon} \alpha$

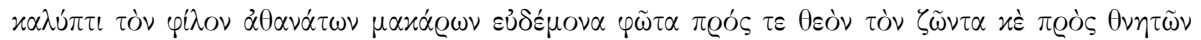

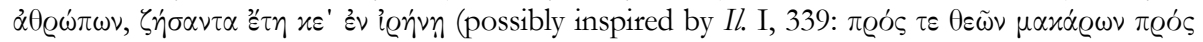
$\tau \varepsilon \theta \nu \eta \tau \tilde{\omega} \nu \dot{\alpha} \theta \varrho \omega \dot{\omega} \pi \omega v)$ ). A refernce to gods is also encountered in ICUR II 4221 (sed breve tempus babet munus quodcumque deorum), which seems to be Christian because of the reference to faith (pietas fider). References to pagan motifs are common in Christian inscriptions (e.g., SGO 22/21/01 1; 16: Maria leads the souls to the place where Rhadamanthys is).

185) G.A. SteinHAuer, “À propos du décret de Rhamnonte en l'honneur d'Epicharès”, in

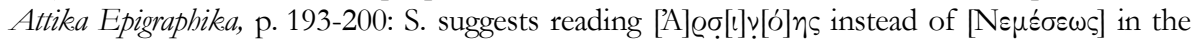
honorary decree for the Athenian general Epichares (SEG XXIV 154, ca. 263); consequently, the sanctuary that he repaired was that of Arsinoe.

186) D. Summa, "Ein Amphiktioniedekret aus Ostlokris. Neues zu 'Le scandale de ca. 117 av. J.-C.”, ZPE 172 (2010), p. 100-104 [BE 2010, 355]. Ed. pr. of a small fragment from Opous (late 2 nd cent.). The preserved words show that it belonged to a copy of the famous dossier of documents concerning the conviction of officials for financial mismanagement of Apollo's sanctuary in Delphi (CID IV 119 A-H). The new fragment contains the votes of the East and West Lokrians and the verdict of the Amphiktyons (the names of the convicted officials and the sums that they had to pay). Thus, this fragment permits a better restoration of the Delphic copy (CID IV 119 H 70-81).

187) B. TAKMER, "Stadiasmus Patarensis için Parerga (2). Sidyma I. Yeni Yazitlara Birlikte Yerleşim Tarihçesi", Gephyra 7 (2010), p. 95-136: Ed. pr. of a dedication to Augustus from Sidyma (1). A new epitaph (6) threatens grave violators with a fine; the violators will be

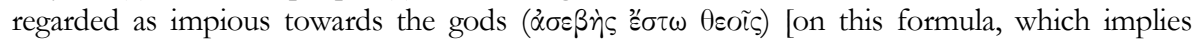
potential divine punishment, see A. DELLI PIZZI, "Impiety in Epigraphic Evidence", Kernos 24 (2011), p. 59-76]. 
188) A. TATAKI, "Nemesis, Nemeseis, and the Gladiatorial Games at Smyrna", Mnemosyne 62 (2009), p. 639-648: The cult of the Nemeseis in Smyrna is attested since the Classical period. In the Imperial period, the contest of the Nemeseia took place in their honor. Indirect evidence suggests that the Nemeseis were associated with the imperial cult and with gladiatorial combats.

189) R. TEKOĞLU, "Some Greek Inscriptions from Antalya", Adalya 7 (2004), p. 217-221 [SEG LIV 1276]: Ed. pr. of a stele decorated with two olive sprays and a lightning bolt and dedicated to Zeus Aizanites ( $\Delta i{ }^{\prime}$ 'E $\zeta \varepsilon \alpha v i$ in; in a private collection, probably from Aizanoi?, 2nd cent. CE). The dedication was made by a man for himself and his family in fulfillment of a vow.

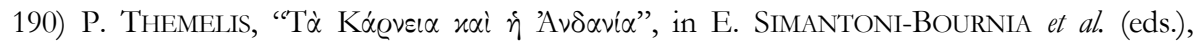

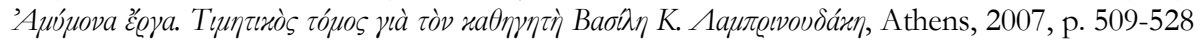
[BE 2011, 280; SEG LVII 372]: T. republishes with detailed commentary a dedication made to

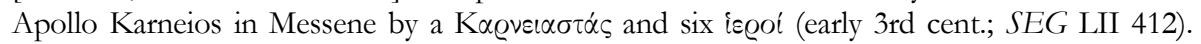
The dedication may have been a statue of the god, possibly represented as a young man with ram's horns. Some of the dedicants may be identified with individuals known from other sources. The Karneiastas (to be distinguished from a Karneonikes, a victor at the Karneia) was a young unmarried man between 20 and 30 years old. T. associates the bieroi with the hieroi of the mysteries of Andania, i.e., initiated men of Messene, who belonged to elite families, represented the five Messenian tribes and were selected by lot in order to officiate in the mysteries [but see supra $\mathrm{n}^{\circ} 155$; interestingly, the number of these men (one Karneiastas plus six hieroi), i.e. seven, is the number usually associated with Apollo]. A list of officials from

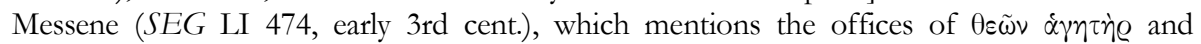
$\pi \varrho o ́ \sigma \pi \circ \lambda \circ \varsigma$, may also be connected with the festival of the Karneia. The plural $\theta \varepsilon \tilde{\omega} \nu$ in the designation $\theta \varepsilon \tilde{\omega} \nu \dot{\alpha} \gamma \eta \tau \dot{\eta} \varrho$ suggests that this official (priest?) was responsible for the cult of a group of gods (Apollo Karneios, Artemis, Hermes, Aphrodite, and others). T. examines the evidence for the mysteries of Andania and presents arguments in favour of dating the cult regulation to $24 \mathrm{CE}$.

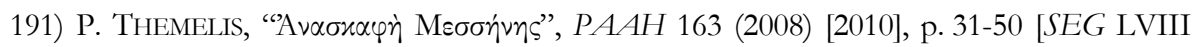
384-385]: In a report on recent excavations at Messene, T. presents several new inscriptions. On a step of the krepis of a temple, north of the temple of Artemis Limnatis, an inscription had already been recorded in 1993 (SEG LIV 383); a new investigation shows that a further word

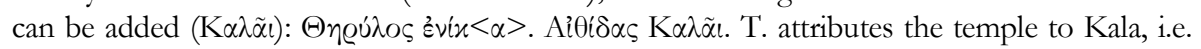
Eileithyia (cf. Paus. IV, 31, 9). To support this interpretation, he adduces IG V.1.1445, a dedication to Eileuthyia and the Kaloi (i.e. the Kouretes; p. 42-44). [To judge from the ph., this is a graffito, not a dedication. Aithidas may just be referring to the female object of his affection: 'Aithidas, for his beautiful one'. The graffito of Therylos and Aithidas, both men, casts doubt on an attribution to Eileithyia]. A fragment of the epistyle of the palaestra is inscribed with a dedication to Hermes and possibly Herakles (1st cent.; p. 48f.).

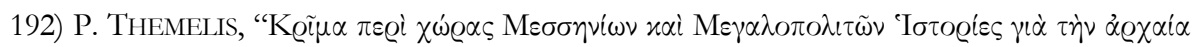
'A@ $\alpha \alpha \delta i \alpha "$, in J.A. PIKOUlas (ed.), Proceedings of the International Symposion in Honour of J. Roy. 50

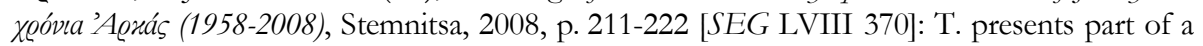
large inscribed stele that contains a Messenian decree (ca. 182). After the successful outcome of a long dispute between Messene, Megalopolis, and the Kaliatai concerning the possession of borderlands (Endania = Andania, Pylana, Akreiatis, Bipeiatis), the Messenians issued a decree with respect to the erection of a stele containing a narrative of the dispute and its outcome. Two pieces of information are of religious significance. The judges visited the Karneiasion (the sanctuary of the Great Gods of Andania) in order to examine the border between Messenia 
and Arkadia; the two-day long trial took place there (lines 36-41). The record was to be inscribed in the sanctuary of Messene. The text provides some topographical information: 'on the base close to the Bouleion, on which the horsemen stand.'

193) S.R. TokHTAS’EV, “A New Curse on a Lead Plate from the North Pontic Region”, ACSS 15 (2009), p. 1-3: Ed. pr. of a defixio on a lead tablet in a private collection (of unknown provenance, from the area of the north shore of the Black Sea, possibly from Olbia, late 4th cent.) [SEG LVII 748]. The tablet was folded in four. It is inscribed with the names of four men.

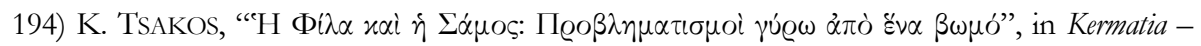
Touratsoglou II, p. 91-105 [SEG LIX 936]: Ed. pr. of a cylindrical altar found in the Hellenistic gymnasion of Samos (late 3rd cent.). Three names are preserved: Epikles, Antigonos (erased), and Phila. Due to the combination of the names Antigonos and Phila, K. tentatively associates the altar with the cult of Demetrios Poliorketes, whose name would have been inscribed on the lost part of the altar, his wife Phila, and their son Antigonos Gonatas. A temenos was dedicated to Phila in Samos (IG XII.6.150). The name Epikles is attested for a prominent Samian family (IG XII.6.172 B 60-62). Since the altar and its inscription cannot be dated earlier than ca. 200 BCE, it cannot have been erected during the reign of these early Antigonids; but it could have been set up during the time when Samos was under the control of Philip V (201 $\mathrm{BCE})$; in that case, the inscription was effaced after the Antigonids lost the island.

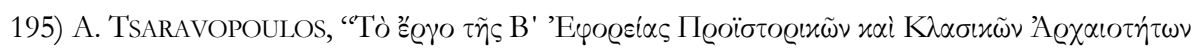

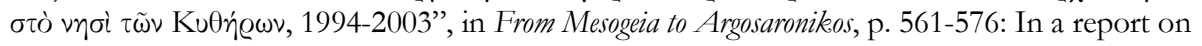
archaeological activities in Kythera, T. mentions several epigraphic finds (no inedita). A clay tablet found in the cult cave of Chousti (in Diakofti) is inscribed with a list of syllables probably a writing exercise (SEG XLIX 386, 4th cent.). [ID., Horos 13 (1999), p. 264-266, had tentatively associated the cave with the cult of Aphrodite and had suggested that the writing exercise was a dedication or was used by candidates for a priesthood. For a similar tablet, unfortunately of unknown archaeological provenance, see SEG LIV 1792. It should be noted that writing exercises, abecedaria et sim. are attested as dedications in Greece, Italy, and Cyprus. A few examples: Acropolis of Athens: SEG XXX 324; Mende, sanctuary of Poseidon: SEG XLII 617; Eretria, sanctuary of Apollo: SEG LV 980(3); Geronisos (Cyprus), sanctuary of Apollo: SEG LVII 1741(3); sanctuary at Punta Stilo (Kaulonia): SEG LVII 931; Veneto: E. Perego, "Engendered Actions: Agency and Ritual in Pre-Roman Veneto", in A. Chaniotis (ed.), Ritual Dynamics in the Ancient Mediterranean: Agency, Emotion, Gender, Representation, Stuttgart, 2011, p. 26-28]. A sanctuary of Asklepios has been identified in the area of the Monastery of St. Theodoros, where a jug dedicated to Asklepios was found (SEG LI 444; EBGR 2004, 284).

196) Y. TzIFopoulos, Paradise Earned. The Bacchic-Orphic Gold Lamellae of Crete, Washington, D.C., 2010: Y. publishes nine gold epistomia (gold leaves placed on the mouth of the deceased during their burial) that contain Orphic texts (3rd cent. BCE-1st cent CE). Except for one new text from Sfakaki (no 9), the other texts from Eleutherna (1-7) and Safaki, north of Rethymnon (8), were already known and have been included in the recent corpora of Orphic texts (cf. EBGR 1998, 89; 2008, 15 and 57). The new text, hitherto known only from preliminary presentations, is very important because it furnishes a new variant of the formula 'but give me to drink from the spring, which the initiates were required to utter when they reached the

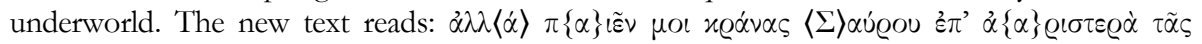

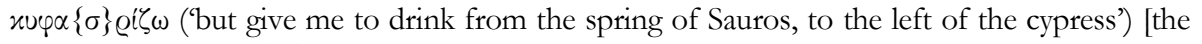

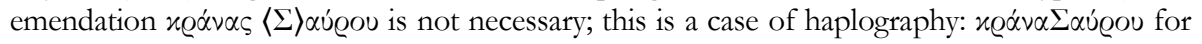

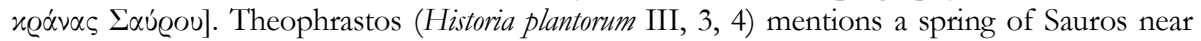
the Idaean Cave, which suggests a connection of the Dionysiac-Orphic community of this part 
of Crete with the Idaean Cave. Sauros can also be associated with Eleutherna's early name Satra or Saoros [the form $\Sigma \dot{\alpha} \tau \varrho \alpha$ possibly originates from an ancient misinterpretation of $\sum \dot{\alpha} F \varrho \alpha$, the digamma being taken for a tau]. In his exhaustive analysis of these texts, T. adduces related epistomia from Macedonia and Byzantine Crete, the Kouretes hymn of Palaikastro, and the metrical lex sacra from the temple of Meter in Phaistos (I.Cret. I.xxiii 3), in addition to literary sources (especially the legends concerning Epimenides and the fragments of Euripides' Kretes), in order to reconstruct the - still unclear - religious context in which the Cretan epistomia were created. He discusses the Dionysiac-Orphic rituals, the archaeological contexts and epigraphic features of the texts, and the possible connections of the Cretan epistomia with the Orphic hieros logos. [Excerpts of this book are now published in ID., "Center, Periphery, or Peripheral Center: A Cretan Connection for the Gold Lamellae of Crete", in R.G. EDMONDS III (ed.), The "Orphic" Gold Tablets and Greek Religion. Further Along the Path, Cambridge, 2011, p. 165-199].

197) G. VALLARINO, "I dedicanti di Cos in età ellenistica: il caso dei magistrati eponimi tra polis

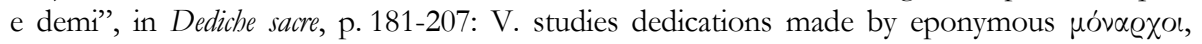

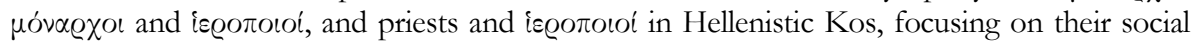
contexts (family relations among the dedicants, social position, motivation). In an appendix, he summarizes in nine tables dedications by magistrates, current and former priests, cult associations, officers, officials responsible for the youth ( $\pi \alpha \iota \delta o v o ́ \mu o l, \pi \alpha \iota \delta \varepsilon v \tau \alpha i$, and

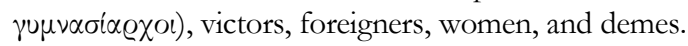

198) B. VAn Oppen, “The Death of Arsinoe II Philadelphus: The Evidence Reconsidered”, ZPE 174 (2010), p. 139-150: After reconsidering the epigraphic and papyrological evidence, the author argues that Arsinoe II Philadelphos died in 268, not 270 BCE; her cult was not implemented posthumously but had already been established in her lifetime and was independent of that of Ptolemy II, her husband and brother.

199) H.S. VerSNEL, Fluch und Gebet: Magische Manipulation versus religiöses Flehen? Religionsgeschichtliche und hermeneutische Betrachtungen über antike Fluchtafeln, Berlin, 2009: The distinction between curses and 'prayers for justice' has attracted a great deal of interest in recent discussions of religious mentality [see EBGR 1991, 261; 2002, 54; 2004, 44, 45, and 128; 2006, 15, 69, and 76; 2007, 16, 49; 2009, 31]. In his book, V. presents the main arguments in favour of this distinction and summarizes his research on this topic. Drawing upon the evidence of a large number of texts, he gives an overview of the main features of binding spells, their formulae, and their aims (p. 4-14). Unlike defixiones, prayers for justice, such as the Knidian texts (I.Knidos 148 and 150) and another from Amorgos (IG XII.7 p. 1), are requests for justice; they are found in sanctuaries, not in graves; the great power of the divinities is praised; the authors appeal to the gods with emotional phrases and words of pleading that differ from voces magicae; the texts have a public character and were probably accessible to readers; the authors often supply their names and some sort of justification (p. 14-25). Whereas defixiones appear as early as the 6th cent. in Greece, the first large group of prayers for justice is encountered in the Hellenistic period; the initial appearance of such texts in Asia Minor, their social context, and their similarity to petitions and 'confession inscriptions' (e.g. BIWK 69) signals an influence from the Near East and Egypt (p. 25-37). Conversely, there is limited evidence for appeals for divine justice in everyday life in Archaic and Classical Greece, although oracular enquiries, e.g. from Dodona, request that the gods reveal the culprit (p. 37-40). Finally, there are also 'mixed forms', i.e. curses combined with references to the fact that the defigens was a victim of injustice. [For a different view see M. DREHER, “Gerichtsverfahren vor den Göttern? - 'Judicial Prayers' und die Kategorisierung der defixionum tabellae", in G. THÜR (ed.), Symposion 2009. Vorträge zur griechischen und bellenistischen Rechtsgeschichte (Seggau, 25.-30. August 2009), Vienna, 2010, p. 301- 
335; Dreher's study will be presented together with other relevant studies in the next issue of the EBGR. See also supra n ${ }^{\circ}$ 96].

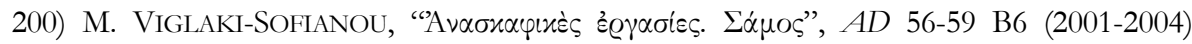
[2012], p. 39-41 [SEG LIX 937]: An inscribed base of an Ionic column was found at the Pythagoreion (Samos, undated) [probably Hellenistic]. The text reports that a man made a

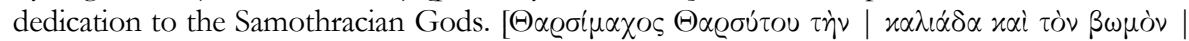

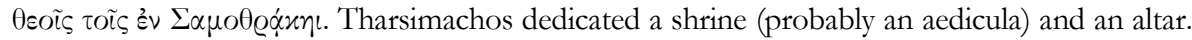
$K \alpha \lambda i \alpha \varsigma$ is often mentioned in ancient inventories, designating a container; e.g. IG II 1424 line

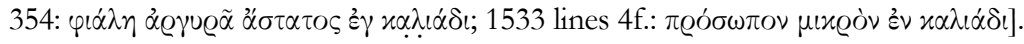

201) G.P. VISCARDI, “Artemide Munichia: aspetti e funzioni mitico-rituali della dea del Pireo", DHA 36.2 (2010), p. 31-60: V. explores the various mythical and cultic aspects of the cult of Artemis Mounychia in Piraeus, one of the most prominent Athenian cults. Sacrifices took place in the homonymous tenth month (Mounychion) of the Attic calendar, and a specific cake with small torches (amphiphon) was deposited for her (and Hekate) on street intersections on days when the rising sun and the setting moon were concurrently visible. This cult was associated with the commemoration of the Greek victory in the Battle of Salamis (cf. $\ddot{\alpha} \mu \nu \lambda \lambda \alpha$ $\pi \lambda$ ii $\omega \nu$ in Mounychia: IG II² 1006 lines 29f.; 2130 lines 48f.; SEG XIX 219; XLI 137, etc.). Artemis Mounychia and the hero Mounychos also played an important role in the institution of the ephebeia and ephebic patrol duty. Based on Artemis' epithets (especially Phosphoros; see Xen., Hell. 2.4.10-12), V. suspects that Artemis Mounychia was associated not only with Hekate but also with Ennodia Pheraia and Bendis.

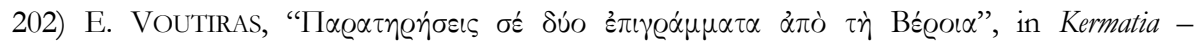
Touratsoglou II, p. 34-45 [BE 2011, 410]: V. presents a new critical edition and commentary of a dedicatory epigram written on a pillar that supported a statue of Pan (Beroia, late 3rd cent.; I.Beroia 37; SEG XLVII 893: see EBGR 1997, 294). According to V.'s interpretation, the dedicant, Hippokles, received a donation of land for pasturage, exempt from all taxes, from the Macedonian king Philip V, still a minor (229 BCE), and Antigonos Doson, the king's guardian. The pillar on which the epigram is inscribed may have been part of a complex structure supporting a statue of Pan and was erected at the entrance to the property that Hippokles had received as a gift. Hippokles worshipped Pan in observance of an ancestral tradition (line 4).

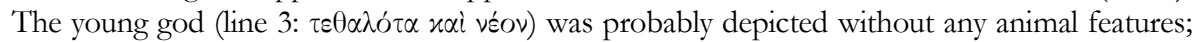

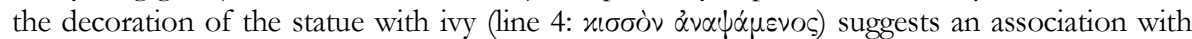
the cult of Dionysos. In the first lines, Pan states that he is worshipped greatly in Arkadia but a 'strong desire brought me like a favourable wind to Macedonia, as her ally' ( $\pi$ ó $\theta$ oৎ $\mu \varepsilon \pi v \varepsilon \tilde{u} \mu \alpha$

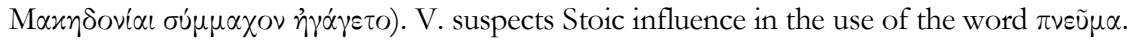

203) J. WALlensten - J. PAKKanen, "A New Inscribed Statue-Base from the Sanctuary of Poseidon at Kalaureia”, OpAth 2 (2009), p. 155-165 [BE 2011, 59]: Ed. pr. of an inscribed base from the sanctuary of Poseidon in Kalaureia (ca. 270-246). The inscription commemorates the dedication of a statue of Ptolemy II and Arsinoe to Poseidon by the city of Arsinoe (i.e. Methana). The city chose this sanctuary for the erection of the statue because of its prominence.

204) M. WeBER, "Lumpen für Artemis Brauronia? Zum Wortgebrauch von xalvóv, @́́x xoৎ in den Inschriftentafeln des Brauronions auf der Akropolis in Athen”, Thetis 1617 (2010), p. 39-42 [BE 2011, 81]: W. expresses doubts as to whether the word @ $\alpha$ ros, found in inventories of dedications to Artemis Brauronia, designates a lump. The dedication of @́x ry may be associated with the custom of dressing the cult statues. 
205) U. WeBER, "Eine neue Orakelinschrift aus Didyma zum Kult der Horen in der späten Kaiserzeit", MDAI(I) 58 (2008), p. 243-260 [SEG LVIII 1301]: Ed. pr. of an inscription from Didyma that contains an oracular consultation submitted by the prophet Agathon to Apollo of Didyma (3rd cent. CE). The first lines contain Agathon's question, which is partly preserved. The prophet mentions an altar of the Horai and an inscription: [-- $\left.\beta \omega \mu--\tau \tilde{\omega} \nu{ }^{c} \Omega \varrho\right] \mid \tilde{\omega} \nu x \alpha \tau \varepsilon \lambda \lambda[-$

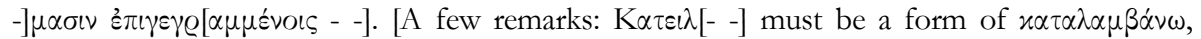
which in this context may have the meaning 'to comprehend' (e.g. IG V.1.1145 lines 35-37: $\delta$

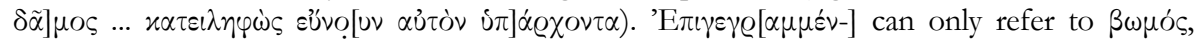

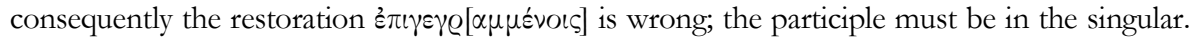
The meaning could be that the altar was inscribed with an old inscription (e.g. [aexaiors

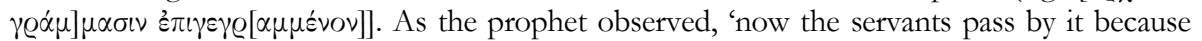

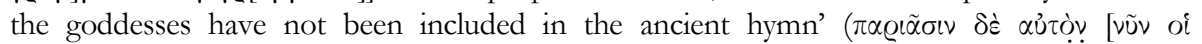

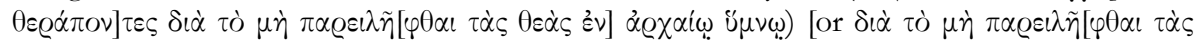

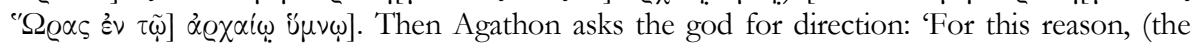
prophet) requests that you reveal whether the goddesses like the custom of embracing this

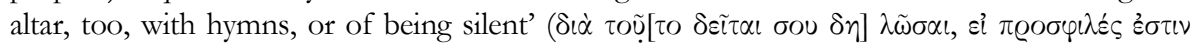

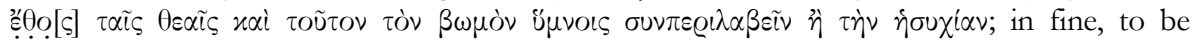
understood as $\hat{\eta} \tau \dot{\eta} \nu \dot{\eta} \sigma u x i \alpha \nu \not \alpha \gamma \varepsilon v)$. W. observes that this is the first attestation of the cult of the Horai in Didyma. It is not uncommon in Didyma that the prophet requested an oracular response. Another oracle of Apollo in Didyma concerns a neglected altar, that of Tyche (W. GÜNTHER, "Inschriften", $M D A I(I)$ 21, 1971, p. 97-108, n I). The Horai are regarded metaphorically as the mothers of the hopes, the 'undying children', because of their association with the seasonal fruits of nature. The cult of the Elpides is attested in Miletos only in the later part of the Imperial period ( 256 n. 51). The god's response, composed in verse and using a rare vocabulary, grants permission for the inclusion of the Horai in the hymn: $\dot{\eta} \mu \varepsilon \tau \varepsilon e \eta \varsigma ~ o ́ \mu \varphi \tilde{\eta} s$

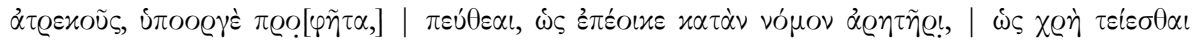

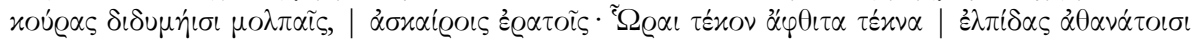

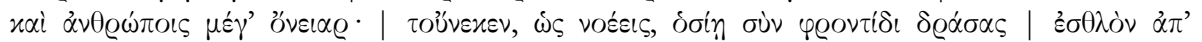

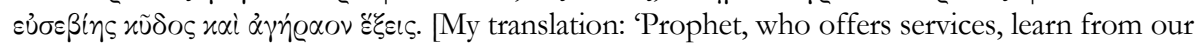
accurate voice, as is appropriate to a priest in accordance with the custom that one should honor the girls with double song and lovely dances. The Horai gave birth to undying children, the hopes - great help for both immortals and men. For this reason, if you act piously, as you have in mind, you shall have noble and undecaying glory'. This translation differs in one point from that of W.: he translates $\delta \varrho \alpha ́ \alpha \alpha \varsigma$ with 'opferst' ('sacrifice'). This is, in principle, possible

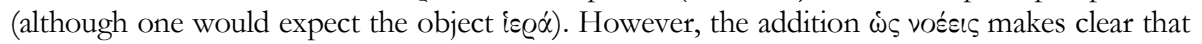
the god refers to Agathon's plan, which was to honor the Horai with hymns and not with sacrifices. Of course, an offering must have been made on the altar of the Horai, but there is no evidence that these offerings were blood sacrifices. On the contrary, the new text corresponds to a general trend in the Imperial period to replace sacrifice with the offering of hymns, or to give priority to hymns. For examples, see S. BRADBURY, "Julian's Pagan Revival and the Decline of Blood Sacrifice", Phoenix 49 (1995), p. 331-356; A. CHAnIOTIS, "Old Wine in a New Skin: Tradition and Innovation in the Cult Foundation of Alexander of Abonouteichos", in E. DABROWA (ed.), Tradition and Innovation in the Ancient World, Krakow, 2002, p. 76f.].

206) M.L. WEST, "Rhapsodes at Festivals", ZPE 173 (2010), p. 1-13: W. studies the context of the performances of rhapsodes in festivals. The pre-Hellenistic evidence is limited. Competitions are attested at the Panathenaia (IG II ${ }^{2}$ 2311), the Artemisia in Amarynthos (IG XII.9.189 lines 15-20), and the Asklepieia of Epidauros (Plato, Ion 530a), and possibly, through the indirect evidence of tripod dedications in Dodona, for the Naia (L. ROBERT, Collection Froeher. 
Inscriptions grecques, Paris, 1936, no. 39; SGDI 5786; cf. SEG XLVI 2312). There is also evidence for recitations of the Iliad at the Brauronia (Hesychios $\beta$ 1067) and in Syracuse, at the court of Dionysios I (Diod. XIV, 109, 1f.). There must have been also opportunities at festivals outside the organized program. The bulk of the evidence is from the Hellenistic period and mostly from Boiotia. In victor lists, the victorious rhapsode is often preceded or followed by an epic poet. From this, W. infers that the rhapsodes presumably recited the competing poets' new poems, and that there was one prize for the best poem and another for the best performance. There were recitations outside of the competitions (Delos: IG XI.2.105; Koresia: IG XII.5.647 line 35). Competitions took place at the Erethimia in Rhodes (V.N. KONTORINI, "Les concours des Grands Eréthimia à Rhodes", $B C H$ 99, 1975, p. 102 fr. B), the Amphiktyonic Soteria (SEG I 187a; XVIII 230, 235; SGDI 2563-2566) and the Aitolian Soteria at Delphi (SEG II 260; F.Delphes III.4.125-128), the Artemisia in Amarynthos (IG XII.9.139), a festival in Chios (Syll.3 959) and in a large number of Boiotia festivals (Mouseia: I.Thespiai 163, 170-172; Rhomaia: SEG LIV 516-517; Amphiaraia Rhomaia: I.Oropos 523-524, 526, 528; Charitesia: IG VII 3195-3197; Ptoia: 4147; Soteria: IG VII 2727; Sarapieia: IG VII 540) [on these festivals see supra $\left.\mathrm{n}^{\circ} 118\right]$. In the Imperial period, rhapsodic contests are only attested, probably after an interruption, in Boiotia (Mouseia: I.Thespiai 178-179; Ptoia: IG VII 2726, 4145; Ptoia Kaisareia: L. BIZARD, "Une inscription du sanctuaire d'Apollo Ptoïos trouvée à Larymna", BCH 27, 1903, p. 296-299, A 12). Two poets are designated as rhapsodes in their epitaphs in Argos (IG IV 649) and Salamis (Salamine XIII 272B). As regards the function of P. Aelius Pompeianus

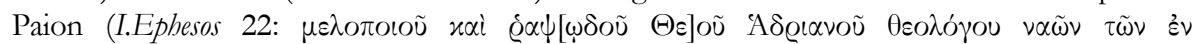

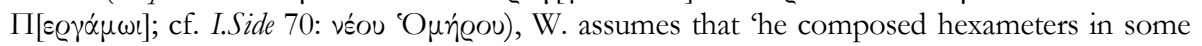
quantities, though not necessarily at epic length: perhaps encomia which, in his guise as "rhapsode", he also recited. His poetic victories had no doubt been won in more prestigious arenas than Boeotian local festivals. His talents as a $\mu \varepsilon \lambda o \pi o t o ́ \varsigma$ and declaimer of poetry had evidently received official recognition from Hadrian' [for a different interpretation see supra no 61]. To demonstrate the rhapsodes' mobility, W. presents a list of rhapsodes who performed in a city other than their own or who won victories in more than one place (p. 12). For a few additions and corrections see ID., "Rhapsodes at Festivals: Addenda", ZPE 174 (2010), p. 32.

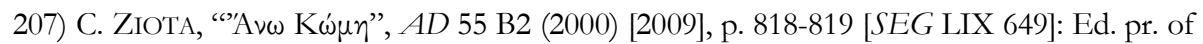
an interesting votive relief found at Ano Komi Kozanis (Macedonia, 2nd/3rd cent.). The relief features a male figure (Zeus Hypsistos?) standing next to an altar supporting a column. The relief was dedicated to Zeus Hypsistos by Andronikos. [The text, only partly read by Z., reads:

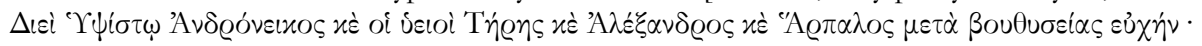

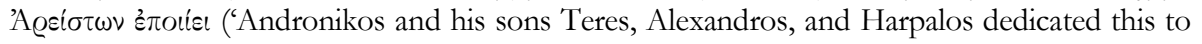
Zeus Hypsistos, together with the sacrifice of an ox, in fulfilment of a vow')]. Two other votive reliefs, dedicated to Hera ( $E A M$ 81, Ano Komi) and Artemis Agrotera (EAM 101, Spilia Eordaias), were the works of the same artist.

Angelos CHANIOTIS

School of Historical Studies

Institute for Advanced Study

Einstein Drive

Princeton, NJ 08540

E-mail:achanioti@ias.edu 